
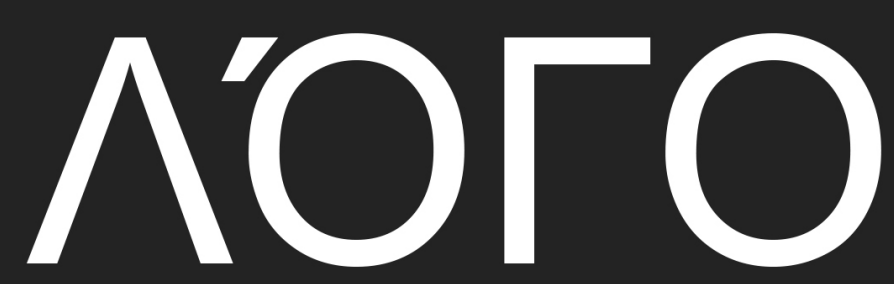

COLLECTION DE PAPIERS SCIENTIFIQUES

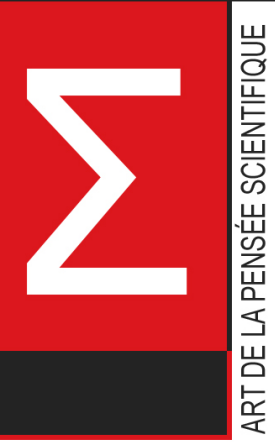

SUR LES MATÉRIAUX DE LA CONFÉRENCE SCIENTIFIQUE ET PRATIQUE INTERNATIONALE

\title{
PROBLÈMES ET PERSPECTIVES D'INTRODUCTION DE LA RECHERCHE SCIENTIFIQUE INNOVANTE
} 29 NOVEMBRE 2019 • BRUXELLES, BELGIQUE —

\section{VOLUME 4}

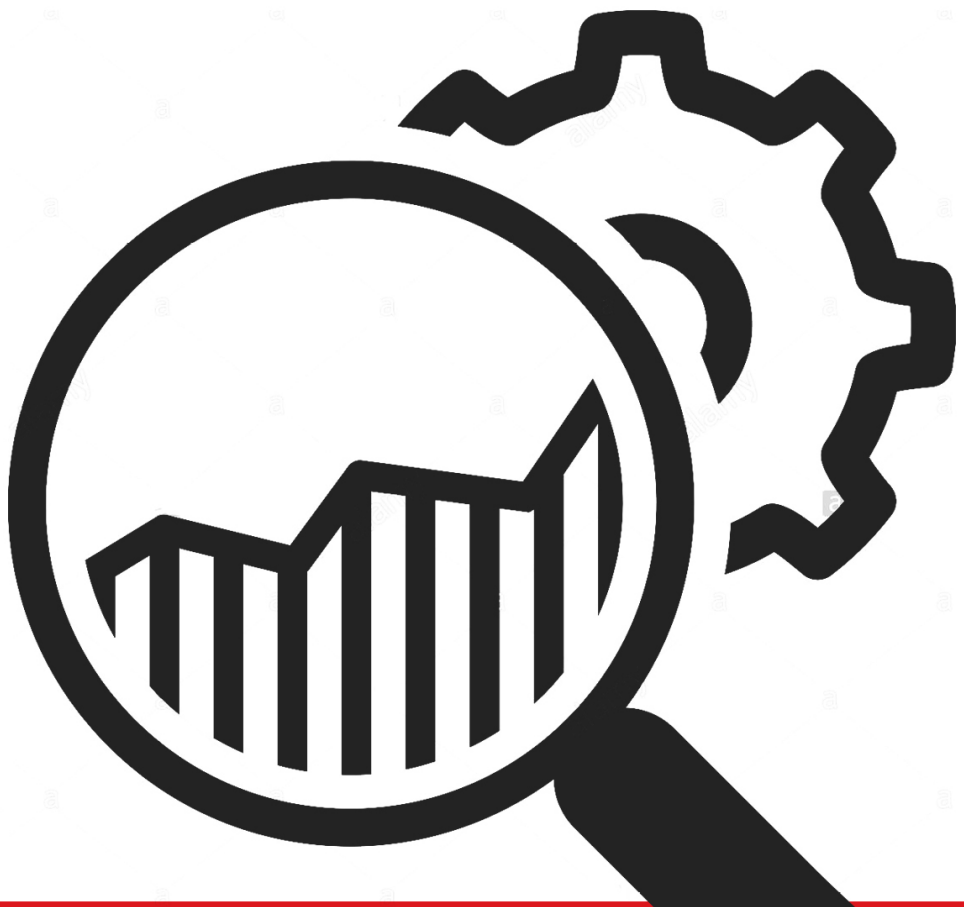



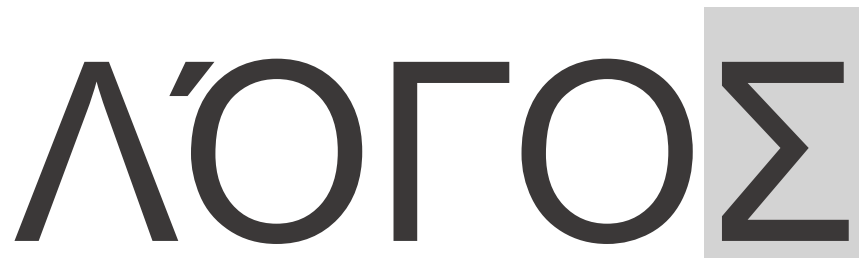

COLLECTION DE PAPIERS SCIENTIFIQUES

SUR LES MATÉRIAUX DE LA CONFÉRENCE SCIENTIFIQUE ET PRATIQUE INTERNATIONALE

«PROBLÈMES ET PERSPECTIVES D'INTRODUCTION DE LA RECHERCHE SCIENTIFIQUE INNOVANTE»

29 NOVEMBRE 2019

\section{VOLUME 4}


P 93

Président du comité d'organisation: Holdenblat M.

Responsable de la mise en page: Kazmina $N$.

Responsable de la conception: Bondarenko I.

P 93 Problèmes et perspectives d'introduction de la recherche scientifique innovante: collection de papiers scientifiques

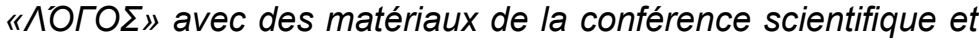
pratique internationale (Vol. 4), 29 novembre, 2019. Bruxelles, Belgique: Plateforme scientifique européenne.

ISBN 978-617-7171-89-7

DOI 10.36074/29.11.2019.v4

Les résumés et articles des participants à la conférence multidisciplinaire scientifique et pratique internationale «Problèmes et perspectives d'introduction de la recherche scientifique innovante», qui s'est tenue à Bruxelles le 29 novembre 2019, sont présentés.

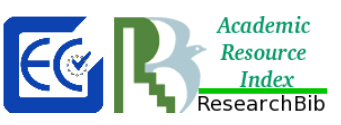

L'événement est inclus dans le catalogue des conférences scientifiques internationales, approuvé sur la plate-forme ResearchBib et certifié par Euro Science Certification Group norme scientifique SCC-2000.

Les documents de la conférence sont disponibles au public sous licence Creative Commons Attribution 4.0 International (CC BY 4.0).

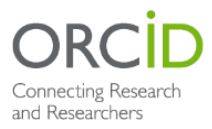

and Researchers

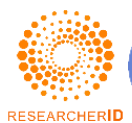

RESEARCHERID
La description bibliographique des documents de la conférence peut être téléchargée et indexée dans ORCID, Publons, Google Scholar, etc. 


\section{CONTENU}

\section{SECTION VIII. SCIENCES PHARMACEUTIQUES}

TREATMENT OF ANGINA PECTORIS BY MEDICINAL PLANTS AND PHYTOMEDICINES

Research group:

Stoletov Yu., Kutsenko T., Ulanova V., Belik G. 7

\section{SECTION IX. \\ SCIENCES PSYCHOLOGIQUES ET SOCIOLOGIQUES}

MAIN CHARACTERISTICS OF REFLECTIONAL EDUCATION ENVIRONMENT

Yashnyk S. 9

PSYCHOLOGICAL ASPECTS OF THE STRUGGLE FOR TRUTH

Rubskyi V.

АДАПТАЦІЯ ШКАЛИ ФРЕНСІСА «АФЕКТИВНЕ СТАВЛЕННЯ ДО ХРИСТИЯНСТВА» (FRANCIS SCALE OF ATTITUDE TO CHRISTIANITY») УКPAÏHСЬКОЮ МОВОЮ

Коваленко Ю.В.

АНАЛІЗ СОЦІАЛЬНО-ПСИХОЛОГІЧНИХ ПРИЧИН АГРЕСІЇ В ПЕДАГОГІЧНОМУ СЕРЕДОВИЩІ

Косило Х.M.

АНАЛІЗ СУЧАСНИХ ПОГЛЯДІВ НА ЕМОЦІЙНУ СФЕРУ ОСОБИСТОСТІ

П'янківська Л.В.

ДІАГНОСТИКА ДОМІНУВАННЯ НАВЧАЛЬНИХ АБО ІГРОВИХ МОТИВІВ ДО НАВЧАННЯ В ШКОЛІ

Чекстере О.Ю.

ОСОБЛИВОСТІ ПОВЕДІНКИ ВАЖКОВИХОВУВАНИХ ПІДЛІТКІВ ТА ШЛЯХИ ІЇ̈ КОРЕКЦІї

Яшник С.В., Верхуша Ю.С.

ПСИХІЧНА КУЛЬТУРА ЯК ДИНАМІЧНЕ УТВОРЕННЯ ПРИ ПРОФЕСІЙНОМУ СТАНОВЛЕННІ МАЙБУТНЬОГО ФАХІВЦЯ МОРСЬКОГО ТРАНСПОРТУ

Сорока О.M.

ПСИХОЛОГИЧЕСКИЕ ПОДХОДЫ К ИЗУЧЕНИЮ САМООЦЕНКИ 
4 - Problèmes et perspectives d'introduction de la recherche scientifique innovante $\bullet$ Volume 4

ЛИЧНОСТИ

Масловская О.В. 32

СІНЕМАЛОГІЯ ЯК МЕТОД ФОРМУВАННЯ ЖИТТЕСТІЙКОСТІ ПІДЛІТКІВ

Казьмірук А.B. 37

СКЛАДОВІ ЖИТТЕВОГО УСПІХУ ОБРАЗІВ ВІДОМИХ ОСОБИСТОСТЕИ

Носова О.В.

\section{SECTION $X$.}

COMMUNICATIONS SOCIALES ET CULTURE

L'IMPACT DU TOURISME GASTRONOMIQUE SUR LA FORMATION DES DERNIERES TENDANCES DU TOURISME CULTUREL

Ditchkovski S., Ivanov S.

ВИКЛИКИ ДУАЛЬНОЇ ОСВІТИ: РОЗРОБКА СТРАТЕГІЇ НАВЧАННЯ (НА ПРИКЛАДІ ІВЕНТ-МЕНЕДЖМЕНТУ, КНУКІМ)

Пархоменко I.I.

ВИКОРИСТАННЯ СУЧАСНИХ ІННОВАЦІЙНИХ ТЕХНОЛОГІЙ У ПІДГОТОВЦІ ФАХІВЦІВ 3 ІНФОРМАЦИЙНОЇ, БІБЛІОТЕЧНОЇ ТА АРХІВНОÏ СПРАВИ

Ткаченко Д.В.

ВПЛИВ ТУРИЗМУ ТА ПРОМИСЛОВОЇ ДІЯЛЬНОСТІ НА ТУРИСТИЧНІ РЕСУРСИ СВITУ

Нестерук M.I.

ІСТОРІЯ КОНСЕРВАЦІЇ ТА РЕСТАВРАЦІЇ ДОКУМЕНТІВ

Жданова Л.О.

СУЧАСНИЙ ОФІС: ТРАДИЦІЇ ТА НОВАТОРСТВО

Сорокова A.O.

СУЧАСНІ ПІДХОДИ ДО СТВОРЕННЯ КОМФОРТУ У ЗАСОБАХ РОЗМІЩЕННЯ

Нестерук М.I.

SECTION XI.

SCIENCES PEDAGOGIQUES

DEVELOPMENT OF FUTURE ENGINEERS' PROFESSIONAL COMMUNICATIVE COMPETENCE AT ESP CLASSES

Research group:

Goncharenko T., Dyomochka L., Durnyeva M. 
DIGITALIZATION AS INEVITABLE VECTOR OF THE EDUCATIONAL SYSTEM DEVELOPMENT IN GERMANY

Dzhurylo A.

IMPLEMENTING BLENDED LEARNING FOR STUDENT SUCCESS

Kruk A.

INNOVATIONS IN THE FIELD OF FOREIGN LANGUAGES TEACHING

Sarnovska N.

INTERACTIVE ENGLISH LANGUAGE TEACHING

Nikitina $\mathbf{N}$.

LEGISLATIVE PROVISION OF PRIMARY SCHOOL TEACHER TRAINING IN THE BENELUX COUNTRIES AND UKRAINE

Holovatenko T.

MUSICAL THERAPY AS A MEANS OF CORRECTION OF PSYCHOPHYSICAL DISORDERS OF CHILDREN

Tsuranova O., Polynko Ya.

REFERENCE RESOURCES WHEN ORGANIZING STUDENTS' INDEPENDENT WORK

Karasyova 0.

THE FACTOR OF TEACHER'S PERSONALITY ON INCREASING INTEREST OF THE STUDENTS IN HISTORY LESSONS

Kamolov I., Ergasheva M.

VISUAL AIDS AS SUPPORT FOR THE COMMUNICATIVE COMPETENCY

Kozlova 0.

АНАЛІЗ ОСНОВНИХ ПЕРЕВАГ ВИКОРИСТАННЯ МОБІЛЬНИХ ЗАСТОСУНКІВ ПІД ЧАС НАВЧАЛЬНОГО ПРОЦЕСУ

Тищенко М.А.

ВИКОРИСТАННЯ ТЕКСТІВ ПІСЕНЬ БРИТАНСЬКОЇ СПІВАЧКИ АДЕЛЬ НА ПРАКТИЧНИХ ЗАНЯТТЯХ ІЗ «СТИЛІСТИКИ АНГЛІЙСЬКОЇ МОВИ»

Гурський І.Ю.

ВОЗМОЖНОСТИ ИСПОЛЬЗОВАНИЯ ПРОБЛЕМНОГО ОБУЧЕНИЯ В ПРОЦЕССЕ ИЗУЧЕНИЯ ИМЕНИ СУЩЕСТВИТЕЛЬНОГО

Кон О.O.

ВПРОВАДЖЕННЯ ІННОВАЦІЙНИХ ТЕХНОЛОГІЙ НА ЗАНЯТТЯХ ОХОРОНИ ПРАЦІ

Дусматова О.В.

ДО ПРОБЛЕМ ОРГАНІЗАЦІЇ ОСВІТНЬОГО ПРОЦЕСУ НА УРОЦІ 
6 • Problèmes et perspectives d'introduction de la recherche scientifique innovante $\bullet$ Volume 4

ХОРЕОГРАФІЇ

Алтухов В.А.

ЗАСТОСУВАННЯ МІЖКУЛЬТУРНОГО ПІДХОДУ У ПРОЦЕСІ ВИВЧЕННЯ ІНОЗЕМНОÏ МОВИ

Попсуй А.B.

ЗМІНИ В ОРГАНІЗАЦІЇ НАВЧАЛЬНОГО ПРОЦЕСУ ТРУДОВІЙ ШКОЛІ УКРАЇНИ НА ПОЧАТКУ 20-РОКІВ ХХ СТОЛІТТЯ

Великдан Ю.В.

ІНДИВІДУАЛЬНИЙ ПІДХІД ДО СТУДЕНТА ЯК ЗАПОРУКА ЕФЕКТИВНОЇ ПІДГОТОВКИ СТУДЕНТІВ ЗАКЛАДІВ ВИЩОЇ ОСВІТИ Полець М.-В.Я. 


\section{SECTION VIII. \\ SCIENCES PHARMACEUTIQUES}

\section{TREATMENT OF ANGINA PECTORIS BY MEDICINAL PLANTS AND PHYTOMEDICINES}

RESEARCH GROUP:

Stoletov Yu. $\mathrm{PhD}$ in Biology, associate professor at pharmacology department National University of Pharmacy

Kutsenko T.

$\mathrm{PhD}$ in Pharmacology, associate professor at pharmacology department National University of Pharmacy

Ulanova V.

$\mathrm{PhD}$ in Pharmacology, associate professor at pharmacology department National University of Pharmacy

Belik G.

$\mathrm{PhD}$ in Pharmacology, associate professor at pharmacology department National University of Pharmacy

UKRAINE

Angina pectoris (AP) is one the most widespread chronic diseases in Ukraine. The treatment of AP is an important task for now, because its complications lead to death very often. The analysis of the marker of total mortality in Ukraine shows that the diseases of cardio-vascular system, including AP, result in letal outcome in $60 \%$ of patients [1, 2].

There is a great amount of medicines for AP treatment. A lot of them are ones of synthetic origin. These medicines are very effective, but, in the same time, they have disadvantages, for example, high price, marked side effects, etc [3, 4].

It is known, that medicinal plants are unable to be used instead of synthetic antianginal agents. But they may be used as a very good supplement of the anti-anginal therapy, especially in early stages of the disease. Besides, application of medicinal plants is correct and useful for prevention of AP. So, medicinal plants, that may be used for AP treatment, are widely used by folk medicine and several ones of them are also used by official medicine. For example, the latters are Crataegus sanguinea, Valeriana officinalis, Convallaria majalis, Digitalis lanata, Mentha piperita, Leonurus quinquelobatus, Adonis vernalis, etc. The complex of biologically active substances (BAS) of named plants includes cardiac glycosides, flavonoids, alkaloids, cumarins, organic acids, vitamins, macro- and microelements. This complex of BAS cause cardiotonic, spasmolytic, anticoagulant, diuretic, sedative, vasodilative and hypotensive effects $[4,5,6,7]$.

All of these pharmacological effects correspond to the main strategies of AP treatment, such as: improvement of blood supply of myocardium, dilation of blood 
vessels (especially, coronary ones), correction of blood pressure, normalization of blood coagulation, normalization of water-salt metabolism,sedation [2, 4].

It is important to take into account that medicinal plants start to act slowly, their effects come gradually, but may last for a long time $[2,3,7]$.

To our point of view, the perspective direction of treatment and prevention of AP is use of medicines, obtained from the complex of BAS, extracted from the medicinal plants that are approved by clinical practice already or are used just by ethnomedicine only.

In this context the use of Crataegus is well-known. Flowers, fruit and leaves of Crataegus (containing tritherpen saponins, flavonoids, organic acids, trimethylamine, aesculin glycoside, etc.) are used in medicine. Nowadays, phytomedicines, obtained from this plant, are used by official medicine both in our country (preparation Cratal contains extract of Crataegus fruit) and abroad (extract of Crataegus WS $®$ 1442). Named medicines cause cardioprotective and antiarrhythmic effects, improve blood circulation in coronary vessels, increase the myocardial contractility. They are used for treatment of AP, chronic heart failure, etc $[4,6,8,9]$.

Besides this, it is known, that in folk medicine there are many medicinal plants, causing therapeutic effect in AP, such as Viburnum opulus, Linum usitatissimum, Arnica montana, Astragalus dasyanthus, Betula alba, Viscum album, Fragaria vesca, Melilotus officinalis, etc. Most of them are able to affect on the several links of AP pathogenesis in the same time. That is why, extraction and study of BAS from these perspective plants is interesting and important $[2,3,4,5,6,7]$.

Thus, application of phytotherapy for AP treatment is substantiated and has practical value. The creation of new anti-anginal agents of plant origin is expedient and may improve the results of AP therapy.

\section{References:}

1. Сиренко, Ю. (2004). Диагностика, профилактика и лечение артериальной гипертонии. Ліки України. (1), 6-9.

2. Гажев, Б. Н., Виноградова, Т. А., Мартынов, В. К. \& Виноградов, В. М. (1996). Лечение атеросклероза и ишемической болезни сердиа. СПб: ИКФ «МиМ экспресс».

3. Лавренов, В.К. \& Лавренова, Г.В. (2009). Современная энциклопедия лекарственных растений. Москва: ЗАО «ОЛМА Медиа Групп».

4. Кукес, В.Г. (ред.) (1999). Фитотерапия с основами клинической фрармакологии. Москва: Медицина.

5. Рыжская, В. (2010). 100 самых популярных лечебных растений. Донецк: Мультипресс.

6. Гензель, В. (2016). Иллюстрированньй травник. 350 видов лекарственных растений. (Е. Живайкина, пер. с нем.). Харьков: «ПРАТ ХКФ Глобус».

7. 7.Чекман, И.С. \& Липкин, Г.Н. (1993). Растительные лекарственные средства. Киев: Колос. ИТЭМ.

8. 8.Липкан, Г.Н. (2014). Влияние препарата боярышника « Кардиплант» и «АТФ-ЛОНГ» на активность тканевого тромбапластина сердца старых крыс в условиях иммобилизационного стресса. Збірник наукових праць співробітників НМАПО ім. П.Л. Шупика. (4), 313-318.

9. 9.Бабушкина, А.В. (2010). Комбинированный препарат Кратал в терапии сердечнососудистых заболеваний. Український медичний часопис. (4), 60-66 


\section{SECTION IX. \\ SCIENCES PSYCHOLOGIQUES ET SOCIOLOGIQUES}

\section{DOI 10.36074/29.11.2019.v4.01 \\ MAIN CHARACTERISTICS OF REFLECTIONAL EDUCATION ENVIRONMENT}

Svetlana Yashnyk

D.Sc. in Pedagogy, Professor of the Department of Psychology The National University of Life and Environmental Sciences of Ukraine

UKRAINE

The professional competence of a future psychologist includes a reflexive competence. Scientists (O. Anisimov, A. Derkach, I. Zymnya, V. Metayeva, I. Semanov, etc.) emphases on metacompetential of reflective competence: with the help of reflective mechanism the timely correction and adequate development of all other competencies are ensured. Today, the most actual is a problem of reflective competence development not only at a level of learning and communication but also on a level of targets and achievements. (A. Derkach, V. Zhelanova, O. Rezvan, O. Chuiko). Such an approach to the professional development of future psychologists requires creation of a reflexive learning environment.

The term reflexive competence includes a system of well-developed reflexive skills and knowledge that ensure high productivity of intellectual actions of future psychologists by needed internal resources activation and organization of activities that are aimed at solving different collisions. Main reflexive skills include: ability to perform a "reflexive exit" and find reflexive position; ability to gain ways to "build meanings"; ability to correct and stimulate the new way to solve a problem; ability to separate, analyze, and compare own ways of thinking with the subject situation; self-awareness of subject's his own internal abilities and conditions; subject's ability to comprehend and evaluate own connections with other group members; ability to reflex and verbalize emotional conditions; ability to evaluate and use own psychological and professional resources; ability to perform a collection and fixate information about own qualities, characteristics, values, their efficiency based using a self-diagnostics methods; ability to find possible reasons of own professional and pedagogical issues; ability to determine ways to personal and professional improvement, etc. [4].

Reflexive competence development of future psychologists is possible only in a reflexive educational environment that is grounded on developing education ideas (L. Vygotskyy, V. Davydov, A. Dusavytskyy, D. Elkonin, V. Ryepkin, etc.). By reflexive educational environment, the system of personal development conditions is understood, which opens abilities to self- learning and self-correction of social, psychologic, and professional resources. Based on the analysis of a reflexive educational environment, we can outline its main functionals and characteristics. Following are suctions of educational environment: stimulating and developing (search of original and creative actions in educational activities); educational and 
diagnostic (creation of 'nearest zone of development' for assembling a 'innovation product' though constant renewable experience); expert and mind-flowing (intellectual space projecting to modificative ways of activity, aiming to solve the problem of discrete character in the education process); ethical and psychological (ensures prerequisites of constructive communication). Main characteristics of reflexive educational environment are: immersion (environmental conditions have to be close to future professional activity); presence (in reflective environment it determines the feeling of presence in professional environment while being in physical environment at the same time); interactivity (ability to participate for users in changing and developing the plot of the environment, in relations of personality and environment, which are subjects in relation to each other, that gives ability for environment to expand and enrich, creating a professional context in developing of future specialists) [2, 8].

Scientific generalizations of $\mathrm{V}$. Zhelanova allow to separate main features of reflexive educational environment: profession-oriented and reflexive-oriented angles; implementation of contexts majority of future professional activities; correspondence to personal needs of the student; availability of internal contradictions and obstacles connected to learning or professional activities; absence of hard regalements to work methodic and programs; priority of professional and developing educational methodic; usage of forms and methods of contextual education; alignment on developing all the types of reflections and levels of reflection as a good quality among students [3].

The critical moment in the understanding of reflexive education environment is it's learning context, which is displayed by the following characteristics:

- dominance - there is a potential to develop own qualities among future professionals, it's meaning to influence the person among other social influencers;

- a pedagogical intense - dynamic characteristic that proofs a level of the corresponding environment being fulfilled by the lecturer educating pedagogical innovations, untraditional forms, and methods to organize a learning process;

- emotional fulfill - sufficient ration in an environment of emotional and rational components;

- coherence - personal integration into the existing environment, conformity of different types of the environment (subject, educational and gaming, sociocultural, health-saving, computer-oriented, discoverable, etc.), where the student is in the reality of EIE;

- sociocultural mobility - serves as criteria of the social-oriented and creative potential of the environment, it's ability to perform progressive changes, quick implementation of innovations;

- coordinated - coherence of targets, plot, forms, methods of activities by all participants of the educational process, ability to perform an effective collaboration between them to create an efficient educational environment EIE;

- sustainability - proofs the stability of the environment against targeted and progressive influence on the development and progress of each student, realization of his creative potential in the education process, etc. [7].

Effectiveness of teaching future psychologists and forming a reflexive competence among them is mainly built on main principles of creating reflexive education environment: principle of uniqueness, which allows to consider each 
person and situation as unique; paradox principle, which outlines a human ability to overcome tension based on self and other existence; principle of open book, which represents conscious incompleteness of professional education; principle of superfluity, while future specialist can expand self and professional borders; principle of variations, which allows student and lecturer to build educational environment based on own needs and in connection to their direction of development $[1,5,6]$.

Summarizing all the above, we can admit that the primary condition to reflexive educational development is subjective of a pedagog and a student. The reflexive competence of future psychologists is formed during the process of solving professional issues. This process can be considered in a dimension of subjectsubject cooperation in the education process. Main prerequisites for developing and creation of reflexive education environment are: subject-subject cooperation, which is grounded on teamwork and confidence, confession to individualism, self-being, self-value of each person and foresees usage of corresponding principles: compassion, own and other's experience analysis, aimed creation of rich-emotional situations, etc., which ensures non-destructive tools of self development, polylogic in self-awareness, which ensures conscious self actualization and acting self realization of each individual, taking into consideration not only a zone of it's own closest development, but also development of other partners of reflexive process; development of success situations, which is about aimed and organized connection of prerequisites which lay basis to achieving results of being aware of own abilities, belief in own powers and experiencing satisfaction about results getting are in line with anticipated expectations or even fairly surpasses them.

\section{References:}

1. Носко, Л. А (2016). Емпіричне дослідження рефлексивності студентів-психологів. Актуальні проблеми психології, 7(42), 156-164.

2. Желанова, В. В. (2014). Динаміка середовища утворення в технології контекстного навчання майбутнього вчителя початкових класів. Педагогічний процес і практика: зб. наук. праць, (4), 27-32.

3. Смолюк, С. В. (2017). Організаційно-педагогічні умови становлення розвивального освітнього середовища в системі початкової освіти України (кінець XX - початок XXI ст.). (дис. ... канд. пед. наук). Луцьк.

4. Желанова, В. В. (ред.). (2012). Рефрлексивно-контекстне освітнє середовище як чинник професійної підготовки майбутнього вчителя початкових класів у ВНЗ. Педагогічний дискурс, (11), 88-93.

5. Чуйко, О. В. (ред.). (2013). Особистісне становлення суб'єктів профресійної діяльності у сочіономічних профресіях. Київ: АДЕФ-Украина.

6. Деркач, А. А. (ред.). (2004). Акмеологические основы развития профрессионала. Москва: Изд-во Московского психолого-социального института; Воронеж: «МОДЭК».

7. Перегончук, Н. В. (2016). Формування професійної компетентності майбутніх психологів у сучасному освітньому просторі. Наука і освіта, (11), 49-54.

8. Резван, О. (2015). Рефлексивне освітнє середовище як чинник розвитку особистості майбутнього фахівця. Педагогіка та психологія. (50), 290-299. 


\title{
PSYCHOLOGICAL ASPECTS OF THE STRUGGLE FOR TRUTH
}

\author{
Viacheslav Rubskyi \\ Cand. of Sciences in Theology, Senior Lecturer, Department of Practical Psychology \\ Odessa National Maritime University
}

UKRAINE

Recent years have not reduced the flow of publications about the nature of the search for truth, its structure, etc. Joshua Rasmussen investigates this in the field of philosophical theology [1], L.V. Beskrovnaya - in the field of art [2], S.V. Fedorov - in the philosophical key [3], Abelard Podgorski methodologically brings him closer to addictology [4].

The validity and indisputability of a thesis in one paradigm and its refutation in another paradigm cannot determine its truth or falsity, because «the inability to deny proves powerlessness but not" truth "» [5]. However, an important factor in confronting worldviews is the human psyche's request for confrontation itself, the will to power, the passion for the dispute as an epic battle. If we combine truth with passion, passion and passion, what will happen to it if we separate it? Will we find throughout this epic of feelings the very truth around which it all revolved?

When a person who has "found the truth" of theism, atheism, agnosticism, deism, etc., is directed to prove it. This means that she did not bring her comfort. Then she creates a sphere where she would have to defend and defend her. In this case it is impossible to say: does the adept defend the truth in the discussion or the very element of the discussion?

At the level of mental needs, we can capture the appeal of standing for the truth (the truth of the dispute) and the satisfaction of the truth beyond the confrontation (the truth for ourselves). With careful introspective analysis, we can find that these are different things, although in self-consciousness and for external audiences they are represented as one and the same. Often, truth-making does not make a person more balanced, joyful, but rather more restless. Hence the unfounded suspicions of psychologists that any kind of mission and the active promotion of their vision of the world have underpinned their uncertainty in it, a hidden attempt to consolidate positions for themselves, not for the addressees. Thus, even if he proclaims the truth, it is impossible to make a judgment as to whether he is telling the truth, since the nature of the discussion has its reasons sufficient to lead or escalate the confrontation.

In order to be able to capture the truth, it is necessary to remove it from opposition, because confrontation as a state of mind can be attractive to her. Truth is possible only at a distance from talking about it. Debates and conversations about truth are psychologically pleasing in themselves, no matter how far apart the participants are.

\section{References:}

1. Rasmussen, J. (2019). The Greatest Possible Being, by Jeff Speaks. Mind, fzz064. Doi: https://doi.org/10.1093/mind/fzz064

2. Beskrovnaya, L.V. (2017). Truth in art: hermeneutic in art. Philosophy and culture, 1, 98-105. Doi: 10.7256/1999-2793.2017.1.18369 
3. Fedorov, S.V. (2016) The main approaches to the problem of truth in the history of philosophy and Russian religious philosophy. Philosophy and Culture, 8, 1184-1191. Doi: 10.7256/19992793.2016.8.19870

4. Podgorski, A. (2019). Normative Uncertainty and the Dependence Problem. Mind, fzz048. Doi: https://doi.org/10.1093/mind/fzz048

5. Nietzsche, F. (2017). The Will to Power. Penguin Classics.

DOI 10.36074/29.11.2019.v4.02

\title{
АДАПТАЦІЯ ШКАЛИ ФРЕНСІСА «АФЕКТИВНЕ СТАВЛЕННЯ ДО ХРИСТИЯНСТВА» (FRANCIS SCALE OF ATTITUDE TO CHRISTIANITY») УКPAÏHСЬКОЮ МОВОЮ
}

\author{
Коваленко Юлія Василівна \\ здобувач наукового ступеня кандидата психологічних наук, \\ Інститут психології імені Г.С. Костюка НАПН \\ УКРАЇНА \\ викладач кафедри ALSUN \\ "Misr International University» \\ АРАБСЬКА РЕСПУБЛІКА ЄГИПЕТ \\ Науковий керівник: Тиха Еліна Вікторівна \\ канд. псих. наук \\ Інститут психології імені Г.С. Костюка НАПН
}

УКРAЇHA

Аналіз досліджень релігійності показує, що релігійність є складним та багатогранним явищем, яке $\epsilon$ недостатньо вивченим у зв'язку з тим, що дослідники вбачають у релігійності різні аспекти, ґрунтуючись на різноманітних теоріях. Крім того, існування чисельних методик виміру релігійності ускладнює інтегрування отриманих результатів у більш-менш цілісну картину.

Л. Френсіс провів серію досліджень у співпраці з міжнародною когортою науковців з метою більш інтегрованого підходу до емпіричного вивчення аспектів релігійності та подолання обмежень, викликаних розрізненістю уявлень, концептуалізації понять та теорій релігійності. Означені дослідження проводилися у крос-культурному контексті, охоплюючи основні релігії світу, включно з християнством, ісламом та юдаїзмом (Francis, 1989; Francis, Katz, Yablon, \& Robbins, 2008; Francis, Sahin, \& Al-Failakawi, 2008).

Методики виміру релігійності, запропоновані Френсісом, ґрунтуються на афективному аспекті релігійності, на відміну від її когнітивного та поведінкового компонентів, що стосуються духовної практики. Цей підхід знаходить відгук у справедливому зауваженні Корнієнко (2013) про те, що дотримання ритуальних та обрядових норм певної релігійної віри не $\epsilon$ тотожним до сильного емоційного переживання, яке і $€$ основою духовності людини. Підхід до вивчення релігійності як дослідження саме ставлення до релігії видається доречним, зважаючи на кілька причин. По-перше, у соціальній психології «ставлення» на концептуальному рівні розуміється як 
більш глибока, відносно стійка та тривала схильність/тенденція, на відміну від більш нестабільної та поверхневої поведінки чи думки. Афективний компонент $€$ найменш чутливим до впливів особистісних та контекстуальних фракторів. Крім того, інструментальні методики виміру афективного ставлення демонструють відносну стабільність у широкому віковому діапазоні вибірки. Також, очевидно, фоокус на афрективному ставленні до релігії дозволяє подолати конфесійні відмінності між, наприклад, коптами, греко-католиками та ортодоксами східного обряду, що входили до вибірки цього крос-культурного дослідження, оскільки конфесійна приналежність не впливає на визначення людиною афективних переживань щодо позитивного або негативного впливу віри та релігійних практик на їх життя. Таким чином, оцінка саме ставлення до релігії може дозволити долучитися до розуміння місця релігії у житті людини (Francis, 1989).

Адаптація української версії шкали Френсіса «Афективне ставлення до християнства» проводилася на 109 студентах двох вищих навчальних закладів міст Києва та Львову. Вибірка досліджуваних мала наступні демографічні характеристики: 46 чоловіків, 63 жінок; середній вік учасників емпіричного дослідження склав 24,5 роки. Адаптація української версії шкали Френсіса «Афрективне ставлення до християнства» в Україні проводилась 3 жовтня 2017 по січень 2018.

На першому етапі процесу адаптації була проведена культурна адаптація опитувальника, відповідно до вимог Міжнародної комісії з тестування (ITC) щодо правил перекладу та адаптації тестів (Test Translation and Adaptation Guidelines), які визначають процедуру культурної адаптації тестових методик з психології (Hambleton, 2001). По-перше, був виконаний переклад шкали Френсіса «Афективне ставлення до християнства» (Francis Scale of Attitude to Christianity) українською мовою; після чого зроблений зворотний переклад 3 української на англійську мову. Наступним кроком був переклад останньої англомовної версії знову на українську мову. На завершення, обом версіям двом англомовним та двом україномовним, - була дана порівняльна експертна оцінка незалежним висококваліфікованим психологом зі знанням англійської мови. На підставі підтверджених відповідностей між оригінальною та україномовною версіями шкали Френсіса «Афективне ставлення до християнства» була запропонована адекватна оригіналу українська версія опитувальника. В результаті, методика складається з 24 тверджень, на які треба відповідати за шкалою Лікерта від 1 = «саме так/беззаперечно погоджуюсь», до $5=$ «ні, це зовсім не так/зовсім не погоджуюсь». Єдиною відмінністю від англомовної версії була нумерація пунктів від 1 до 24 .

На другому етапі проводилася перевірка надійності української шкали Френсіса «Афеетивне ставлення до християнства». Для перевірки внутрішньої погодженості перемінних був застосований коефіцієнт а-Кронбаха. Значення коефіцієнта $\alpha$-Кронбаха для шкали українською мовою 0,79 свідчить про досить високу достовірність результатів, отриманих за допомогою означеної методики українською мовою, а отже дозволяє припустити надійність цієї методики. У Таблиці наведені статистичні результати перевірки методики на ступінь внутрішньої погодженості змінних.

Також були проаналізовані коливання коефіцієнту а-Кронбаха для видалених пунктів. Результати коливання коефіцієнту а-Кронбаха для видалених пунктів демонструють, що всі значення були меншими за загальне значення коефіцієнту а-Кронбаха $(0,790)$, що свідчить про те, що всі позиції 
опитувальника українською мовою $є$ значимими для загальної надійності методики. Крім того, значення загальної кореляції корельованих позицій були додатними та вищими за 0,2, що також є показником внутрішньої погодженості та надійності запропонованої української версії шкали Френсіса «Афективне ставлення до християнства».

На наступному етапі перевірялась конструктна валідність української версії опитувальника «Афективне ставлення до християнства Френсіса». Для цього була проаналізована наявність значущих рангових кореляцій за коефіцієнтом r-Спірмена між змінною «Афективне ставлення до християнства», вирахуваною за методикою «Афективне ставлення до християнства Френсіса», та показниками шкали «Релігійний копінг» опитувальника СОРЕ (Carver, Scheier, \& Weintraub, 1989). Такий аналіз наявності лінійних кореляцій було проведено (1) із застосуванням оригінальних версій опитувальника СОРЕ (Carver, Scheier, \& Weintraub, 1989) та методики Афективного ставлення до християнства Френсіса (Francis scale Attitude to Christianity) (Francis, 1989) на вибірці англомовних єгипетських християн-коптів (N 68), а також (2) із застосуванням адаптованої української версії опитувальника СОРЕ та української версії методики «Афективного ставлення до християнства Френсіса» (N 109). Крім того, змінна «Афективне ставлення до християнства» була перевірена на наявність рангових кореляції зі змінною «Моя релігія», визначеною за методикою «Аспекти ідентичності AIQ-IV» в адаптації О. Г. Угрин (Угрин, 2002) для української вибірки (N 109) та "Aspects of Identity AIQIV” (Cheek \& Briggs, 1982) для єгипетської вибірки (N 68) (табл. 1 та 2).

Таблиця 1

Рангові кореляції між показником афективного компоненту релігійності та шкалою «Релігійний копінг» і змінною «Моя релігія» для єгипетської вибірки

\begin{tabular}{|l|l|c|c|c|}
\hline & & $\begin{array}{c}\text { Змінна } \\
\text { «афективний } \\
\text { компонент } \\
\text { релігійності» }\end{array}$ & $\begin{array}{c}\text { Значимість 2- } \\
\text { стороння }\end{array}$ & $\begin{array}{c}\text { Кількість } \\
\text { випробовуваних } \\
\text { (N) }\end{array}$ \\
\hline$r$-Спірмена & $\begin{array}{l}\text { «Шкала Релігійний } \\
\text { копінг» }\end{array}$ & $-0,420^{*}$ & 0,015 & 69 \\
\hline$r$-Спірмена & Змінна «Моя релігія» & $0,606^{* *}$ & 0,000 & 69 \\
\hline
\end{tabular}

**Корелячія $\epsilon$ значимою при $p \leq 0,01$ (2-стороння значимість)

* Кореляція $\epsilon$ значимою при $p \leq 0,05$ (2-стороння значимість) [авторська розробка]

Таблиця 2

Рангові кореляції між показником афективного компоненту релігійності та шкалою «Релігійний копінг» і змінною «Моя релігія» для української вибірки

\begin{tabular}{|l|l|c|c|c|}
\hline & & $\begin{array}{c}\text { Змінна } \\
\text { «афективний } \\
\text { компонент } \\
\text { релігійності» }\end{array}$ & $\begin{array}{c}\text { 3начимість 2- } \\
\text { стороння }\end{array}$ & $\begin{array}{c}\text { Кількість } \\
\text { випробовуваних } \\
\text { (N) }\end{array}$ \\
\hline r-Спірмена & $\begin{array}{l}\text { Шкала } \\
\text { копінг» }\end{array}$ & $-0,531^{* *}$ & 0,000 & 109 \\
\hline r-Спірмена & Змінна «Моя релігія» & $0,363^{*}$ & 0,017 & 109 \\
\hline
\end{tabular}

**Кореляція $\epsilon$ значимою при $p \leq 0,01$ (2-стороння значимість)

* Кореляція є значимою при $p \leq 0,05$ (2-стороння значимість) [авторська розробка] 
Отже, англомовна та україномовна методики демонструють подібні помірні від'ємні зв'язки зі шкалою «Релігійний копінг», зі значеннями рангової кореляції Спірмена rho $=-0,420, p \leq 0,01$ для англомовної вибірки та rho $=-0,531, p \leq 0,01$ для української вибірки.

В цілому, можливо говорити про те, що хоча змінна «Афективне ставлення до християнства» та релігійний копінг досить тісно пов'язані, вони не $є$ тотожними конструктами. Цей висновок перекликається 3 результатами дослідження Ross, Handal, Clark та Vander Wal (2009) про те, що випробувані 3 високим ступенем індивідуальної релігійності та одночасно високими показниками самоспрямованості поведінки демонструють більш активну поведінку подолання, беруть відповідальність за вирішення проблеми на себе, не звертаючись до Бога. Цей результат також погоджується із висновком Тобалова (2004), який на підставі отриманих даних дослідження впливу індивідуальної релігійності на успішність подолання кризових ситуацій, стверджує, що більш релігійні віряни звертаються до більш ефективних активних, - стратегій подолання, на відміну від атеїстів, які застосовують більш емоційне реагування та уникання. У світлі нашого дослідження можливо припустити, що шкала «Релігійний копінг», яка передбачає більш активне залучення у релігійні практики, все ж таки є менш ефективною, на відміну від покладання відповідальності на себе, що сприяє більш успішному стресоподоланню (Тобалов, 2004). Що ж стосується виявлених зв'язків між змінною «Афективне ставлення до християнства» та «Моя релігія», попри те, що у єгипетській вибірці такі зв'язки були більш тісними, обидві версії шкали показали додатний середній зв'язок рангової кореляції Спірмена: $r \mathrm{ho}=0,606$, $p \leq 0,01$ для єгипетської вибірки та rho $=0,363, p \leq 0,05$ для української вибірки.

Висновки. Отже, можливо стверджувати, що показник «Афективного ставлення до християнства», обчислений за шкалою Френсіса «Афективне ставлення до християнства» виявив подібні від'ємні та додатні кореляції на різних вибірках випробуваних, що свідчить про конструктну валідність української версії шкали Френсіса «Афективне ставлення до християнства».

Таким чином, завдяки високій надійності цієї методики, внутрішній погодженості та конструктній валідності, українська версія шкали Френсіса «Афективне ставлення до християнства» може бути застосована для виміру афективного компонента релігійності української молоді.

\section{Список використаних джерел:}

1. Корнієнко, О. (2013). Мультикультуралізм як модель сучасного поліетнічного суспільства. Світогляд - Філософрія - Релігія, (4), 150-159. Вилучено 3 http://nbuv.gov.ua/UJRN/sfr_2013_4_18.

2. Тобалов, Ю. П. (2004). Совладание с трудными жизненными ситуациями у верующих. Автореф. дис. на соиск. учен. степ. канд. психол. наук: (19.00.05). Москва, 34. Вилучено 3 http://nauka-pedagogika.com/psihologiya-19-00-05/dissertaciya-sovladenie-s-trudnymizhiznennymi-situatsiyami-u-veruyuschih.

3. Угрин, О.Г. (2013). Адаптація англомовного опитувальника «аспекти ідентичності» (AIQ - IV) для дослідження української студентської молоді. Психолого-педагогічні умови розвитку освітнього простору держави: тези доповідей та повідомлень учасників 
Міжнародної науково-практичної конференції 22 листопада 2013 р. Львів: Львівський державний університет внутрішніх справ, 716.

4. Carver, C. S., Scheier, M. F., \& Weintraub, J. K. (1989). Assessing coping strategies: a theoretically based approach. Journal of personality and social psychology, 56(2), 267. Retrieved from https://citeseerx.ist.psu.edu/viewdoc/download?doi=10.1.1.1022.750\&rep=rep1\&type=pdf.

5. Cheek, J. M., \& Briggs, S. R. (1982). Self-consciousness and aspects of identity. Journal of research in personality, 16(4), 401-408. Retrieved from psycnet.apa.org.

6. Francis, L. J. (1989). Measuring attitude towards Christianity during childhood and adolescence. Personality and Individual Differences, 10(6), 695-698. Retrieved from psycnet.apa.org.

7. Francis, L. J., Katz, Y. J., Yablon, Y., \& Robbins, M. (2004). Religiosity, personality, and happiness: A study among Israeli male undergraduates. Journal of Happiness Studies, 5(4), 315333.

Retrieved

from https://link.springer.com/content/pdf/10.1023/B:JOHS.0000048460.35705.e8.pdf.

8. Francis, L. J., Sahin, A., \& Al-Failakawi, F. (2008). Psychometric properties of two Islamic measures among young adults in Kuwait: the Sahin-Francis Scale of Attitude toward Islam and the Sahin Index of Islamic Moral Values. Journal of Muslim Mental Health, 3(1), 9-24. Retrieved from https://www.researchgate.net/.

9. Hambleton, R. K. (2001). The next generation of the ITC Test Translation and Adaptation Guidelines. European journal of psychological assessment, 17(3), 164. Retrieved from psycnet.apa.org.

10. Ross K, Handal, P.J., Clark E.M., \& Vander, Wal JS. (2009). The relationship between religion and religious coping: religious coping as a moderator between religion and adjustment. $J$ Relig Health, 48(4), 454-67. doi: 10.1007/s10943-008-9199-5.

DOI 10.36074/29.11.2019.v4.03

\section{АНАЛІЗ СОЦІАЛЬНО-ПСИХОЛОГІЧНИХ ПРИЧИН АГРЕСІЇ В ПЕДАГОГІЧНОМУ СЕРЕДОВИЩІ}

Косило Христина Миронівна кандидат педагогічних наук, доцент кафедри міжнародної економіки, маркетингу і менеджменту Івано-Франківський навчально-науковий інститут менеджменту Тернопільського національного економічного університету УKPAÏHA

Освіта відіграє значну роль в формуванні гуманістичних цінностей та психологічного стану суспільства. Проте на фоні кризових явищ у суспільстві актуальною залишається проблема існування агресивності у педагогічному середовищі, що є особливо небезпечним, адже агресія чинить деструктивний вплив на підростаюче покоління. Тому важливим $€$ аналіз чинників, що формують агресивність педагогічного середовища, та розробка ефективних соціально-психологічних механізмів її зниження. Дослідження даних аспектів в 
Problèmes et perspectives d'introduction de la recherche scientifique innovante • Volume 4

суспільстві ґрунтовно здійснювали свого часу Е. Фромм, К. Лоренц, Дж. Доллард, 3. Фрейд та інші.

Сучасні дослідження проблеми агресивності переважно зосереджуються на чинниках, механізмах виникнення та запобігання формуванню дитячої агресивності, сором'язливо уникаючи питання агресії дорослих - тих, хто виховує та навчає дітей. Проте принципи надання практичної психологічної допомоги у подоланні агресивності ґрунтуються на твердженні про те, що насилля й агресія - то напучувана поведінка, яку дитина засвоює від дорослого як зразок для наслідування, а тому слід, на нашу думку, проаналізувати чинники агресивності дорослих.

Метою статті $є$ системний аналіз факторів фрормування агресивності у педагогів та пошук шляхів зниження проявів неконструктивної агресії засобами практичної психології. Агресія визначається як «...мотивована деструктивна поведінка, що суперечить нормам співіснування людей у суспільстві, завдає шкоди об'єктам нападу, людям, викликає в них психологічний дискомфорт (негативні переживання, стан напруги, страху, пригнічення і т.д.). Агресивні дії постають як: 1. Засіб досягнення значущої мети; 2. Спосіб психологічної розрядки; 3. Спосіб задоволення потреби в самореалізації та самоствердженні.

Виділяють різні види агресії: фрізичну, вербальну, пряму, опосередковану, інструментальну, ворожу, ауто агресію, альтруїстичну» [3].

Щоб зрозуміти природу агресивності в педагогічному середовищі, потрібно вивчити його специфріку, вдавшись до системного аналізу. Під педагогічним середовищем ми розуміємо групу педагогічних працівників, залучених у професійну діяльність, з усією сукупністю їх стосунків, взаємовпливів та взаємозалежностей. Педагогічне середовище можна розглядати як цілісний соцієтальний суб'єкт. Педагогічний колектив навчального закладу формує педагогічне середовище з притаманним йому духом. Окремі середовища можуть відрізнятися за характером, але на мікросоціальному рівні можна говорити про типове педагогічне середовище, яке формується під впливом чинників, спільних для суспільства, етносу, держави, регіону, професійної спільноти.

На сьогодні основу типового педагогічного середовища складають особи 3 вищою чи незакінченою вищою педагогічною освітою (95 \% мають закінчену вищу освіту). Близько 70 \% опитаних (в опитування брало участь 40 осіб з різних навчальних закладів) серед мотивів, що спонукали їх обрати професію педагога, на перше місце поставили інтерес до свого предмету і його знання. $45 \%$ опитаних вважають свою роботу тимчасовою, «до кращих часів», 85\% відчувають страх і небажання змінити роботу. 20\% опитаних досягли пенсійного чи передпенсійного віку, проте збираються працювати і надалі, 10\% вважають, що пенсіонер не може бути добрим учителем, $85,5 \%$ охоче відмовилися б від виконання обов'язків класного керівника, 30\% відповіли, що не погодяться бути класним керівником ні за яких обставин. $88 \%$ опитаних вважають, що якість педагогічної праці та ставлення до роботи прямо залежить від рівня заробітної плати. У ході опитування 3\% відзначили, що проблеми агресивності в педагогічному середовищі не існує, проте охоче надавали спонтанні коментарі з приводу причин агресивності окремих колег, що лише підтверджує наявність проблеми. Всі опитані періодично відчувають дефріцит позитивних емоцій та власну нереалізованість у зв'язку з виконанням професійних обов'язків, лише 5\% з них не відчувають хронічної втоми. 95,5\% 
визнає дефіцит уваги до себе та схвалення з боку колег і керівництва. $40 \%$ спокійно ставляться до відвідування своїх уроків колегами і адміністрацією, тоді як $62,5 \%$ вважають відвідування їхніх уроків стресом. $68 \%$ переживають через конфлікти з учнями, колегами, адміністрацією та особливо з батьками. Отже, сучасний педагог умотивований на викладання предмета, уникаючи відповідальності за виховну складову професійної діяльності, має незадоволену потребу схвалені та повазі (мовою транзакційного аналізу, недоотримує «позитивних погладжувань»), відчуває незадоволення оплатою праці, хронічну втому, стрес через професійне спілкування.

Освіта $€$ ієрархічною соціальною системою, де існує безліч правил дотримання яких $€$ обов'язковим. Тому в педагогічному середовищі розповсюджена конформістська агресія. Вона зумовлюється тим, що від педагога вимагають діяти саме так, і він вважає своїм обов'язком виконувати розпорядження. В усіх ієрархічних соціальних системах слухняність $€$ однією 3 основних рис характеру, яка схвалюється. Агресія знаходить вияв категоричних висловлюваннях та маніпулюванні оточуючими задля досягнення значущої для ролі вчителя мети (викладати предмет, навести порядок у класі, виконати програму, підвищити успішність, примусити учня носити форму і т.п.). Ще один аспект цього типу агресії - гендерний. Адже у школах працює більшість жінок, тоді як вчительство як особистісний акт вимагає чоловічих рис (активність, творчість,енергійність, воля, організаторські та комунікативні здібності, амбіційність). Тому зокрема і цікава тема для дослідження та практичного розв'язання - формування та трансформація статево рольової поведінки в освітньому середовищі.

Наступний вид агресії - захисна - також властивий педагогам. Людина захищається, коли загрожують її життєвим інтересам. Та сфрера вітальних інтересів людини є ширшою, ніж у тварин. Людині для виживання необхідні ще й психічні умови. І одна з них - збереження власної «системи координат», ціннісної орієнтації. Коли людина виявляє ідеї, які ставлять під сумнів ії життєві цінності, то сприймає це як загрозу. В хід ідуть психологічні захисти (раціоналізація, крик, звинувачення інших тощо), щоб подолати власний страх як реакцію на вітальну загрозу. Адже один з дієвих способів витіснення страху - напад. Цей вид агресії розповсюджений у професійному спілкуванні 3 учнями, колегами, батьками (суб'єктами освітнього процесу, залежними від педагога).

Під час аналізу стосунків педагогів 3 керівництвом та в процесі індивідуальної рефлексії можна зустріти іще один вид - ауто агресію; вона виявляється у почутті провини, яке виникає в учителя в ході оцінки його професійної діяльності. Адже корпоративна педагогічна етика вимагає від педагога постійного самовдосконалення та професійного зростання. Разом 3 тим,учитель, як правило, має дефіцит ситуації успіху, а якість його праці примушує учителя постійно тримати себе в певних моральних рамках. До ауто агресії здебільшого схильні особистості з розвинутим «родительським Я» (за Е. Берном), які не дають конструктивного виходу власному дитячому потенціалу. Можна сказати, що для педагога характерним є своєрідний «комплекс відмінника» - перфекціонізм. Також до ауто агресії схильні інфантильні особистості зі своєрідними тенденціями бути в ролі жертви, що мають низьку самооцінку та звинувачують себе в обмежених можливостях змінити професію, місце роботи, схильні до «трудоголізму», не вміють 
відмовлятися від надмірних обов'язків, мають песимістичний погляд на життя. Така поведінка нагадує поведінку заляканої істоти в безвихідній ситуації.

Серед деструктивних фоорм агресивної поведінки поширеною $є$ вербальна агресія у вигляді пліток, чуток, особистісних ярликів. Проявляється агресія як психологічне насилля (тиск, маніпулювання, дорікання, погрози, приниження гідності, демонстрація повчання, нетерпимість до відхилень від ідеальної моделі поведінки, обмеження свободи висловлювання думок, що суперечать точці зору вчителя, песимізм, нетерпимість до точки зору інших).

В педагогічному середовищі має місце і конструктивний вияв агресії: через наявність здорового духу змагання в колективі, вияв артистичних якостей, емоційну виразність педагогів та особливо через уміння вербалізації почуттів. Уміння конструктивного вияву агресії властиве для тих педагогів, які виявляють високий рівень діалогічності, авторитет серед учнів, колег та батьків. Вони можуть бути щирими, мають почуття гумору, розуміються на почуттях та висловлюють їх, вміють як похвалити, так і доброзичливо висловити зауваження, визнають свої помилки та вибачаються. Названі якості практичним психологам можна формувати у педагогів засобами психологічного консультування та групової роботи.

Можна зробити висновок, що подолання агресивності у педагогічному середовищі можливе за умови надання психологічної допомоги з метою підвищення діалогічності педагогів, навчання їх конструктивних форм реагування на негативні емоції, підвищення безконфрліктного спілкування. Зниження агресії не можна досягти прямими заборонами, залякуванням відповідністю чи постійним контролем, оскільки ці фрактори «заганяють» агресію вглиб особистості, внаслідок чого її прояви набувають витончених, але не менш деструктивних фрорм, що руйнують психологічне здоров'я як учителя, так і дітей.

Щодо перспектив подальшої роботи - розвиток у практичних психологів навчальних закладів професійних навичок консультативної та розвивальної роботи зі зниження агресивності педагогів шляхом участі психологів у проблемних і тематичних курсах, семінарах, тренінгах, а також систематичне підвищення психологічної культури педагогів.

\section{Список використаних джерел:}

1. Аксьонова, В. І. (2013). Регулятивні можливості соціальної комунікації:соціальнофрілософрський аналіз (с. 398-403). Київ: УАН ТОВ «НВП» «ВІР».

2. Aandriukaitiene, R. (2016). Connections of social responsibility, ethics and sustainability principles in the context of enhancing the organization's reputation. Humanitarian Bulletin of Zaporizhzhya State Engineering Academy: [GS Sciencesetc.]. Zaporizhzhya: Publishing ZDIA.

3. Бернацька, Л. В. (2008). Необхідність вивчення проблеми ранньої профрілактики й корекції агресивної поведінки дошкільників засобами спеціального психотренінга (с. 26-33). Київ: Наук. видання.

4. Білогур, В. Є. (2011). Світоглядні орієнтації студентів: тенденції змін у трансформаційному суспільстві. Дніпропетровськ: Пороги.

5. Мороз, О. С. (2016). Соціальний діалог і вирішення трудових спорів в умовах ресрормування судової влади і євроінтеграції. Klaipeda: BaltijaPublishing. ISBN 978-99348585-1-2. 
6. Савченко, С. В. (2014). Взаємодія культури і освіти в умовах інформаційного суспільства та культурної глобалізації: соціально- фрілософський вимір (с. 117-126). Запоріжжя: Вид во ЗДІА.

7. Шилина, Н. Е. (2015). Проблема целостности личности в современном развивающемся пространстве. Економіка та управління в умовах побудови інфоормаційного суспільства: Матеріали IV Міжнародної науково-практичної конференції, 27-28 квітня 2015 р. Одеса: ОНАЗ ім. О. С. Попова.

\title{
АНАЛІЗ СУЧАСНИХ ПОГЛЯДІВ НА ЕМОЦІЙНУ СФЕРУ ОСОБИСТОСТІ
}

\author{
П'янківська Людмила Володимирівна \\ канд. психол. наук, асистент кафедри педагогіки, \\ психології, медичного та фрармацевтичного права \\ Національна медична академія післядипломної освіти ім. П. Л. Шупика \\ УКРӒ̈HA
}

Емоційна сфера особистості є досить складною і багатогранною й завжди привертала увагу вчених. Вона охоплює широкий спектр переживань і почуттів. Вплив емоцій на стан здоров'я особистості та життєдіяльність у соціумі відбувається шляхом оцінювання предметів і явищ оточуючого середовища, спонукання до діяльності у певному напрямі, вирішення проблемних ситуацій, організації власної діяльності.

У сучасній психології емоційна сфера особистості є предметом досліджень та дискусій багатьох учених. Саме сучасний стан досліджень емоційної сфери на теоретико-методологічному рівні вказує на: наявність дискусійних питань щодо самого понятійного апарату, відсутність єдиної класифікації емоцій й різнобічність поглядів на їх походження.

До проблеми емоційної сфери особистості зверталися такі вчені, як: А.Бандура, О. Бреусенко-Кузнєцов, А. Бодальов, Л. Божович, Ф. Василюк, В. Вілюнас, Б. Додонов, П. Екман, К. Ізард, Г. Костюк, О. Леонтьєв, С. Рубінштейн, Р. Плутчик, К. Саарні, П. Сімонов, Г. Спенсер, Л. Фестінгер та iн. В роботах науковців розкриті положення про емоції та особливості їх переживання, різноманітність підходів, зв'язок емоцій з іншими психічними станами, значущість комунікативної сфери при їх виникненні.

Так, О. Леонтьєв розглядає емоції як категорію, що $є$ результатом діяльності, механізмом руху. С. Рубінштейн тлумачить їх як суб'єктивну форму існування потреб [4]. Г. Костюк підкреслює, що особливості вияву емоційних переживань залежать від рівня розвитку особистості та ії віку. В. Вілюнас вважає емоції внутрішніми сигналами й виконавцями функцій організатора поведінки особистості.

Аналіз наукових досліджень емоційної сфери особистості вказує на різноманітність теорій емоцій, кожна із яких розкриває якийсь один проблемний аспект її виникнення або певного ії компонента. 
3 огляду на наявну їх різноманітність серед науковців проаналізуємо сучасні наукові думки щодо окресленого контексту. Л. Фестінгер у розробленій теорії когнітивного дисонансу вважає емоції основними спонуками поведінки людини, що спричиняють дисонанс чи консонанс. Запропонована А. Бандурою теорія суб'єктної ефективності ґрунтується на існуванні взаємозв'язків між уявленнями людини, її емоційною збудливістю і поведінковими виявами. Г. Спенсер розглядає біологічну основу емоцій особистості та фактично виключає психологічного складову.

Не менш відомою $є$ адаптаційна теорія Р. Плутчика, що визначав емоцію як певну соматичну реакцію, яка пов'язана 3 конкретним адаптивним біологічним процесом, що притаманний усім живим організмам. Він структурував емоції так, що дало змогу представити емоційні стани в неперервній моделі. Р. Плутчик вважав емоції адаптивними засобами й розмежовував їх на первинні та вторинні [6].

Найпоширенішим у практичному застосуванні та науці $є$ вчення про емоції та їх диференціацію К. Ізарда. Він виокремлює психодинамічний, когнітивний, дименсійний, соціально-когнітивний, когнітивно-фрізіологічний підходи. Вчений відносить емоції до теорії «Я», де пізнання окреслюється як причина та компонент емоцій. Також він виділяє й ґрунтовно описує десять базових емоцій, що виявляють себе шляхом виразної та специфічної конфрігурації м'язових рухів обличчя. Дослідник вказує на різноманітність ролей емоцій, особливо негативних [1].

Автор судинної теорії емоцій І. Уейнбаум визначає тісний взаємозв'язок між м'язами обличчя та кровообігом у мозку й припускає, що м'язи обличчя можуть виступати механізмом зміни кровообігу. Цю теорію у подальшому модифрікували С. Томпкінс та Р. Зайонц.

У цьому контексті варто звернути увагу на дослідження самого Р. Зайонца. Він виявив вплив температури мозку на знак пережитої емоції й цим модифрікував судинну теорію. Дослідник вказує, що зміна температури мозку викликається відтоком венозної крові від м'язів обличчя і тому холодне повітря завжди оцінюється особистістю як неприємне, а тепле - як приємне. Таким чином, кровообіг між м'язами обличчя має вплив на температуру мозку та змінює емоційні переживання [5].

Згідно нейрокультурної теорії емоцій П. Екмана експресивні прояви базових емоцій (страху, гніву, печалі, відрази, подиву, щастя) $\epsilon$ універсальними та майже залишаються без змін під впливом оточуючого середовища. Він вказує, що особистість на генетичному рівні використовує рухи м'язів обличчя при вияві емоцій, але разом з цим визначальним $є$ вплив загальноприйнятих суспільних норм соціального контролю [3].

На сьогодні існують цікаві й глибокі дослідження емоцій сучасного науковця Л. Барретт. Дослідниця пропонує нове бачення щодо природи виникнення та самого розуміння емоцій. Вона вперше виявила й описала явище сприйняття емоцій й назвала його емоційною гранулярністю [2].

Л. Барретт висунула власну теорію конструйованих емоцій, що базується на найсучаснішому нейрологічному розумінні роботи мозку. Вчена доводить, що природою емоцій є мінливість, а базові для нас емоції «гнів», «страх», «радість», «смуток» вона рекомендує відносити до категорій емоцій. 
Конструювання людиною власного емоційного досвіду дослідниця називає випадком емоцій, а набір рухів мімічних м'язів - мімічною конфігурацією.

Вона зазначає також, що емоції не зумовлені генетично, а уявлення про них залежать від соціального контексту. Л. Барретт об'єднує ряд елементів трьох напрямів у теорії конструйованих емоцій: «соціальне конструювання», що досліджує роль соціальних цінностей й інтересів у визначенні сприйняття світу; «психологічний» - перенесення центру уваги всередину, тобто наші сприйняття, думки й почуття самоконструюються із базових складових; «нейроконструювання» - досвід людини формує зв'язки мозку.

Вчена вважає, що емоції - це значення. Вона вказує, що вони створюються у мозку й пояснюють інтероцептивні зміни особистості та афективні відчуття відповідно до наявної ситуації. Л. Барретт вважає їх приписом до дії та соціальною реальністю.

Отже, сучасний стан досліджень емоційної сфери особистості засвідчує, що більшість теорій емоцій пояснюють певні механізми їх виникнення, але єдиної загальноприйнятої немає. Кожна із них має право на існування та розкриває власний погляд на емоційну сферу.

\section{Список використаних джерел:}

1. Изард, К. Э. (2011). Психология эмоций. Санкт-Петербург : Питер.

2. Барретт, Л.Ф. (2018). Як народжуються емоції. Харків : Клуб Сімейного дозвілля.

3. Экман, П. (2016). Психология эмоций. Санкт-Петербург : Питер.

4. Рубинштейн С. Л. (2002). Основы общей психологии. Санкт-Петербург : Питер.

5. Adelmann, P. K., Zajonc, R. B. (1989). Facial Efference and the Experience of Emotion. Annu. Rev. Psychol. (40 (1), 249-280.

6. Plutchik, R. (1980). Emotion: A Psychoevolutionary Synthesis. Harper \& Row.

\section{ДІАГНОСТИКА ДОМІНУВАННЯ НАВЧАЛЬНИХ АБО ІГРОВИХ МОТИВІВ ДО НАВЧАННЯ В ШКОЛІ}

Чекстере Оксана Юріївна кандидат психологічних наук, старший науковий співробітник Інститут психології імені Г.С.Костюка НАПН України

УКРАÏHA

Мотивація є складним, багаторівневим і до того ж постійно змінюваним психофрізичним процесом. Майбутній школяр для гармонійного психічного розвитку повинен мати сформовану зрілу навчально-пізнавальну мотивацію, стійке бажання вчитися. Діти, що поступають до школи мають різні рівні мотиваційної готовності до навчання, їх спонукають різні мотиви і бажання навчатися в школі. У деяких дітей зовсім не виникає бажання вчитися. Деякі діти хочуть йти до школи не тому, що вони готові навчатися, а тому, що для них це зовнішні яскраві шкільні атрибути, нові друзі, нова позиція в системі доступних їм суспільних відносин. Деякі діти реалізують мотиви, які 
безпосередньо пов'язані з навчальною діяльністю, відчувають потребу в інтелектуальній активності і в оволодінні новими уміннями, навичками і знаннями. Готова до школи дитина хоче вчитися, так як це дозволить їй зайняти певну позицію в суспільстві людей і до того ж у неї є пізнавальна потреба, яку вона не може задовольнити вдома або в дитячому садочку. Сплав цих двох потреб сприяе виникненню нового формування, названого Л.І. Божович «внутрішньою позицією школяра» [1]. «Внутрішня позиція школяра» може служити одним з важливих критеріїв готовності до шкільного навчання.

При перевірці готовності дітей до навчання в школі об'єктивна діагностика може бути ускладнена тим, що старші дошкільники досить добре засвоюють соціальні норми, орієнтуються на оцінки їх поведінки іншими і намагаються дати схвалювані з боку значущого дорослого відповіді. Тому нам в роботі знадобився діагностичний інструмент, що дозволяє за короткий проміжок часу виявити дітей, у яких не сформоване позитивне емоційне ставлення до навчання. Цим інструментом стали проектні методики. Вони не вимагають тривалого обстеження і в той же час виділяють достатні компоненти для висновку про готовність дитини до школи.

Для з'ясування мотиваційної готовності старших дошкільників до навчання нами було протестоване 124 дитини віком від 5,5 до 6 років (68 дівчат і 56 хлопчиків) - вихованців дошкільного освітнього закладу Дніпровського району міста Києва.

Саме обстеження проводилося в ході спільної ігрової діяльності з дітьми. На заняттях ми проводили гру «Панда Кунг-фу». Діти сиділи у колі на килимі, в центрі кола знаходився ведучий. Кожен з дітей по черзі побував в ролі «Панди». Діти вимовляють будь-які слова, що приходять їм на ум, на які "Панда" емоційно реагує - якщо слово їй подобається, вона кланяється, склавши долоні, якщо ні - приймає бойову стійку. Діти із задоволенням включалися в гру, а педагог промовляв слова, що мають відношення до шкільного навчання: школа, урок, математика, вчителька, перерва. Образ іншої істоти, в яку перетворюються діти, дозволяє їм позбутися суб'єктивного контролю відповідей.

Серед багатьох питань, що задають дитині, обов'язково три питання про школу. Саме відповіді на ці питання педагог заносить до протоколу. Якщо всі відповіді позитивні, значить у дошкільника сформоване позитивне емоційне ставлення до навчання; одна або дві позитивні відповіді - середній рівень мотивації; а якщо всі відповіді негативні, значить у дитини низький рівень мотиваційної готовності до навчання.

Результати дослідження приведені в Таблиці 1.

Таблиця 1

Розподіл дітей за рівнями мотиваційного ставлення до навчання в школі за методикою «Панда Кунг-фу», у відсотках

\begin{tabular}{|c|c|c|c|c|c|c|}
\hline Рівні мотивації & \multicolumn{2}{|c|}{ високий } & \multicolumn{2}{c|}{ середній } & \multicolumn{2}{c|}{ низький } \\
\hline$\%$ & \multicolumn{2}{|c|}{63} & \multicolumn{2}{c|}{30} & \multicolumn{2}{c|}{7} \\
\hline & дівчата & хлопці & дівчата & хлопці & дівчата & хлопці \\
\hline & 71 & 53 & 26 & 34 & 3 & 13 \\
\hline
\end{tabular}


Як видно з даних таблиці - високий рівень мотивації до навчання в школі отримали $63 \%$ дітей (53\% хлопчиків і $71 \%$ дівчат). Ці діти продемонстрували емоційно- благополучне відношення до школи й навчання, їх приваблює шкільне життя і у них немає страхів щодо нової навчальної діяльності.

Середній рівень посіли $30 \%$ вихованців (26\% дівчат і $34 \%$ хлопців). Ці діти мають кілька обмежене уявлення про діяльність школярів і вчителя. Частина дітей сприймає навчання як гру, орієнтуючись головним чином на зовнішні ознаки.

Низький рівень мотивації до навчання в школі - виявився в $7 \%$ дітей (3\% дівчат і 13\% хлопців). В цих дошкільників не сформована внутрішня позиція школяра, а провідним мотивом $є$ ігровий. Вони можуть боятися змін, школи, відмовлятися від навчальної діяльності.

Отримані дані можна перевірити в ході іншої гри «Море радості» (Маркушева М. Є.) [2]. Діти знаходяться на «піску», педагог виділяє лінію «море», а потім називає будь-які події, що мають для дитини певну значимість. Якщо вони подобаються дітям, діти «виходять плавати в морі», а якщо ні залишаються на «піску». Спочатку даємо дітям зрозуміти, що одна і тай же подія комусь може подобатися, а комусь - ні. «Святий Миколай подарував на свято ляльку» - дівчаткам ця подія приносить радість, а хлопчики дружно реагують: «ні, ні». Реакцію дітей на події типу: «треба йти до школи», «похвалила вчителька», «розв'язуємо приклади) - необхідно відзначати в протоколі. Отримані дані представлені в таблиці 2.

Таблиця 2

Розподіл дітей за рівнями мотиваційного ставлення до навчання в школі за методикою «Море радості», у відсотках

\begin{tabular}{|c|c|c|c|c|c|c|}
\hline Рівні мотивації & \multicolumn{2}{|c|}{ Високий } & \multicolumn{2}{c|}{ середній } & \multicolumn{2}{c|}{ низький } \\
\hline$\%$ & \multicolumn{2}{|c|}{66} & \multicolumn{2}{c|}{30} & \multicolumn{2}{c|}{4} \\
\hline & дівчата & хлопці & дівчата & хлопці & дівчата & хлопці \\
\hline & 71 & 60 & 24 & 37 & 5 & 3 \\
\hline
\end{tabular}

За даними методики $66 \%$ досліджуваних дітей отримали високий рівень мотиваційної готовності до школи, 30\% посіли середній рівень, $4 \%$ дітей 3 різних причин не хочуть йти до школи.

Перевага даних методик вивчення мотиваційної готовності до школи в тому, що діагностика не займає багато часу, а самі методики можуть бути включені в основний цикл занять по соціально-емоційному розвитку дітей.

Отже, в ході дослідження з'ясувалось, що переважна кількість досліджуваних дітей старшого дошкільного віку достатньо мотивована до навчання у школі. Показники мотиваційної готовності до навчання у дівчат більш високі ніж у хлопців, а хлопцям притаманні та найбільш значущі ігрові мотиви.

\section{Список використаних джерел:}

1. Божович, Л. И. (2008). Личность и ее формирование в детском возрасте. СПб.: Питер.

2. Маркушева, М. Е. (2011). Диагностика мотивационной готовности детей к школьному обучению с помощью проективных методик. Электронный журнал "РОНО", (9) . Вилучено $3 \mathrm{https}: / /$ sites.google.com/a/shko.la/ejrono_1/vypuski-zurnala/vypusk-9-mart-2011/innovaciipoiski-i-issledovania/. 


\title{
ОСОБЛИВОСТІ ПОВЕДІНКИ ВАЖКОВИХОВУВАНИХ ПІДЛІТКІВ ТА ШЛЯХИ ІІІ КОРЕКЦІї
}

\begin{abstract}
Яшник Світлана Валеріївна
Національний університет біоресурсів і природокористування України

Верхуша Юлія Сергіївна

Національний університет біоресурсів і природокористування України

УКРАÏHA
\end{abstract}

У статті розглядається поняття важковиховуваності, причини появи важковиховуваних дітей, типологічні групи важковиховуваних, суть, етапи, принципи перевиховання важковиховуваних дітей.

Дослідженню проблеми «важковиховуваних» і психологічні особливості підліткового віку досліджували М. Алемаскін, Л. Зюбіна, Н. Верцинська; шляхи та методи виправлення поведінки підлітків з психологічної точки зору запропонував А. Кочетов; вивченням важковиховуваності як передумови виникнення відхилень у поведінці займались А. Капська, Л. Мардахаєв, В. Сорочинська, Ю. Василькова; особливостям профрілактики важковиховуваності підлітків приділяли увагу Л. Колесова, Н. Максимова. У 70 ті роки XX століття проблему важковиховуваних дітей досліджував В. Сухомлинський. Він стверджував, що «важковиховувана» дитина - це знедолена, нещасна дитина, яка втратила здатність виховуватись; стала хворобливою сприятливою до найменших проявів несправедливості, байдужості [7].

Важковиховуваність - стан особистості, породжений несприйняттям запропонованих установок; вияв негативних якостей у поведінці; поведінка, яка виходить за межі соціальної норми внаслідок неправильного вибору шляхів самоствердження тощо [6]. Варто також розрізняти терміни «важковиховувані діти» і «педагогічно запущені діти». Усі важковиховувані, звичайно, є педагогічно запущеними. Але не всі педагогічно запущені діти важковиховувані: багато з них відносно легко піддаються перевихованню, на відміну від нелегкого коректування порушень поведінки важковиховуваних дітей і підлітків [1].

Важковиховувані діти - (соціально дезадаптовані або з ускладненою поведінкою) - це діти, в яких виникають проблеми із соціалізацією, зокрема важко формуються моральні норми, як наслідок - відхилення форм поведінки, зниження або втрата почуття відповідальності за свої вчинки. Нерідко цих дітей називають афективними, недисциплінованими, педагогічно занедбаними. Таким особам властиві:

- неправильно сформовані потреби: матеріальні переважають над моральними; більшість матеріальних потреб мають аморальний характер; для їх задоволення важковиховувані особи використовують засоби, які не завжди відповідають нормам моралі (вживання алкоголю, наркотиків, крадіжки), що призводять до деградації особистості; 
- прагнення до спілкування з подібними до себе, перебування поза зв'язками з постійними учнівськими колективами;

- нерозвинута потреба пізнання навколишнього світу; незадовільне навчання, ігнорування методів пізнавальної діяльності;

- непослідовність, суперечливість у поглядах і переконаннях;

- брак уявлень про норми поведінки, обмежені почуття відповідальності за свої вчинки;

- приховування своїх вчинків від батьків, учителів та однокласників [6].

-Причин появи важковиховуваних дітей $є$ досить багато, однак, серед основних ми можемо виділити: неблагополуччя в сім'ї:

- неповна сім'я, батьки, які ведуть аморальний спосіб життя; безвідповідальність батьків за виховання дітей, їх психолого-педагогічна неграмотність;

- низька педагогічна культура в благополучній сім'ї: батько й мати працюють, освічені, інтелектуально розвинені, є матеріальний достаток, що проявляється у створенні для дітей «парникових» умов, призводить до ослаблення внутрішніх сил особистості;

- недостатній виховний рівень роботи в загальноосвітніх закладах: проявляється у перевантаженості програм навчальним матеріалом, який учень не може засвоїти;

- особливості особистості дитини: неадекватність самооцінки та рівня домагань, невміння спілкуватися, відсутність сенсу та чіткої мети в житті, відсутність суб'єкта турбот, відсутність інтелектуальних та естетичних інтересів, реакція на пережиту важку ситуацію, емоційна недорозвиненість, проблеми сфери мотивації та потреб, відсутність дисциплінованості, безвідповідальна поведінка;

- негативні приклади поведінки дорослих та референтних груп, а також спілкування з правопорушниками та з людьми, які мають шкідливі звички;

- вплив засобів масової інформації [3].

Особливості психології важковиховуваного дозволяють йому швидко адаптуватися в групі подібних однолітків. Саме тому і не набули поширення так звані «класи педагогічної підтримки», оскільки диференціація у них носила швидше зовнішній характер, ніж внутрішній.

У першу профілактичну групу, входять «вразливі» діти, яким притаманні високий рівень тривожності та різні рівні дезадаптації, які виступають основними чинниками девіантної поведінки дітей цієї групи [4].

Встановлено, що спільним для дітей цієї групи є: надмірна особистісна тривожність; емоційна напруженість та швидка зміна настрою; ізольованість у групі однолітків; похмурість; постійне очікування негативних оцінок; емоційна вразливість, нервозність; апатія, в'ялість та безініціативність.

До другої профрілактичної групи - «конфліктних» - можна умовно включити важковиховуваних з низьким рівнем комунікативних здібностей, високим рівнем конфліктності. Ці ознаки можуть поєднуватися також 3 високою тривожністю, імпульсивністю, низьким рівнем мотивації досягнень.

Загальна характеристика другої профрілактичної групи: діти мають труднощі у встановленні контактів з однолітками, не прагнуть до спілкування; вважають за краще проводити час наодинці; не відстоюють свою думку; важко 
переживають образи; хворобливо реагують на критику; проявляють негативізм [4].

До третьої профрілактичної групи - «самовпевнених» - можна віднести дітей, для яких характерна неадекватна, переважно завищена самооцінка та висока схильність до ризику. Вони можуть зумовлювати девіантну поведінку, поєднуючись з високою імпульсивність та конфліктністю. Однак у таких дітей проявляються різні рівні адаптованості, достатньо розвинені комунікативні вміння та мотивація досягнень.

Для важковиховуваних цієї профілактичної групи характерна спрямованість на себе, порушення соціальних норм у поведінці та спрямованість різкого негативного характеру у поєднанні 3 порушенням правових норм. Таким чином, можна зробити висновок, що удосконаленню організації психолого-педагогічної профрілактичної роботи сприятиме врахування загальних, типологічних та індивідуальних особливостей неповнолітнього при вирішенні конкретних проблем [4].

Процес виховання передбачає подолання негативних рис особистості тобто перевиховання і виправлення. Перевиховання - виховний процес, спрямований на подолання негативних рис особистості, що сформувалися під впливом несприятливих умов виховання. Процес перевиховання спрямований на виправлення важковиховуваних педагогічно занедбаних неповнолітніх, правопорушників [3]. Виправлення - складний психічний процес перебудови особистості, що відбувається під впливом перевиховання і самостійної роботи особистості над усуненням відхилень у своїй свідомості та поведінці [5].

Причини появи важковиховуваних дітей пов'язані 3 недоліками та помилками сімейного, шкільного виховання, аморальними явищами середовища, згубним впливом низькопробної кіно продукції, літератури тощо.

Процес перевиховання охоплює такі етапи:

1. Підготовчий етап. Суть його полягає в детальному вивченні й аналізі позитивних і негативних якостей педагогічно занедбаного учня, умов, що спричинили їх виникнення, визначенні шляхів нейтралізації негативних i посиленні позитивних якостей особистості, конкретних завдань і змісту процесу перевиховання.

2. Початковий етап. На цьому етапі починається реалізація наміченої програми роботи з учнем, внаслідок якої він поступово долає помилкові погляди і переконання, негативні звички поведінки, у нього зміцнюються позитивні й формуються нові риси характеру.

3. Переломний етап. У цей період триває реалізація уже визнаної i прийнятої підлітком програми роботи. Тому він добровільно виконує свої обов'язки, виявляє самостійність і активність.

4. Завершальний етап. На цьому етапі створюють умови для залучення учня до активної участі в усіх видах системної діяльності, нагромаджується позитивний досвід поведінки, розширюється сфера самовиховання [2].

Перехід від одного до іншого етапу перевиховання у різних категорій вихованців $€$ неоднаковим, він залежить від рівня їх педагогічної занедбаності, ставлення до процесу перевиховання, ефективності навчально-виховної роботи в школі та ін. [5].

До специфічних принципів перевиховання належать: 
1. Поєднання переконання з примусом. Передбачає використання методів виховного впливу на вихованця залежно від рівня розвитку його свідомості, що вищий рівень свідомості, то більше задіюється методів переконання, і навпаки.

2. Гуманне ставлення до важковиховуваних учнів. Вони не зможуть осягнути сутність моралі гуманізму, якщо не відчують гуманного ставлення до себе дорослих і однолітків.

3. Об'єктивне ставлення до важковиховуваного учня у процесі його перевиховання. Передбачає виявлення не лише негативних, а й позитивних якостей, на які спираються у процесі перевиховання.

4. Ставлення до важковиховуваного учня, як і до всіх школярів. Йому не слід дорікати перед колективом, що він не такий, як усі, гірший за інших, бо це озлоблює і викликає бажання стати ще гіршим.

5. Педагогічний вплив на важковиховуваного учня в неефектному стані. Виключає вплив на нього відразу після скоєння негідного вчинку, оскільки в такому стані педагог не може бути об'єктивним, а учень - зрозуміти справедливість педагогічного впливу [2].

Перевиховання важковиховуваного учня здійснюють у загальному процесі навчально-виховної роботи школи із залученням до неї учнівського колективу, батьків, громадськості, 3 використанням загальнопедагогічних методів виховання, враховуючи при цьому специфічні особливості його особистості [1].

На основі аналізу різних дослідників розкрито сутність поняття важковиховуваністі як складне явище, обумовлене безліччю різних причин i факторів. Діяльність педагога з її подолання вимагає спеціальної роботи при обов'язковому комплексному підході до вирішення цього завдання, коли спеціальні засоби, прийоми, заходи органічно вплітаються в систему навчання і виховання в цілому. Процес виховання передбачає подолання негативних рис особистості, тобто перевиховання. Процес перевиховання охоплює чотири етапи: підготовчий етап, початковий, переломний та завершальний етапи. На всіх етапах слід дотримуватись наукових принципів, які визначають основні вимоги до змісту, форм і методів виховної роботи, а саме: принцип поєднання переконання з примусом, гуманне ставлення до важковиховуваних учнів, випереджувальне формування позитивних якостей, а не боротьба 3 недоліками та інші.

\section{Список використаних джерел:}

1. Капська, А. Й. (2000). Соціальна педагогіка (5-те вид. перероб. та доп.) (с. 2011-488). Київ: Центр учбової літератури.

2. Зверєва, І. Д. (ред.). (2012). Енциклопедія для фрахівців соціальної сфрери. Київ, Сімферополь: Універсум.

3. Блонський, П. П. (ред.). (2005). Недесципліновані школярі. Москва: Кондор.

4. Власова, О. І. (ред.). (2005). Педагогічна психологія. Київ: Либідь.

5. Вольнова, Л. М. (ред.). (2008). Методичні рекомендації щодо психолого-педагогічної роботи з важковиховуваними неповнолітніми. Київ: НПУ ім. М. П. Драгоманова.

6. Головінський, І. 3. (ред.). (2003). Педагогічна психологія. Київ: Аконіт.

7. Василькова, Ю. В. (ред.). (1999). Социальная педагогика. Москва. 


\title{
ПСИХІЧНА КУЛЬТУРА ЯК ДИНАМІЧНЕ УТВОРЕННЯ ПРИ ПРОФЕСІЙНОМУ СТАНОВЛЕННІ МАЙБУТНЬОГО ФАХІВЦЯ МОРСЬКОГО ТРАНСПОРТУ
}

\begin{abstract}
Сорока Олена Михайлівна
канд. психол. наук, доцент кафедри навігації і управління судном Дунайський інститут Національного університету «Одеська морська академія»

УКРАÏHA
\end{abstract}

Сучасна профресійна освіта фахівця морського транспорту спрямована на підготовку конкурентоспроможного фахівця, здатного до саморозвитку у професійній діяльності, особистості зі стійкою системою цінностей. Метою сучасної професійної освіти стає підготовка фрахівця як носія загальної і професійної культури. Зумовлена специфікою професійної діяльності, відповідними цінностями та традиціями морської професійної сфери, професійна культура залишається невід'ємною складовою загальної культури особистості фахівця. Тому формування професійної культури майбутнього фахівця має ґрунтуватися на загальнолюдських цінностях та досвіді минулих поколінь, враховувати тенденції розвитку певної професійної галузі та суспільства в цілому.

В межах професійної культури моряка визначають її органічну складову психічну культуру. Психічна культура - це різнопланове багаторівневе динамічне утворення в структурі особистості моряка, яке забезпечує максимально високий рівень розвитку усіх складових його психічного реагування. Структура психічної культури особистості моряка має такі складові: знання в галузі психології про закономірності та механізми функціонування психіки особистості; високий рівень розвитку усіх актуальних можливостей психіки моряка, його індивідуальних психічних явищ; уміння свідомого психічного самовпливу з метою забезпечення високого рівня емоційно-вольової та психоемоційної стійкості, що можуть бути сфрормованими на підставі звернення до методів свідомого психічного самовпливу та навички індивідуальної психічної гігієни.

Психічна культура курсанта вищого навчального морського закладу передбачає знання та уміння про наступне: актуальні можливості та закономірності своєї психіки; її резервний потенціал; рівень особистої емоційно-вольової стійкості та її значення в процесі виконання професійних завдань; сутність природних механізмів свідомої психічної саморегуляції; технологією користування методами свідомого психічного самовпливу; вимоги індивідуальної психогігієни тощо.

Після пробудження у курсанта інтересу та самоповаги до себе як майбутнього дипломованого моряка, до рівня розвитку своїх особистих здібностей, особистих психічних пізнавальних процесів, психологічних особливостей та моральних якостей, що повинні відповідати вимогам його 
професії, майбутній моряк має поширити знання в галузі психології, познайомитися 3 резервними можливостями особистої психіки, вміти формувати уміння свідомого психічного самовпливу з метою оптимізації особистого психофізіологічного стану. 3 цим підвищується рівень соціальної перцепції, емпатія, рефлексія, комунікативні здібності, професійна самопрезентативність. Надалі курсант набуває вміння застосовувати знання, уміння та навички свідомого психічного самовпливу в процесі виконання професійних завдань.

Курсанти та студенти повинні знати, що в структурі психіки особистості $€$ певні фази, а також два основних рівні - підсвідомий та свідомий. Вчені доводять, що психіка сучасної особи має резервні механізми. Цей факт є значущим для професійного психологічного самовдосконалення моряка. Треба знати, що кожній психічно здоровій особі притаманні види психічної саморегуляції - підсвідомий та свідомий. Специфіка роботи в морі, значне фізичне та психічне навантаження вимагає від курсанта та студента навчитися користуватися додатковими механізмами завдяки оволодіння уміннями свідомої психічної саморегуляції. Цей вид саморегуляції представляє собою систему цілеспрямованого психічного самовпливу 3 метою значного підвищення рівня психофрізичної спроможності моряка.

Існує дві основні групи методів психічного самовпливу:

а) методи емоційно-вольового самовпливу, серед яких визначають самонаказ, переконання, самопримушення тощо;

б) методи психічного самовпливу, що спираються на механізм самонавіювання, а тому не передбачають вольових зусиль чи фактору переконання.

Треба запам'ятати, що серед методів психічного свідомого самовпливу другої групи визначають аутотренінг, медитацію та аутогіпноз. Усі вони $\epsilon$ достатньо впливовими, але не усі $€$ небезпечними для психічного здоров'я особи. 3 метою дотримання принципу систематичності та послідовності $€$ доцільним спочатку звертатися до методу аутотренінгу. Він $€$ безпечним, дозволяє отримати бажаний результат поза перевантаження особистої психіки.

Аутотренінг вимагає від моряка дотримання двох основних умов: а) м'язового розкріпачення; б) промовляння про себе формул самонавіювання відповідного змісту. Ці формули мають форми самопідбадьорення, самонаказів, які застосовуються як елемент аутогенної корекції психіки людини у комплексі з іншими аутопсихологічними вправами, що стабілізують її при впливі екстремальних чинників: «Я керую собою», «Я завжди володію собою», «Я сміливий, рішучий у будь-якій обстановці», «У складній обстановці я спокійний», «Я завжди готовий до виконання завдань в складній обстановці», «Я цілком можу стримувати себе», «Я володію своїми емоціями», «Я завжди зібраний, організований, уважний», «Я наполегливий у досягненні мети» та ін. Ці форми самопідбадьорення та самонаказів виконуються, в основному, після виконання комплексу вправ аутогенного тренування, однак можуть бути застосовані і в будь-якій інший вільний час; повинні проговорюватись подумки, інколи вголос, забезпечуючи в загальному здатність фахівця морського транспорту до самокорекції, самоконтролю, саморегуляції тривоги та страху 
перед ймовірними фаховими екстремальними ситуаціями. Ці формули можна широко варіювати при практичному застосуванні, забезпечуючи через позитивне самоналаштування до дій загальне зміцнення емоційно-вольової сфери для підвищення психологічної готовності майбутніх морських фрахівців до професійної діяльності в екстремальних ситуаціях [3].

Таким чином, однією з основних задач, що ставить перед собою майбутній фахівець морського транспорту - необхідно запустити механізм формування психологічної культури, що виключає можливість свідомого порушення правил безпеки мореплавання та підвищує психологічну стійкість членів судового екіпажу в екстремальній ситуації, спричиняє використання ресурсу компетентності в області взаємодії з підлеглими.

\title{
Список використаних джерел:
}

1. Зайцева, Т. Г. (2013). Самоменеджмент психофрізичних станів морських фахівців у контексті посилення людського ресурсу та попередження аварійності на фллоті: навчальний посібник. Херсон: ХДМА.

2. Зайцева, Т. Г. (2009). Психічна культура моряка як фрактор психоемоиійної стійкості моряка. Херсон: ХДМІ.

3. Сорока, О. М. (2019). Практичні рекомендації майбутнім фахівцям морського транспорту щодо самокорекції тривоги та страху перед ймовірними екстремальними ситуаціями професійної діяльності. Науковий вісник Херсонського державного університету. Серія «Психологічні науки», (3), 182-192.

\section{ПСИХОЛОГИЧЕСКИЕ ПОДХОДЫ К ИЗУЧЕНИЮ САМООЦЕНКИ ЛИЧНОСТИ}

\author{
Масловская Олеся Викторовна \\ Национальный исследовательский университет \\ «Высшая школа экономики» \\ РОССИЙСКАЯ ФЕДЕРАЦИЯ
}

Самооценка как психологический феномен рассматривается в массе научных работ. Исследователи в области психологической науки не останавливаются в изучении данного явления, и в результате растет объем публикаций на данную тему. Опираясь на научные источники, в статье будут рассмотрены основные подходы к понятию самооценки личности, а также к ее структуре.

В настоящее время самооценка личности исследована в научных трудах крупнейших психологов, внесших весомый вклад в рассмотрение еe теоретических аспектов. Среди них можно привести в пример, таких исследователей, как Б.Г. Ананьев, Р. Бернс, Л.И. Божович, У. Джеймс, Ф. Зимбардо, И.С. Кон, А.Н. Леонтьев, В.А. Петровский, С.Л. Рубинштейн, Е.Т. Соколова, В.В. Столин, И.И. Чеснокова, С.Р. Пантилеев, Т. Шибутани и другие. 
На вышеуказанной проблеме фокусируют свое внимание как отечественные, так и зарубежные исследователи, пытаясь дать точное определение, а также подвести окончательную черту под тем, что из себя в целом представляет этот феномен. О.Н. Молчанова разделила все теоретические представления о самооценке на 3 группы, где попыталась соотнести пересекающиеся взгляды, и разделить противоположные точки зрения [13].

Первая группа вмещает в себя те теории и исследования, в которых самооценка определена как аффективный компонент Я-концепции, как чувство одобрения или самопринятия. Например, Роберт Бернс предполагал, что самооценка - это принятие себя или аффективная оценка представлений личности о себе самом, которая имеет определенный уровень интенсивности в зависимости от степени принятия тех или иных собственных качеств или характеристик [2]. С.Р. Пантилеев отожествляет данный феномен с эмоционально-ценностным отношением субъекта к себе [15]. Представитель психоаналитического направления 3. Фрейд трактует данное понятие как нарциссическую направленность либидо на себя [19]. В то же время противоположную точку зрения высказывает Э. Фромм, подчеркивая, что истинная любовь к себе является необходимым качеством для принятия других людей [20].

Таким образом, подходы, входящую в данную группу имеют схожесть взглядов на самооценку. На передний план выходит эмоциональное отношение к своему «Я», а также оценочный аспект всех отношений к самому себе. Как отмечает Л.В. Бороздина, при таком взгляде на данную проблему, самооценка как самостоятельный предмет изучения исчезает [4].

Во вторую группу О.Н. Молчанова поместила теории, которые рассматривают самооценку как взаимосвязь между уровнями «Я», а также как регулятор деятельности и поведения личности [13]. Например, В.А. Петровский обращает внимание не только на соответствие реального и идеального «Я», но также на «единомножие Я», например «Я сейчас-Я в прошлом», «Я телесное - Я психологическое», где человек сопоставляя палитру внутренних диалогов разнообразных «Я» выстраивает свое поведение [17]. Соответственно, на передний план выходит регулятивный компонент самооценки, о котором также говорил А. Бандура в теории научения, где поведение индивида зависит от его самооценочной реакции [1].

С одной стороны, сосредоточение внимания на самооценке с точки зрения её регулятивной функции помогает эффективно выстроить коррекционную и консультативную работу, где при воздействии на компоненты «Я» можно сформировать определенное поведение человека. С другой стороны, как утверждает О.Н. Молчанова, самооценка, либо сольется с компонентом самосознания - саморегуляцией, либо потеряет собственную функцию оценки [13].

Третья группа объединяет авторов, которые подчеркивают именно оценочный аспект самооценки, а также рассматривают её как определенный уровень развития самоотношения и самопознания. По мнению И.И. Чесноковой, данный феномен представляет собой результат развития самоотношения и работы самопознания, при этом не сводящийся ни к одному 
из этих компонентов [21]. Л.В. Бороздина под самооценкой имеет в виду оценку индивидом самого себя с точки зрения определенной системы ценностей [4]. Она утверждает, что не самооценка базируется на самоотношении, а наоборот вызывает то или иное отношение к себе самому, будь оно негативным или позитивным. Также в своей более ранней работе С.Р. Пантелеев отмечает, что между понятиями самоотношение и самооценка он не находит концептуальных различий [14].

Данное направление можно охарактеризовать тем, что сюда были помещены именно те теории, которые в своем основании имеют оценочный компонент самооценки, а также рассматривают его через призму самоотношения.

Помимо О.Н. Молчановой подходы к изучению самооценки в своей работе классифицировала М.В. Пастухова [16]. Она приводит следующий перечень:

- Личностный подход рассматривает самооценку в качестве компонента самосознания.

- Структурно-целостный подход предполагает рассмотрение данного феномена как одновременно целостного и многоаспектного образования, которое находится в разных межсистемных связях с другими образованиями психики.

- Деятельностный подход определяет самооценку в качестве фрактора, который влияет на результат деятельности (например, профессиональной).

-Динамический подход рассматривает данное явление в качестве изменяющегося в процессе возрастного развития личности образования.

- Психопатологический подход признает самооценку в качестве критерия психического здоровья индивида.

- Функциональный подход определяет самооценку как основную функцию личности.

А.В. Гайфулин в своей работе обратил внимание на то, что в зарубежной литературе традиционно выделяется 5 основных подходов к пониманию самооценки, которая рассматривается в качестве самоотношения [8]:

- Самоотношение рассматривается как сумма частных самооценок, которые в свою очередь связаны с аспектами Я-концепции.

- Второй подход раскрывает самоотношение как интегральную самооценку субъективно значимых для личности аспектов.

- Третий взгляд на данный феномен несет в себе положение о том, что самоотношение - это иерархическая структура, которая состоит из частных самооценок. А на её вершине располагается обобщенное «Я».

- Также самоотношение рассматривается как самостоятельная малоизменяющаяся переменная, которая сопоставима со своеобразной личностной чертой.

- Самоотношение в ряде работ рассматривается в качестве чувства, которое включает в себя переживания разного содержания.

-Приведенный выше обзор подходов в определении самооценки позволяет понять, насколько сложной и многоплановой является рассматриваемая проблема. 
Если попробовать уйти от обобщающих подходов и выделить отдельные определения, которые были представлены в науке разными авторами, то получится следующая совокупность мнений на один и тот же предмет.

Самооценка - это:

- способность человека составить суждение о ценности и качестве своего поведения, сторон личности [13];

- центральное звено сферы самосознания личности, которое выполняет регуляторную функцию в поведении человека [18];

- дробь, в числителе которой находится успех, в то же время, как в знаменателе - притязания личности, по мнению У. Джеймса [6];

-отражение информации о себе в соотношении с определенными эталонами и ценностями [5];

- когнитивная схема, благодаря которой происходит обобщение прошлого опыта и организация его в новую информацию относительно «Я» [10];

- компонент самосознания личности, рассматриваемый в концепции общения и деятельности [7].

Обобщая вышесказанное, можно заметить, что психологическая наука на данный момент не может дать единого определения данного феномена. Л.В. Бороздина сделала такой вывод, что в зарубежной психологии самооценку рассматривают через призму понятия «Я-концепции», а в отечественной психологии на данную проблему смотрят традиционным взглядом, считая, что самооценка функционирует, как часть самосознания [4].

Несмотря на разрозненность взглядов на понятие самооценки, многие авторы сходятся во мнении о том, какую же структуру она имеет.

А.Н. Леонтьев выделяет в самооценке когнитивный и эмоциональный компоненты, где подчеркивает важность чувственного аспекта, благодаря которому происходит специфическое обобщение эмоций [11]. Такого же мнения придерживается и А.В. Захарова, которая представляет самооценку в качестве двухуровневого образования, куда входят те же самые компоненты [9]. М.И. Лисина отмечает существенные различия между данными аспектами в самооценке [12]. Рациональная часть образа возникает в результате индивидуальной деятельности человека, в то же время аффективный компонент зарождается благодаря опыту общения и взаимодействия с другими людьми. К двум имеющимся структурным составляющим самооценки Л.В. Бороздина и О.Н. Молчанова добавляют оценочный компонент, благодаря которому человек может оценить собственные качества, входящие в структуру его Я [3; 13].

Зарубежные авторы также не оставили без внимания данный вопрос, и обозначили определенные структурные элементы. С. Куперсмит выделяет в структуре самооценки оценочный и аффективный компоненты, также, как и некоторые отечественные психологи [22]. Свою точку зрения описал зарубежный ученый Кристофер Мрук, который разработал двухфакторную модель самооценки, куда входят компетентность и чувство собственной ценности, которые во взаимосвязи между собой обуславливают её динамический характер [23]. 
36 • Problèmes et perspectives d'introduction de la recherche scientifique innovante $\bullet$ Volume 4

Таким образом, проанализировав вышеперечисленную информацию, можно указать на то, что в науке пока нет точного и единого мнения по поводу самооценки, но изучение её по сей день является актуальным. Как зарубежные, так и отечественные авторы трактуют данное явление поразному, приписывая ей определенные структурные компоненты.

\section{Список используемых источников:}

1. Бандура, А. (2000). Теория социального научения. СПб: Евразия

2. Бернс, Р. (2000). Что такое Я-концепция. Психология самосознания. Самара: БАХРАК-М

3. Бороздина, Л. В. (2011). Сущность самооценки и ее соотношение с Я-концепцией. Вестник Московского университета, 1, 54 - 65.

4. Бороздина, Л.В. (1992). Что такое самооценка. Психологический журнал, 4, 99-100.

5. Валицкас, Г.К., Гиппенрейтер Ю.Б. (1989). «Самооценка у несовершеннолетних правонарушителей». Вопросы психологии, 1, 45-54.

6. Векилова, С.А. (2005). История психологии: конспект лекций. М.: АСТ

7. Выготский, Л.С. (2003). Психология развития ребенка. М: Смысл, Эксмо

8. Гайфулин, А. В. (2009). Различные теоретические подходы в определении понятия самооценки. Вестник Томского государственного педагогического университета, 1, 73 76.

9. Захарова, А.В. (1993). Психология формирования самооценки. Минск: Новое знание

10. Кон, С.И. (1978). Открытие «Я». М: Издательство политической литературы

11. Леонтьев, А.Н. (2011). Деятельность. Сознание. Личность. М: Изд-во «Книга по требованию»

12. Лисина, М.И. (1983). Психология самопознания у дошкольников. Кишинев: Штиинца

13. Молчанова, О.Н. (2016). Самооценка: Теоретические проблемы и эмпирические исследования: учебное пособие. М: Флинта

14. Пантилеев, С. Р. (1991). Самоотношение как эмоционально-оценочная система. М: Издво МГУ

15. Пантлеев, С.Р. (2000). Самоотношение. Психология самосознаний. Самара: БАХРАХ - М

16. Пастухова, М.В. (2010). Теоретические аспекты психологического изучения самооценки личности. Известия Самарского научного чентра Российской академии наук, 12, 460- 462.

17. Петровский В.А. (2009). Самоосуществление индивидуальности. В Е.Б. Старовойтенко, В.Д. Шадриков (Ред.), Психология индивидуальности. Новые модели и концепции (с. 221266). М: НОУ ВПО МПСИ.

18. Столин, В.В. (1983). Самосознание личности. М: Издательство Московского университета

19. Фрейд, 3. (2000). Идеал «Я». Психология самосознания. Самара: БАХРАК-М

20. Фромм, Э. (2009). Искусство любить. М: АСТ

21. Чеснокова, И.И. (1977). Проблема самосознания в психологии. М: Наука

22. Coopersmith, S. (1967). The antecedents of self-esteem. San Francisco: Freeman

23. Mruk, C. (1999). Self-Esteem: Research, theory, and practice. New York: Springer 


\title{
СІНЕМАЛОГІЯ ЯК МЕТОД ФОРМУВАННЯ ЖИТТЄСТІЙКОСТІ ПІДЛІТКІВ
}

\author{
Казьмірук Анна Василівна \\ студентка факультету психології, \\ Національний педагогічний університет імені М. П. Драгоманова \\ Науковий керівник: Ставицька С.О. \\ доктор психологічних наук, професор, завідувачка кафредрою загальної \\ і соціальної психології та психотерапії \\ Національного педагогічного університету імені М. П. Драгоманова \\ УКРӒ̈HA
}

Підлітковий вік, на думку американського психолога Стенлі Холла, незвичайний життєвий період, оскільки в ньому концентруються три кризи: психофізіологічна, особистісна та соціальна. Це вік, коли відбувається переорієнтація цінностей i формування ідеалів, перехідний етап між дитинством і дорослістю. I саме тому важливо допомогти підлітку стати сильною та здоровою особистістю, що зможе максимально розкрити та реалізувати свій потенціал, справлятися із життєвими труднощами.

Актуальність роботи зумовлена тим, що молодь $є$ майбутнім держави та світу, і від того, які цінності та сенси будуть закладені у цей сензитивний період, які риси характеру та поведінка будуть сформовані, залежить, чи зможе підліток стати повноцінною здоровою особистістю і реалізовувати свій потенціал.

Новизна роботи полягає у формуванні життєстійкості у підлітків шляхом використання сінемалогії як методу онтопсихології.

Згідно 3 даними дослідження (2016 рік), проведеного Українським інститутом соціальних досліджень, UNICEF і проектом «Здоров'я та поведінкові орієнтації учнівської молоді», 25,4\% українських підлітків мають досвід вживання заборонених наркотичних речовин, 44,8\% принаймні раз у житті вживали алкогольні напої (26,5\% віком 10-17 років були п'яними), 36\% зазнають насильства щонайменше один раз на рік, а $42 \%$ визнали, що хоча б один раз ображали інших. Ці явища зумовлені багатьма чинниками, але можна зменшити або нівелювати їх вплив, якщо допомогти підліткам набути конструктивних навичок та позитивних рис, що стануть їх опорою у скрутних ситуаціях [1].

На нашу думку, однією із таких рис є життєстійкість. Ще у другій чверті XX століття кризові психологи почали шукати «код виживання» [2], який визначає психічне здоров'я людини. Розглядаючи здатність людини протистояти труднощам життя, психологи та фрілософри акцентували увагу на таких поняттях як свобода, свідомість вибору, відповідальність за своє життя і життя тих, хто поруч, знаходження змісту в тому, що відбувається навколо. Віктор Франкл називав це явище «виживанням через віру в себе», «впертістю духу» [3]. Він стверджував, що шанс вижити залежить від ставлення людини до життя, від ії̈ духовної установки в конкретній ситуації, від того, чи має вона справу, «сенс, який хоче реалізувати в майбутньому» [3]. 
Згідно $з$ концепцією С.Мадді [4], структуру життєстійкості складають її компоненти: залученість (упевненість в тому, що навіть у неприємних і важких ситуаціях та стосунках краще залишатися залученим: бути в курсі подій, у контакті з навколишніми людьми, присвячувати максимум своїх зусиль, часу, уваги тому, що відбувається, брати участь у ньому), контроль (переконаність у тому, що боротьба дозволяє впливати на результат того, що відбувається, навіть якщо успіх не гарантовано), прийняття ризику (віра в те, що стреси й зміни - це природна частина життя, що будь-яка ситуація - це, як мінімум, цінний досвід, який допоможе розвинути себе й поглибити своє розуміння життя).

С.Мадді підкреслював важливість вираження всіх трьох компонентів для збереження здоров'я і оптимального рівня працездатності, активності в стресогенних умовах. Дослідник стверджував, що «життєстійкість - не вроджена якість, а формується впродовж життя» [5]. На думку Д.О. Леонтьєва, це «система переконань, яка може розвиватись» [5]. Компоненти життєстійкості формуються в дитинстві і в підлітковому віці. Життєстійкість підлітка починає укріплюватися завдяки його цінностям. У цьому віці активізуються особистісні структури, що пов'язані із компонентами життєстійкості: активний пошук усвідомленості нинішнього життя, розвиток самооцінки на основі свідомої рефрлексії, напрацювання ставлень до різних ситуацій та своїх переживань.

А.Н. Фомінова [6] вказує на те, що у період активного сенсоутворення особистість повинна бути забезпечена психологічними засобами для вирішення вікових криз. Ії̈ дослідження свідчать про те, що бажання підлітка вдосконалюватися залежить від певних образів-стимулів. Для 25\% респондентів - це ідеальні образи (герої кінофрільмів та книг), для $25 \%$ спілкування 3 конкретними людьми, для 30\% - жорсткі соціальні вимоги дорослих, для $20 \%$ - внутрішній стан («резерви душі», «почуття впевненості» і т.п.). Найбільш актуальними питаннями цього періоду, на думку опитаних підлітків, є:

- напрацювання вміння вирішувати внутрішні конфлікти у діяльності, а не на рівні пасивного спостереження та невротичної рефрлексії;

- розвиток емоційного проникнення у ситуацію, що впливає на її осмислення;

- пошук варіантів відходу від «сценаріїв» впливу на інших людей;

- розширення свідомості як умова вирішення нагальних питань.

Оскільки нині кіно - це найбільш розповсюджений і наймогутніший засіб комунікації у світі [7], оптимізувати вирішення наведених вище проблем можна за допомогою сінемалогії. Це метод онтопсихології, що $є$ дозволяє виявити неусвідомлені конструкти особистості за допомогою їх проекції на фрільм. За словами засновника методу Антоніо Менегетті, це аналіз, що дає змогу відстежити і втілити в історії автентичність людини.

Робота за цим методом складається із трьох етапів:

1. Ознайомлення з темою, перегляд фільму.

2. Аналіз учасниками своїх переживань, відповіді на поставлені ведучим питання.

3. Зворотній зв'язок. 
Завдання учасників полягає у намаганні зрозуміти фрільм на таких рівнях: продемонстрована проблема персонажа, варіанти ії̈ вирішення, використані у фільмі символи та їх можливі інтерпретації.

Переглядаючи фільм із чітко поставленою метою та відповідаючи на навідні питання, підлітки зможуть краще пізнати себе, напрацювати конструктивні способи виходу зі стресових ситуацій, намітити ціннісні орієнтації і смисли, розвинути навички реслексії та емпатії.

Ми вважаємо, що для реалізації даної мети найкраще використовувати такі фрільми: «Мирний воїн» (2006; Німеччина, США), «1+1 (Недоторканні)» (2011; Франція), «Заплати іншому» (2000; США), «У погоні за щастям» (2006; США), «Подорож Гектора у пошуках щастя» (2014; Великобританія), «Траса 60» (2002; США, Канада) тощо.

Наприклад, кінострічка Віктора Сальви «Мирний воїн» - це історія про студента-спортсмена Дена, який має здавалось би нездійсненну мрію, та його наставника Сократа, що допомагає йому пройти нелегкий шлях саморозвитку. Спочатку Ден постає перед глядачем як уособлення роздутого Ego, але поступово відбувається його індивідуація, він вчиться прислухатися до себе, своїх думок і прагнень, підвищується рівень його свідомості. Ми можемо спостерігати за тим, як нищаться звичні йому шаблони, як працюють захисні механізми, як він переживає травму і відновлює внутрішню цілісність, як приходить до усвідомленого вибору та досягає успіху.

Цю стрічку можна аналізувати як фрагментарно, тобто епізодами, так i цілісно.

Для роботи з фільмом ми пропонуємо взяти такі епізоди.

І. Ден поступово змінює свої цінності, розвивається, через це старе оточення більше не приймає його.

Приклад запитань для обговорення:

- Чи знайома Вам така ситуація?

- Які думки та емоції вона у Вас викликає?

- Чому оточення перестало приймати Дена?

- Як би Ви вчинили на місці Дена?

- Що на Вашу думку краще: намагатися завоювати авторитет «старого» оточення чи шукати нових друзів?

II. Ден сильно травмує ногу, а тому більше не може тренуватися. Відчуває жалість до себе та потяг до самогубства, але переборює негативні емоції і починає жити заново.

Приклад запитань для обговорення

- Чи доводилося Вам бачити або переживати подібні ситуації?

- Чи знайомі Вам такі відчуття?

- Чи траплялося Вам або вашим знайомим виходити із подібного стану конструктивно?

- Що Вам допомагало або могло б допомогти впоратися із цією ситуацією?

На нашу думку, ці та подібні епізоди допоможуть підлітку навчитися відрефлексовувати власні почуття, більш свідомо приймати життєві ситуації, розуміти свою позицію, цілеспрямовано діяти для досягнення мети та сфрормувати життєві цінності. 
40 - Problèmes et perspectives d'introduction de la recherche scientifique innovante $\bullet$ Volume 4

Висновки. Кінематограф в цілому та сінемалогія зокрема, при оптимальному підборі фрільмів і конструктивному обговоренні $\epsilon$ одним із ефективних способів усвідомити та систематизувати життєвий досвід, поглянути на ситуацію з боку. Образи героїв, з якими підлітки можуть себе ототожнювати, відіграють велику роль у знаходженні життєвої опори, а також сприятимуть росту та розвитку їх особистості.

\section{Список використаних джерел:}

1. Закусило, О.Ю., Калініна, А.В., Кириченко, В.І. \& Лютий, В.П. (2017). «Програма 15»: метод.посібник (з питань профрілактики ВІЛ-інфрекиії та підтримки психосоціального здоров я в Україні). Київ: Український фонд «Благополуччя дітей».

2. Пергаменщик, Л.А. (2013). Психологический код выживания Ивана Денисовича Шухова. Консультативная психология и психотерапія, (3), 6-9.

3. Франкл, В. (1990). Человек в поисках смысла. Москва: Прогресс.

4. Бабатіна, С. І. (2012). Особливості взаємозв'язку життєстійкості з темпоральними характеристиками особистості студента. Актуальні проблеми державного управління, педагогіки та психології: зб. наук. праць Херсонського національного технічного університету, (6), 437-441.

5. Леонтьев, Д.А., Рассказова, Е.И. (2006). Тест жизнестойкости. Москва: Смысл.

6. Фоминова, А.Н. (2012). Жизнестойкость личности. Москва: Прометей.

7. Менегетті, А. (2001). Кино, театр, бессознательное. Москва: ННБФ «Онтопсихология».

DOI 10.36074/29.11.2019.v4.06

\section{СКЛАДОВІ ЖИТТЄВОГО УСПІХУ ОБРАЗІВ ВІДОМИХ ОСОБИСТОСТЕЙ}

Носова Олена Володимирівна

здобувач вищої освіти фракультету соціології Київський національний університет імені Тараса Шевченка

Науковий керівник: Бабенко Світлана Сергіївна канд. соціол. наук, доцент кафедри соціальних структур та соціальних відносин Київський національний університет імені Тараса Шевченка УКРӒ̈̈А

Проблемна ситуація. Кожну особистість цікавить ії власний успіх. Успіх уже давно зайняв одне з центральних місць у рейтингу життєвих цінностей як окремої людини, так і суспільства в цілому [6]. Тому цілком закономірно, що ця проблема привертає до себе значну увагу з боку соціальних наук. На формування уявлень про життєвий успіх впливає ситуація в самому суспільстві, його культура. Сучасне суспільство характеризується зміною ціннісного простору і, відповідно, уявлень населення про соціальний успіх та легітимні способи й стратегії його досягнення.

Слава і популярність завжди відігравали важливу роль в житті суспільства, а сьогодні прагнення до слави стало одним з основних мотивів поведінки 
людей. Популярність у сучасному світі стає все більш привабливою, а конкуренція за неї постійно зростає. Засоби масової інформації присвячують зіркам левову частку своїх ресурсів.

Зазначене виділення людей завдяки популярності здатне прямо або побічно підвищувати соціальні характеристики людини і надавати їй додаткові блага в групі людей, які володіють аналогічними якостями.

Під відомістю (популярностю) розуміється інфрормація про людину (групу, об`єкта), яка виділяє його - щодо поширеності інформації про нього або в якихось інших сенсах - із загального ряду людей (груп, об`єктів), що володіють аналогічними професійними чи соціальними якостями, тобто досягла суспільно визнаного успіху [4].

Але звідси постає питання. Яким чином інформація про певну особливу людину проникає та поширюється в масах? На це питання може дати відповідь теорія конструктивізму. Основною роботою в даній теорії вважається «Соціальне конструювання реальності» П. Бергера і Т. Лукмана. Головна теза визначено ще в її назві: реальність соціально конструюється. Автори визначають «реальність» як «якість, властиве феноменам, мати буття, незалежне від нашої волі і бажання», «знання» як «впевненість в тому, що феномени є реальними і мають специфічні характеристиками» [3]. Іншими словами наша реальність складається з того, що ми знаємо, відповідно, якщо ми не володіємо знаннями про що-небудь, значить, воно не входить в рамки нашої реальності.

Що ж є інструментом створення цієї інформації, яка конструює суспільну реальність? Це ЗМК. Ще у 1948 р. Р. Лассуелл виділив три основні функції масової комунікації: 1 . огляд навколишнього світу, що можна інтерпретувати як інформаційну функцію; 2. кореляція з соціальними структурами суспільства, які можна тлумачити як вплив на суспільство та його пізнання; 3. передача культурної спадщини [1]. Це журнали, газети, телебачення тощо, та кінематограф.

Кіно розуміється кінофреноменологами як мистецтво, яке рухається, його сутність вбачається в копіюванні реальності, а саме дистиляції прекрасного 3 реальності і репрезентації реальності. Копія життя, як говорять про кіно кінофеноменологи, абстрагована, i, таким чином, вона претендує на передачу життя, отже, кіно, на їхню думку, відтворює те, що «є насправді». Паралельно з апеляцією до відтворюваності, кінофреноменологи об`єктивують кіно, тобто виключають суб єкта із сфери кіномистецтва. Таким чином, реальність представлена як сукупність об`єктів спостереження. У цьому полягає гіперфункція: реальність вилучається з власної сфери і відтворюється на матеріальному носії. Теорія репрезентації редукує кіно до копіювання реальності «на плівку» [2].

Тобто кінематограф є відображенням переломленної соціальної дійсності, але переломлення тут не означає спотворення, просто саме на великому екрані сучасне «суспільство спектаклю» і знаходить своє належне вираження. «Спектакль - це суспільні відносини між людьми, опосередковане образами ... це світогляд, що став дієвим і вираженим матеріально. Це об`єктивація бачення світу» [5].

Виникає наступне питання, яке вже безпосередньо потребує дослідження 
(дослідницька проблема): як же зображуються відомі особистості в кінематографрі, та чим ці зображення відрізняються у вітчизняному та зарубіжному кінематографрах? Чим відрізняються, а чим схожі ці образи?

Відповідно об`єктом дослідження є особливості представлення образів відомих особистостей в зарубіжному та вітчизняному кінематографах. Емпіричним об`єктом $€$ біографрічний фільм масового художнього характеру. Предмет: особливості зображених характерних рис та ознак образів відомих особистостей у зарубіжному та вітчизняному кінематографрах. Мета: порівняльна характеристика особливостей зображених характерних рис та ознак образів відомих особистостей у зарубіжному та вітчизняному кінематографрах.

Обґрунтування джерела. Як було зазначено в проблемній ситуації кіно здатне транслювати аудиторії певні образи чи ситуації суспільної реальності, отже, й відображувати життєвий шлях (біографрічну інформацію) чи його частини певної особистості, яку суспільство визнає відомою. Кінематографр $є$ не лише інструментом трансляції аудиторії певних ціннісних установок, а й способом відображення соціальної реальності з можливістю викривлення ії $\mathrm{y}$ бік, який є більш прийнятним для аудиторії. Отже, дослідження зображення реальних відомих особистостей у кінематографрі дозволяє виявити, якими ж рисами та ознаками має, на думку аудиторії, володіти особистість для того, щоб досягти визнання та слави.

Отже, для контент-аналізу були вибрані саме біографічні фрільми, але не документальні, а ті, які орієнтовані на не специфічну, а більш глобальну аудиторію, тобто фрільми масові та художні.

В аналізі такого типу важливим $€$ не достовірність біографрічної інформації та точного показу головного героя (відомого індивіда), а саме: як аудиторія, на яку даний фільм зорієнтований, розуміє категорію слави та успіху та які критерії пов язує із поняттям «відомі люди». Визначити, що для більшості індивідів ці цінності, методи, світогляд тощо, що зображені у фрільмі, співвідносяться із уявленням індивідів образу відомої особистості, можна завдяки популярності та оцінкою цього фрільму аудиторією.

Адже фрільми ніяк не можуть набувати популярність, якщо аудиторія їх не сприймає (тобто, якщо фрільм не відображає зрозумілі та загальновизнані у суспільстві цінності, він тоді не може бути зрозумілим для неї, отже, й не може бути популярним та мати високі оцінки глядачів), то й відбирати фільми слід за рейтингом популярності, тобто оцінками на відомих та офріційних Інтернетресурсах, що займаються розповсюдженням та надають можливість глядачам оцінювати фільми.

Процес фрормування вибірки має такий вигляд:

1. для зарубіжних фрільмів: було використано рейтинг популярних біографічних фільмів (за оцінками глядачів) на сайті: https://www.imdb.com/list//s066667581/ (перших 30 у рейтингу фільмів), та

2. для вітчизняних: оскільки такого рейтингу популярних біографрічних фрільмів українського виробництва нема, то береться загальний рейтинг популярності за оцінками на сайті imdb (щоб вибірка була сконструйована, як й у випадку із зарубіжними фрільмами) та вже з них відбираються ті, які можна віднести до біографрічних (перші 30 у сформованому рейтингу). 
Одиницею аналізу є не один певний біографічний фільм, а, оскільки фіксація одиниць обрахунку стосувалася лише одного образу кожного фрільму (головного героя), було прийнято рішення зробити групування вибіркової сукупності за ознакою «Країна-виробник». Тобто у даному дослідженні використані за одиниці аналізу: 2 групи фрільмів (вітчизняного та зарубіжного виробництва).

Загальна концептуальна схема дослідження, що зображує логіку створення ознак та їх поділу на категорії для подальшого аналізу, представлено на рис 1.

У дослідженні було використано кодифрікатор, що містив 27 категорій та набір субкатегорій до них. Створений даний кодифікатор прагматичним шляхом, тобто на основі уявлень дослідника щодо складових елементів загального образу героя і категорій.

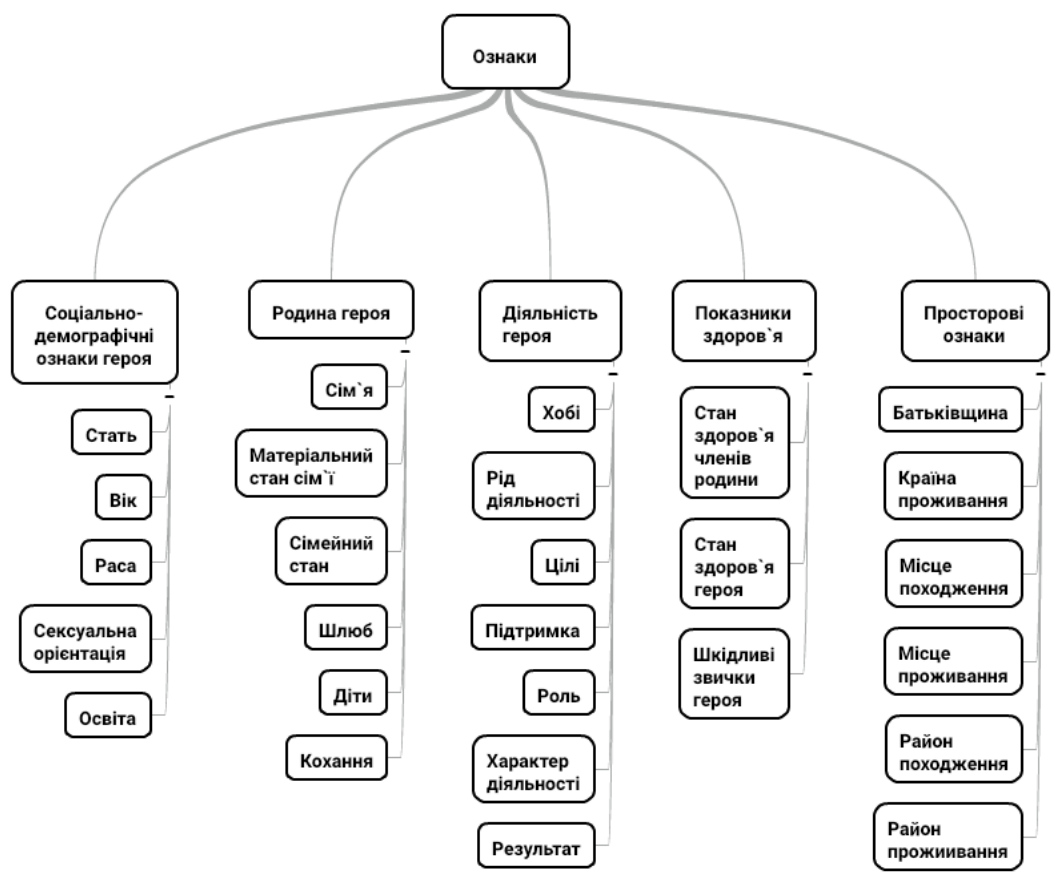

Рис 1. Концептуальна схема контент-аналізу

Результати аналізу та висновок. У даному дослідження була здійснена порівняльна характеристика особливостей зображених характерних рис та ознак образів відомих особистостей у зарубіжному та вітчизняному кінематографрах. Отже, мета дослідження була досягнена.

Була застосована конструктивіська теорія - наукова парадигма, згідно якої соціальна повсякденна реальність, її розуміння та сприймання індивідом $\epsilon$ нав`язаною йому ззовні в процесі його комунікації із іншими представниками 
певного суспільства. Масова культура та, в нашому випадку, кінематограф, $є$ одним із методів конструювання реальності. Мас-медіа репрезентують публічну сферу, що забезпечується певними тематичними знанням. Життєвий успіх не $є$ винятком, уявлення, що таке успіх також транслюється й конструюється нами через призму ЗМК та ЗМІ.

У сучасному толерантному суспільстві, все ще $є$ місце стереотипам та упередженням. Так, завдяки даному дослідженню, можна узагальнити дані, отримані з аналізу та побачити чіткий «ідеальний» штучно сконструйований образ відомих та, отже, успішних особистостей такими, якими вони мають бути з точки зору переважної більшості.

Отже, дати певною мірою аргументовану відповідь на запитання: «Якими ж $\epsilon$ відомі особистості та як вони висвітлюються у зарубіжних та вітчизняних фільмах?» - можна, створивши на основі всіх показників, які були отримані в результаті дослідження, збірний образ.

У зарубіжних фільмах це переважно «білі» чоловіки юного віку (21-25 років) традиційної орієнтації. Освіта не $є$ важливою для того, щоб стати відомим та досягти успіху. Мають живих та здорових батьків. Народилися на території однієї із країн сучасного Європейського Союзу в сім 'ї, яку можна віднести до середнього класу. Переважно вони $є$ громадянами США, проживають у благополучних районах міст. Вони здорові, але курять та вживають алкоголь. Ці чоловіки мають щасливе та взаємне кохання. Одружені лише один раз, у шлюбі панує рівноправ'я та вірність, не мають дітей. Працюють у сфері політики чи бізнесу, їх підтримують, як близькі люди, так і чужі люди, що мають яке-небудь відношення до їхньої сфери діяльності. У вільний час вони надають перевагу активному відпочинку. Їх можна назвати борцями та героями, вони думають про інших (є альтруїстами), також прагнуть самореалізуватися у вибраній ними сфрері та задовольнити власні амбіції та досягти своєї мрії, що в них і виходить.

Досить схожий образ виникає після перегляду також вітчизняних фільмів. Тут теж успішною та відомою особистістю представлено «білого» чоловіка, але зрілого віку і традиційної орієнтації. Тут вища освіта вже є суттєвою й у відомих особистостей вона має бути вищою. Теж мають живих та здорових батьків. Народилися в Україні у невеликих поселеннях (селищах міського типу). Матеріальний стан їхньої батьківської родини не грає суттєвої ролі. Проживає в Україні, але інформації щодо точного типу населеного пункту немає, відомо лише, що вони можуть жити як в благополучних, так i в неблагополучних районах. Як і у зарубіжних фільмах, вони здорові, але курять та вживають алкоголь, також мають щасливе та взаємне кохання. Вони так само одружені лише один раз, у шлюбі панує рівноправ'я та вірність, але інформації щодо наявності чи відсутності дітей немає. Переважна більшість з них працює у військовій сфері, але їх теж визнають та підтримують як близькі люди, так і чужі люди, що мають яке-небудь відношення до їхньої сфери діяльності, а у вільний час українські відомі особистості так само надають перевагу активному відпочинку. Вони теж $є$ борцями та героями, вони думають про інших (є альтруїстами), але прагнуть не самореалізування у вибраній ними сфрері, а допомогти (врятувати) іншим людям та теж виконати власну мрію, що в результаті у них і виходить. 
Бачимо, що образи є досить схожими, але все ж можемо виявити характерні особливості у вітчизняних і зарубіжних фрільмах (див. таб. 1).

Таблиця 1

\section{Особливості у зображені відомих особистостей у зарубіжному та вітчизняному кінематографрах}

\begin{tabular}{|c|c|}
\hline Герої у зарубіжному кінематографрі & Герої у вітчизняному кінематографі \\
\hline \multicolumn{2}{|c|}{ Вік (за шкалою Еріксона) } \\
\hline Юні героя & Герої зрілого віку \\
\hline \multicolumn{2}{|c|}{ Освіта } \\
\hline Невказана & Вища освіта \\
\hline \multicolumn{2}{|c|}{ Просторове походження } \\
\hline $\begin{array}{c}\text { Країна ЄС, тип населеного пункту не } \\
\text { вказується }\end{array}$ & Україна, селище мійського типу \\
\hline \multicolumn{2}{|c|}{ Класове походження } \\
\hline Середній клас & Невказане \\
\hline \multicolumn{2}{|c|}{ Місце проживання } \\
\hline $\begin{array}{c}\text { США, місто-мільйонник, благополучний } \\
\text { район }\end{array}$ & $\begin{array}{c}\text { Україна, посленння або місто, район } \\
\text { переважно невказаний }\end{array}$ \\
\hline \multicolumn{2}{|l|}{ 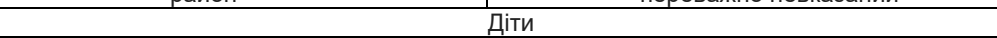 } \\
\hline Не мають дітей & Інформація невказана \\
\hline \multicolumn{2}{|c|}{ Тривалість шлюбу } \\
\hline Менше 5 років & Більше 10 років \\
\hline \multicolumn{2}{|c|}{ Рід діяльності } \\
\hline Бізнес або політика & Військова справа \\
\hline \multicolumn{2}{|c|}{ Ціль героя } \\
\hline Самореалізуватися & Допомогти іншим \\
\hline
\end{tabular}

\section{Список використаних джерел:}

1. Lasswell, Harold Dwight. (1948). The Structure and function of communication for society. The Communication of Ideas: Harper and Brothers. Вилучено 3 https://pracownik.kul.pl/files/37108/public/Lasswell.pdf;

2. Базен, А. (1972). Что такое кино? М.: Искусство.

3. Бергер, П. \& Лукман, Т. (1995). Социальное конструирование реальности. Трактат по социологии знания. М.: «Медиум».

4. Гринин, Л. Е. (2010). Психология и социология феномена славы Историческая психология и социология истории, ( 2), 98-124;

5. Дебор, Г. (2000). Общество спектакля. М.: Логос.

6. Кейри, Б. (2006). Психологи задумались, почему людям нужна слава. The New York Times 11 сентября. Вилучено 3: http://www.inauka.ru/psychology/ article67455.html. 


\title{
SECTION X. \\ COMMUNICATIONS SOCIALES ET CULTURE
}

DOI 10.36074/29.11.2019.v4.07

\begin{abstract}
L'IMPACT DU TOURISME GASTRONOMIQUE SUR LA FORMATION DES DERNIËRES TENDANCES DU TOURISME CULTUREL
\end{abstract}

ORCID ID: 0000-0003-4771-4521

Stepan Ditchkovski

Candidat des sciences pédagogiques, docent

Directeur de l'Institut d'études culturelles pratiques et de gestion l'art

Académie nationale des Gestion de la culture et des arts

ORCID ID: 0000-0001-6187-6215

Sergei Ivanov

Docteur en sciences chimiques, professeur

Le premier vice-recteur pour le travail scientifique et pédagogique

Académie nationale des Gestion de la culture et des arts

UKRAINE

Le monde moderne est dans un état de transformation paradigme, dont l'algorithme est incertain et imprévisible. L'affrontement civilisationnel et culturel dans les démocraties occidentales entraîne une perturbation du système d'interaction des communautés multiculturelles qui, au cours des millénaires, ont établi les coutumes et les traditions d'une interaction accueillante optimale à la suite du dialogue interculturel. Le rétablissement de l'équilibre perdu doit devenir un impératif de la politique humanitaire moderne. L'un des moyens de cette restauration est de cultiver un environnement dans lequel une véritable hospitalité prospérera [1]. Dans le Tourisme, l'individu «se détache " du confort domestique habituel, de la vie quotidienne, du style de vie, limite consciemment le nombre de choses qu'il utilise, autrement qu'à la maison, il mange et autres. Pendant le voyage, une personne éprouve une sorte d'inconfort que l'hospitalité doit compenser et remplacer par un sentiment de nouveau confort. Selon la Philosophie de I'hospitalité," l'autre "devrait créer pour le" voyageur "des conditions dans lesquelles il ne se sentirait pas "étranger", "étranger", "rejeté" [2]. Aujourd'hui le tourisme développé conjugue la mondialisation et la valeur des ressources locales. Le monde devient de plus en plus ouvert, cependant, les touristes recherchent de nouvelles expériences basées sur l'identité et la culture locales. Aujourd'hui, les touristes veulent ressentir la véritable authenticité - la cuisine locale, la cuisine des habitants, dans leur propre maison. Peer-to-peer dining-invitation à la table, familiarité avec la cuisine nationale, Master classes de cuisine, visites gastronomiques [3]. On sait que chaque peuple a sa propre cuisine nationale, qui fait partie intégrante de la culture nationale. L'histoire séculaire de la cuisine, les traditions nombreuses et variées dans la culture gastronomique de chaque peuple, les caractéristiques culinaires régionales, est sans aucun doute la ressource la plus riche pour la formation et le développement réussi dans n'importe quel pays du tourisme gastronomique. Ces dernières années, il est devenu l'un des types de 
tourisme les plus dynamiques et créatifs, ce qui forme de nouveaux types d'établissements d'accueil et favorise la diversification du tourisme local, régional et National [4].

Dans la littérature scientifique, la gastronomie a longtemps été considérée comme un élément. Le concept 'Tourisme gastronomique' est apparu relativement récemment - en 1998, pour exprimer l'idée que les gens apprennent d'autres cultures à travers la nourriture locale. À ce jour, le terme est devenu universellement utilisé dans la formation d'un produit touristique dans de nombreux pays du monde, et le concept de "touriste culinaire" est considéré comme une catégorie démographique distincte [5]. Étant le résultat de la fusion des caractéristiques naturelles, sociales et culturelles du territoire, le Tourisme gastronomique permet de répondre aux besoins des touristes pour une expérience authentique, sentir «l'esprit du territoire», se familiariser avec la culture locale et la vie quotidienne à travers les traditions culinaires [6].

Dans le modèle de préférence gastronomique les touristes proposés par des chercheurs étrangers, il existe 4 types de touristes: le touriste gastronomique existentiel est à la recherche d'expériences gastronomiques dans le but d'acquérir des connaissances sur la cuisine et la culture locales et régionales; il évite les restaurants à la mode célèbres et préfère visiter les fermes et les vignobles, participer à des ateliers culinaires, etc.; ses préférences gastronomiques correspondent au style de vie général, à la mode et à l'actualité; un touriste gastronomique vacancier est à la recherche d'aliments et de boissons familiers; c'est un type de voyageur plus conservateur qui mange souvent seul et évite les restaurants de luxe; pour lui, la gastronomie ne joue pas un rôle important pendant le voyage; un touriste gastronomique; ce type de touriste visite des restaurants à chaîne bon marché, où l'accent n'est pas mis sur la qualité, mais sur la quantité de nourriture [7].

Voyager dans une région gastronomique à des fins récréatives ou récréatives comprend la visite de producteurs alimentaires primaires ou secondaires, de festivals gastronomiques, d'expositions et d'événements alimentaires, de foires, de spectacles et de démonstrations culinaires, de dégustations ou de toute autre activité liée à la nourriture. Cette visite comprend également l'étude des différentes cultures, l'acquisition de connaissances par la consommation des plats dans la région, la familiarisation avec la cuisine nationale du pays, les particularités de la production et de la préparation des aliments et des plats, ainsi que la formation et l'amélioration des connaissances professionnelles. Ainsi, le Tourisme peut être considéré comme gastronomique si tout ce qui précède est la principale raison ou la motivation de voyager vers un endroit particulier ou au moins l'une des raisons essentielles. Mais aujourd'hui, même si la gastronomie n'est pas la principale raison du voyage, elle joue un rôle de plus en plus important en tant que motivation secondaire ou partielle des touristes.

Les caractéristiques distinctives du Tourisme bistronomique comprennent non seulement ses objets, mais aussi le fait que les conditions pour son développement ont absolument tous les pays, et c'est une caractéristique unique de ce type de Tourisme; pour toute période de l'année, il est possible de choisir une visite appropriée; le Tourisme gastronomique à un degré ou à un autre est un élément 
La gastronomie touristique offre l'occasion de revitaliser et de diversifier le Tourisme culturel, car il incarne simultanément les valeurs traditionnelles et les nouvelles tendances dans la société moderne: respect de la culture locale, mode de vie sain, authenticité, durabilité. Ce rôle de premier plan de la gastronomie dans le choix de l'orientation du voyage a conduit à la croissance sur le marché touristique des offres gastronomiques basées sur des produits locaux de haute qualité. En effet, cette branche de l'économie est difficile à exporter grâce à un lien fort avec les traditions locales et les ressources du territoire. II est possible d'exporter des produits gastronomiques prêts à l'emploi, mais il est presque impossible de transporter l'environnement nécessaire à sa production, les connaissances et l'expérience des personnes impliquées dans la préparation des plats et les traditions culinaires [9].

La gastronomie est un élément-clé de toutes les cultures et joue actuellement un rôle important dans l'expérience touristique. Les touristes recherchent de plus en plus le contact avec les habitants et leur vie, l'expérience de la cuisine nationale, la Promotion de la production d'excellents produits, le développement d'infrastructures pour la production et la consommation de produits alimentaires et le soutien des traditions culturelles locales. Dans ce processus, la gastronomie permet aux visiteurs de créer plutôt que de consommer. Le territoire local est la base des propositions gastronomiques c'est un élément qui est la source de l'identité locale. II comprend le paysage, l'environnement, l'histoire, la culture, les traditions. De ce point de vue, transformer le territoire en un paysage culinaire est l'une des tâches de la destination touristique. II est important de déterminer quelles ressources naturelles et culturelles peuvent être transformées en un produit touristique par lequel un territoire peut être identifié. Aucune offre gastronomique touristique ne sera viable si elle n'est pas en mesure de prendre en compte les caractéristiques culturelles du territoire. La gastronomie permet aux touristes d'accéder au patrimoine culturel et historique, de se rapprocher de la culture de manière expérimentée plutôt que de simplement contempler.

\section{Les références:}

1. Pilipiv, V. V. (2018). Aspects philosophiques et culturels du phénomène hôtelier. Touveaux internationals: études culturelles, philologie, musicologie (Éd. I(10)., p. 47-51). Kyiv: Millénium.

2. Garbar, G. (2013). Philosophie de l'hôtellerie dans l'espace ukrainien du tourisme. Religion et société. 3-4 (11-12), 43-48.

3. Tendances modernes dans l'hôtellerie. Retrieved from http://www.wtmlondon.com/RXUK/RXUK_WTMLondon/2015/documents/.

4. Grbac, B. \& Milohanović, A. (2008). Contribution of Food Products in Creating Cultural Identity of Tourist Destination. WSEAS International Conference on Cultural Heritage and Tourism. Heraklion (p. 83-88), July 22-24, Crete Island, Greece.

5. Su, C. S. \& Horng, J. S. (2012). Recent Developments in Research and Future Directions of Culinary Tourism: A Review. M. Kasimoglu (Ed.). Visions for Global Tourism Industry - Creating and Sustaining Competitive Strategies.

6. Lin, Y.-C., Pearson, T. E. \& Cai, L. A. (2011). Food as a Form of Destination Identity: A Tourism Destination Brand Perspective. Tourism and Hospitality Res, (11), 30-48.

7. Kivela, J. \& Crotts, J. C. (2006). Tourism and Gastronomy: Gastronomy's Influence on How Tourists Experience a Destination. J. Hospitality and Tourism Res, 30(3), 354-377. 
8. Sitcheva, V. O. \& Chpenkova, K. S. (2014). Conditions pour le développement du tourisme gastronomique en Russie et dans le monde. Concept, (7). Retrieved from https://cyberleninka.ru/article/n/usloviya-razvitiya-gastronomicheskogo-turizma-v-rossii-i-v-mire.

9. Blakey, C. (2012). Consuming Place: Tourism's Gastronomy Connection. HOHONU, (10), 51-54.

DOI 10.36074/29.11.2019.v4.08

\section{ВИКЛИКИ ДУАЛЬНОЇ ОСВІТИ: РОЗРОБКА СТРАТЕГІЇ НАВЧАННЯ (НА ПРИКЛАДІ ІВЕНТ-МЕНЕДЖМЕНТУ, КНУКІМ)}

Пархоменко Ірина Ігорівна

канд. філос. наук, ст. викладач факультету івент-менеджменту та шоу-бізнесу Київський національний університет культури і мистецтв

УКРÄ̈HA

Наразі в Україні відбувається активний процес реформування сфери освіти, однією із цілей якого $є$ напрацювання ефективної взаємодії між бізнесом, урядовими установами, соціокультурними інституціями та університетами. Мета взаємодії - налагодження діалогу і співпраці щодо підготовки студентів - майбутніх фрахівців, які отримують практико-орієнтовані знання і можуть конкурувати з іноземними випускниками на ринку праці. Тому, університети починають реалізувати проекти дуальної освіти, що $\epsilon$ безпосереднім розпорядженням Кабінету Міністрів України і відображено у «Концепції підготовки фахівців за дуальною формою здобуття освіти» (2018) [1].

Одним із таких університетів є Київський національний університет культури і мистецтв, де вже другий рік поспіль на факультеті івентменеджменту та шоу-бізнесу реалізують проект навчання з дуальною освітою [2]. Проект стартував минулого року на спеціалізації «Івент-менеджмент», спеціальність 034 Культурологія. Реалізуючи проект другий рік, постає необхідність розробки Стратегії навчання професійним компетенціям сучасних івент-менеджерів, головними стейкхолдерами у розробці якої мають бути як викладачі-теоретики, так і практики, запрошені з індустрії.

Приклад навчання івент-менеджерів цікавий тим, що в Україні вперше спробували здійснити навчання таких фахівців в межах формальної освіти. Більше того, щоб говорити про Стратегію навчання професійним компетенціям необхідно розуміти про які компетенції йде мова та яким чином цим компетенціям слід навчати. Адже механізм засвоєння як на теоретичних заняттях, так і на практичних - потім відіграє ключову роль у відтворенні і застосуванні студентом знань і вмінь під час безпосередньої роботи. У випадку з івент-менеджером потрібно також врахувати, що мова йде про креативну роботу або creative work (термінологія Джона Хокінза). Те, яким чином засвоюється знання $€$ викликом для теоретиків і практиків одночасно. Адже недостатньо просто передати знання в певній готовій формі. Така передача автоматично призводить до втрати цінності у студента як споживача. Цю тезу частково підтверджує перелік загальних компетенцій від Інституту майбутнього, США [3]. Наприклад, критичне мислення формується внаслідок 
синтезу і аналізу багатьох складових, і не може бути засвоєним внаслідок прочитання деякого параграфуу з книжки.

Отже, на першому етапі розробки Стратегії навчання професійним компетенціям сучасних івент-менеджерів $€$ необхідність сформувати перелік професійних компетенцій. Досліджуючи це питання, було з'ясовано, що світова івент-індустрія керується спеціальним довідником Event management book of knowledge або ЕМВОК. Це звід знань і вмінь, які формують основу професії івент-менеджера. Одними із розробників потрібно вважати науковців: В.О'Тулла, Дж.Голдбата та Г.Боудіна. Робота над ЕМВОК тривала з 1999 до 2003 року. В 2004 році перелік професійних компетенцій івент-менеджера почали презентувати на міжнародних конференціях у вигляді трирівневої моделі, яка складалася з класів (domains), етапів роботи над івентом (phases) та процесів (processes) (Табл.1.) [4].

Таблиця 1

Трирівнева модель професійних компетенції івент-менеджера

\begin{tabular}{|c|c|c|}
\hline Сфера знань & $\begin{array}{c}\text { Етапи роботи } \\
\text { над івентом }\end{array}$ & Процеси \\
\hline $\begin{array}{c}\text { Адміністрування - фрінансовий менеджмент, HR- } \\
\text { менеджмент, закупівлі, інформаційний супровід, } \\
\text { тайм-менеджмент, робота зі стейкхолдерами, } \\
\text { системами }\end{array}$ & \multirow{5}{*}{$\begin{array}{c}\text { ініціація } \\
\text { планування } \\
\text { імплементація } \\
\text { проведення } \\
\text { постсупровід }\end{array}$} & \multirow{5}{*}{$\begin{array}{c}\text { комунікація } \\
\text { документування } \\
\text { моніторинг } \\
\text { відбір } \\
\text { оцінка }\end{array}$} \\
\hline $\begin{array}{c}\text { Дизайн - розробка контенту івенту, підбір } \\
\text { теми, підготовка програми, дизайн локації, } \\
\text { розваги, кейтирінг }\end{array}$ & & \\
\hline $\begin{array}{c}\text { Маркетинг - підготовка маркетингового плану, } \\
\text { матеріалів, мерчів - товарів з символікою івенту, } \\
\text { промоція, PR, продажі, підтримка спонсорів та } \\
\text { партнерів }\end{array}$ & & \\
\hline $\begin{array}{l}\text { Операції - робота з відвідувачами на івенті, } \\
\text { комунікації, інфрраструктура, логістика, учасники, } \\
\text { місця, техніка } \\
\end{array}$ & & \\
\hline $\begin{array}{c}\text { Ризики - гнучкість, ефрективні рішення, } \\
\text { надзвичайні ситуації, безпека здоров'я, } \\
\text { страхування, знання законів і прав, безпека }\end{array}$ & & \\
\hline
\end{tabular}

взято з [4]

Потрібно зауважити, що етапи роботи над івентом та процеси наскрізно пов'язані між собою. При цьому під «процесами» розуміють сукупність інструментів, які будуть використані івент-менеджером на різних етапах роботи над івентом.

Однак, потрібно розуміти, що вищеперераховані професійні компетенції івент-менеджера було сформовано ще у 2004 році, і сфера івент-менеджменту активно змінюється під впливом різноманітних фракторів. Тому, в розробці Стратегії навчання професійним компетенціям потрібно враховувати сучасні тренди розвитку івент-індустрії. Такі тренди потребують вивчення, аналізу та презентації експертами. Крім того, звертаємо увагу на те, що застосування проектного підходу в організації івенту передбачає наявність трендів на різних етапах підготовки і реалізації івенту. Однак, можна виділити певні тенденції в івент-індустрії з огляду на тренди 2019 рр. [5]:

1. Автентичність івенту - ідея та концепція івенту має відрізнятися оригінальністю, щоб створити незабутній емоційний досвід у відвідувача. 
Наразі ринок івентів тяжіє до так званої «голівудизації» за рахунок використання сторітейлінгу під час формування програмної сітки івенту;

2. Рефлексія відвідувачів - цінність івенту для відвідувача в досвіді, який він може отримати. Відвідувач, перебуваючи в історії, не є суто спостерігачем. Споживач рефлексує з приводу емоцій, які переживає. Ця тенденція характерна не тільки для розважальних чи тематичних подій, а стосується і формату конференцій. Мова йде про використання фасилітованого підходу під час проведення конференцій, де учасники активно взаємодіють між собою;

3. Сталість івент-проекту - організація івенту має передбачати стале використання ресурсів, з метою їх ефективного використання. Наразі в ЄС діє Міжнародний Стандарт ISO 21021 Event Sustainability Management System (2012). Цей Стандарт містить чотири принципи: цілісності (дотримання норм трудового права і законодавства в цілому); інклюзії (забезпечення включення всіх бажаючих до участі в івенті); прозорості (етичність ведення бізнесу і дотримання стандартів); принцип забезпечення охорони навколишнього середовища [6];

4. Використання інструментів сервіс-дизайну під час розробки і планування івенту, вивчення досвіду відвідувача. Слід говорити й про процес персоналізації в маркетингу події за допомогою сучасних технологій;

5. Цифровізація - застосування діджитал-технологій і в роботі над івентом, і під час проведення івенту, і в комунікації з відвідувачами.

Звичайно, необхідно підкреслити, що запропоновані тенденції $\epsilon$ результатом перегляду трендів в країнах ЄС та США. При розробці Стратегії навчання професійним компетенціям слід вивчити ринок івентів в Україні, обговоривши це питання з лідерами ринку.

Вважаємо, що реалізація проекту дуальної освіти в університетах має передбачати розробку Стратегії навчання професійним компетенція. Така Стратегія має на меті залучити різних стейкхолдерів, з метою напрацювання єдиної моделі набуття професійних компетенцій студентами. Стратегія включатиме два блоки питань: яким компетенція навчати і яким чином це роботи. Більше того, розробка такого Документу забезпечить візуалізацію ключових гравців на ринку в тій чи іншій сфері діяльності, її якісне і кількісне наповнення. В перспективі можна буде говорити про формування креативного кластеру, до складу якого будуть входити в тому числі й Університети.

\section{Список використаних джерел:}

1. Про схвалення Концепції підготовки фахівців за дуальною формою здобутmя освіти (2018). Вилучено з https://zakon.rada.gov.ua/laws/main/660-2018-\%D1\%80

2. Петрова І.І. (2019). Професійна підготовка івент-менеджерів у контексті дуальної форми здобуття освіти. Вісник Київського національного університету культури і мистецтв. Серія: Менеджмент соціокультурної діяльності, (1), 2019, 82-104.

3. Future Work Skills 2020 (2019). Вилучено 3: http://www.iftf.org/uploads/media/IFTF_FutureWorkSkillsSummary_01.gif

4. EMBOK Model (2004). Вилучено з http://www.embok.org/index.php/embok-model

5. Event Trends that will Change the Path of Events (2019). Вилучено 3 https://helloendless.com/2019-event-trends/

6. Sustainable Events with ISO $20121 \quad$ (2012). Вилучено 3 https://www.iso.org/files/live/sites/isoorg/files/archive/pdf/en/sustainable_events_iso_2012.pdf 


\section{ВИКОРИСТАННЯ СУЧАСНИХ ІННОВАЦІЙНИХ ТЕХНОЛОГІЙ У ПІДГОТОВЦІ ФАХІВЦІВ 3 ІНФОРМАЦІЙНОЇ, БІБЛІОТЕЧНОЇ TA APXIBHOÏ СПРАВИ}

Ткаченко Дар'я Віталіївна

Державний заклад «Луганський національний університет імені Тараса Шевченка»

Науковий керівник: Курило Н.О.

канд. пед. наук, доцент

Державний заклад «Луганський національний університет імені Тараса Шевченка»

УКРАÏHA

Актуальність статті полягає в тому, що сучасні інноваційні технології широко застосовуються в навчальній діяльності при підготовці майбутніх фахівців у ЗВО.

Метою статті $є$ з'ясування ролі сучасних інноваційних технологій у процесі фахової підготовки студентів з інформаційної, бібліотечної та архівної справи (далі - ІБАС).

Завдання статті полягає в обґрунтуванні необхідності впровадження інноваційних технологій у навчальний процес майбутніх фрахівців з ІБАС.

Сьогодні розширюється процес надання освітніх послуг, збільшується використання сучасних інноваційних технологій у навчальній діяльності студентів. У „Національній стратегії розвитку освіти в Україні на період до 2021 року" наголошується, що інтеграція країни у світовий освітній простір вимагає постійного вдосконалення національної системи освіти, пошуку ефрективних шляхів підвищення ії якості, апробації та впровадження інноваційних педагогічних систем, модернізації змісту освіти й організації ії̈ відповідно до світових тенденцій і вимог ринку праці [4]. Навчання студентів у закладах вищої освіти повинно здійснюватися за новими та високими критеріями, яких вимагають сучасні роботодавці. У першу чергу, це формування висококваліфікованого фахівця, здатного до креативного мислення, до використання інформаційних технологій, оскільки вони сьогодні повинні бути впроваджені в сучасне життя - у будь-якій галузі діяльності.

Серед пріоритетних напрямів державної політики щодо розвитку вищої освіти в контексті євроінтеграції України визначено проблему постійного підвищення якості освіти, модернізацію їі змісту та форм організації навчально-виховного процесу; впровадження освітніх інновацій та інформаційних технологій [1].

Сучасні інноваційні технології є новим викликом часу, зокрема й у системі освіти. Бурхливий розвиток засобів інформатизації (комп'ютерів, комп'ютерних комунікацій, різних електронних пристроїв) породжує нові можливості для застосування інноваційних технологій у навчальному процесі, що робить його більш ефективним та змістовним, а також дає змогу раціонально використовувати навчальний час у ЗВО.

Проблемам упровадження інноваційних технологій у навчальний процес ЗВО присвячено чималу кількість наукових праць вітчизняних та зарубіжних учених. Зокрема, концептуальні засади інноваційних освітніх процесів розглядаються в соціально-філософському контексті цивілізаційних змін, 
обґрунтування нової парадигми освіти, пошуку шляхів подолання ії кризового стану (І. В. Бестужев-Лада, А. А. Герасимчук, В. І. Загвязинський, М.ІІ.Романенко, ін.); використання нових інноваційних технологій та комп'ютерної техніки в освіті (Р. С. Гуревич, А. П. Єршов, М. І. Жалдак, Ю. І. Машбиць, Г. О. Козлакова, О.О.Тесленко, Т. І. Чепрасова); застосування дистанційного навчання (О. О. Андреєв, В. Ю. Биков, В.ІІ. Гриценко, В. М. Монахов, В.В.Олійник, Е. С. Полат та ін.). Проте теоретико-методологічні аспекти впровадження інноваційних технологій у навчально-виховний процес майбутніх фрахівців з інформаційної, бібліотечної та архівної справи ще недостатньо досліджені та потребують подальшого вивчення.

На початку XXI століття в Україні освітній процес зазнав значних реформ. Навчальні заклади XXI століття зумовлюють необхідність докорінного переосмислення освітніх завдань, актуалізації змісту навчання, створення проектно-життєвого простору, технологій становлення індивідуальності студента як суб'єкта й проектувальника життя, спрямованого на розвиток конкурентоспроможної, компетентної особистості, яка творчо підходить до розв'язування проблем, прагне змінити на краще своє життя й життя своєї країни [3].

Навчальні інновації суттєво поліпшують мотивацію студентів до навчального процесу. Сюди належить:

- інтегроване навчання;

- технології групової навчальної діяльності;

- особистісно орієнтоване навчання;

- профрільне навчання;

- інформаційні технології навчання;

- інтерактивні технології ситуативного моделювання та дискусійних питань;

- проектні технології [3].

До основних дидактичних принципів, які повинна задовольняти підготовка фрахівців з інформаційної, бібліотечної та архівної справи в закладах вищої освіти, належать такі [2]:

- принцип гуманізації, який передбачає створення внаслідок упровадження інноваційних технологій оптимальних умов для розвитку кожного студента;

- принцип системності, який означає, що впровадження інноваційних технологій повинно ґрунтуватися на системному аналізі процесу навчання;

- принцип науковості, який передбачає, щоб упровадження інноваційних технологій відбувалося згідно з об'єктивними науковими фактами, поняттями відповідної галузі науки;

- принцип відповідності змісту підготовки майбутніх фрахівців 3 інфрормаційної, бібліотечної та архівної справи сучасному рівню розвитку науки, техніки, технології в усіх сфрерах діяльності, тобто використання інноваційних технологій відповідно до професійних завдань, мети та методів діяльності майбутніх фахівців;

- принцип єдності змісту підготовки та сучасних інноваційних методів, форм і засобів навчання у процесі підготовки майбутніх фахівців з ІБАС;

- принцип доступності засвоєння змісту підготовки фахівців з ІБАС на основі диференціації й індивідуалізації як основних характеристик особистісно орієнтованого навчання; 
- принцип неперервності, наступності й перспективності, який означає, що запровадження інноваційних технологій повинно здійснюватися неперервно протягом усього навчання у ЗВО [2].

На нашу думку, основною перевагою навчання засобами інноваційних технологій фахівців з ІБАС $є$ вміння самостійно працювати з інформацією, гарно орієнтуватися в інформаційному просторі. Процес упровадження інноваційних технологій у навчальну діяльність потребує постійної роботи викладача над удосконаленням дидактичного матеріалу, зокрема програмне забезпечення має містити: завдання та методичні вказівки до практичних та лабораторних робіт; підготовки електронних навчальних матеріалів; розроблені контрольні модульні роботи; доступ до довідкових матеріалів; підсумкові тестові завдання тощо.

Зауважимо, що застосування інноваційних технологій має за мету гуманізувати сучасне освітнє середовище та спонукати студентів до самонавчання та самоосвіти. Вони здатні перетворювати процес навчання в можливість отримання практичних результатів, а саме формування усебічно розвиненої особистості фахівця з інформаційної, бібліотечної та архівної справи. У цьому випадку інноваційні технології постають системою, центральною складовою якої $є$ не лише учасники педагогічного процесу, але й засоби та методи організації навчальної діяльності студентів. Це сприяє ефективності навчальної діяльності, безпосередньому засвоєнню знань та формування вмінь і навичок майбутніх фрахівців з ІБАС.

Вивчаючи переваги й недоліки практичного застосування сучасних інноваційних технологій можна зазначити, що формування знань, умінь і навичок, необхідних фахівцеві з інформаційної, бібліотечної та архівної справи для виконання професійно-посадових обов'язків, сьогодні вже не уявляється без застосування комп'ютерних технологій, а завдання підвищення підготовки фахівців може бути досить успішно вирішуватися за рахунок поєднання раціонального співвідношення між комп'ютерними й традиційними фрормами навчання.

Сучасні Інтернет-технології забезпечують пошук та перегляд у мережі великого обсягу різноманітної інформації у вигляді текстових, графічних, аудіота відеофайлів або програм з будь-якої галузі людської діяльності. Тому майбутні фахівці з інформаційної, бібліотечної та архівної справи повинні оволодіти знаннями, уміннями й навичками, пов'язаними 3 роботою в глобальних інформаційних мережах, зокрема треба вміти користуватися основними сервісами Інтернету, вести пошук необхідної інформації та аналізувати її. Використання світового інформаційного простору розширить можливості особистості для пізнавальної та творчої самореалізації. Найбільш популярними є електронна пошта - засіб обміну повідомленнями, що об'єднує послуги телефону та традиційної пошти; телеконференції - дають змогу брати участь у дискусіях і здійснювати обмін думками; електронні бібліотеки зібрання книг, що зберігаються в електронному вигляді.

Використання засобів інноваційних технологій повинно забезпечувати системність і спрямованість підготовки майбутніх фахівців з ІБАС на вирішення професійних завдань в умовах реформування системи освіти. Необхідно враховувати, що засоби інноваційних технологій, які використовуються в навчально-пізнавальній діяльності, повинні бути адекватними професійнозначущим засобам, а їхнє використання повинно забезпечувати адаптацію тих, кого навчають, до професійного середовища. Такими засобами на практичних 
заняттях може бути застосування методу кейсів, ділових ігор, тренінгів тощо. Однією із сучасних форм навчальної діяльності фахівців $є$ дистанційна освіта, яка дає можливість навчатися на відстані від навчального закладу.

Таким чином, навчально-методична підготовка студентів спеціальності „Інформаційна, бібліотечна та архівна справа” спрямована на формування висококваліфікованого фахівця, здатного в подальшій професійній діяльності вміло застосовувати знання, уміння та навички, набуті у ЗВО. Використання сучасних інноваційних технологій зумовлюється викликами часу, оскільки саме за допомогою їх застосування можна не лише надати ґрунтовні знання студентам, а й навчити самостійно ухвалювати рішення, знаходити необхідну інформацію, розвинути навички аналітичної компетенції. Постійний розвиток сучасних інноваційних технологій та їх застосування в навчальній діяльності, безперервний пошук нових методичних ідей передбачає мотивацію до самонавчання та самовдосконалення майбутніх фахівців з інформаційної, бібліотечної та архівної справи.

\section{Список використаних джерел:}

1. Артюхова, Л. В. (2016). Інноваційна діяльність сучасних закладів культури: досвід, проблеми, перспективи. Проблеми розвитку документально-інфрормаційних систем у сучасному інфоормаційно-комунікаційному середовищі: матеріали Всеукр. наук.-практ. конфф. (м. Рівне, 10 лют. 2016 р.). Рівне: РДГУ.

2. Набока, О.Г.(2010). Принципи впровадження інформаційних технологій у процес фахової підготовки майбутніх економістів. Вісн. Луган.нац. ун-ту імені Тараса Шевченка. Педагогічні науки, 17(204), 175 - 181.

3. Осипчук, О. В. Впровадження інноваційних педагогічних технологій у навчальний процес. Вилучено 3 https://vseosvita.ua/library/vprovadzenna-innovacijnih-pedagogicnih-tehnologij-unavcalnij-proces-35133.html.

4. Про Національну стратегію розвитку освіти в Україні на період до 2021 року (указ Президента України), № 344/2013 від 25.06.2013. Вилучено 3 http://osvita.ua/legislation/other/36322/.

\section{ВПЛИВ ТУРИЗМУ ТА ПРОМИСЛОВОЇ ДІЯЛЬНОСТІ НА ТУРИСТИЧНІ РЕСУРСИ СВІТУ}

Нестерук Марія Ігорівна
здобувач вищої освіти факультету торгівлі, маркетингу та сфери обслуговування
Вінницький торговельно-економічний інститут КНTEУ

Науковий керівник: Малюта Катерина Геннадіївна асистент кафедри туризму та готельно-ресторанної справи

Вінницький торговельно-економічний інститут КНТЕУ УKPAÏHA

В процесі туристської діяльності неминуче відбувається зміна природного довкілля. При цьому негативні зміни переважають, наносячи йому значний $\mathrm{i}$ все зростаючий збиток. Сьогодні абсолютно очевидно, що природа потребує 
захисту від туризму. Багато порушень екологічної рівноваги розпізнаються надто пізно. Виникнення безповоротних процесів в результаті руйнування природного середовища при його неконтрольованому використанні в туристських цілях нерідко призводить до його відмирання. Туристи, короткочасно задовольняючі свої індивідуальні потреби, ставлять їх вище за довготривале використання природних багатств. Під особливо серйозним ризиком знаходяться ті місця перебування туристів, де відсутня необхідна або створена не належним чином інфрраструктура [1]. Поки що вони ще $є$ на карті світу, але усі наведені нижче архітектурні пам'ятники, древні традиції і чудеса природи знаходяться на межі зникнення!

\section{1.Мальдіви.}

Якщо прогнози відносно глобального потепління і підвищення рівня Світового океану виправдаються, Мальдіви зникнуть з лиця Землі одними з перших - їм багато не потрібно. 1192 коралові острови ледве піднімаються над водою: найвища точка архіпелагу - всього 2,4 м. Процес вже пішов, і учені сперечаються лише про те, скільки часу він може зайняти: оптимісти говорять про сотню років, песимісти - про 30. На Мальдівах до цих прогнозів відносяться серйозно і навіть створили фонд по збору коштів на купівлю землі для Нових Мальдів, коли ситуація стане критичною. А кращі тутешні готелі переходять на формат земноводних. Наприклад, в Conrad Maldives Rangali Island в 2005 році відкрили перший у світі підводний ресторан Ithaa Undersea, а у кінці 2018 року - першу резиденцію з підводними кімнатами. Вони находяться на глибині 5 метрів, крізь прозорі стіни видно усе життя коралового рифа - так захоплююче, що і апокаліпсис може пройти непоміченим.

2.Національний парк Глейшер (США).

"Корона континенту" - так називають красивий заповідник на кордоні США і Канади. Тут понад 700 озер, десятки водоспадів і безліч мальовничих стежок для хайкінгу і трекінгу, на яких можна побачити диких лосів, гірських кіз і ведмедів грізлі. На жаль, численні глетчери, що залишилися в горах парку 3 часів льодовикового періоду і дали йому назву, вже давно відступають i ущільнюються загрозливими темпами - колись їх було 150, тепер залишилося $25 \mathrm{i}$, за прогнозами фрахівців, через $10-15$ років може не залишитися жодного.

3.Великий Бар'єрний риф (Австралія).

Великий Бар'єрний риф - найпротяжніша коралова гряда у світі, найбільший на планеті живий організм і об'єкт ЮНЕСКО. Його довжина - майже 2600 км, площа - близько 344400 кв. км, склад - близько 2900 рифрів і 900 острівців. Сьогодні риф майже не захищений від тропічних ураганів, забруднень і особливо знебарвлення, викликаного глобальним потеплінням і підвищенням кислотності води, - через це колонії коралів припиняють ріст, стають крихкими і швидше руйнуються хвилями. Якщо нічого не зміниться, то точка неповернення для рифа настане вже в 2030 році [2].

4.Мертве море (Ізраїль/Иорданія).

Солоне море-озеро знаходиться в найнижчій точці планети (приблизно 430м). Його назвали Мертвим через несумісну з будь-яким життям концентрацію солі, яка може досягати 350 проміле. Але зараз воно дійсно помирає - щороку рівень води опускається приблизно на метр. На берегах утворюються карстові воронки, в які провалюються дороги і цілі будинки. Вода йде насамперед через обміління річки Іордан і ії припливів, перекритих греблями. Багато учених припускають, що остаточно Мертве море не зникне - 
в якийсь момент кількість випаровуваної води співпаде з кількістю вологи, що поступає. Але станеться це не раніше, ніж озеро зменшиться ще як мінімум на третину. I в цьому випадку тутешня крихка екосистема буде безповоротно втрачена - зникнуть пляжі і оазиси, що живляться джерелами на березі.

5.Венеція (Італія).

Вода прославила це місто, і вода ж повільно його вбиває. Немов казковий Кітеж, Венеція йде на дно - приблизно на 5 мм щороку. До повеней тут давно звикли - "аква альта" трапляється всякий раз, коли сильний вітер жене на місто хвилі 3 лагуни, підіймаючи рівень води в каналах. Але затоплення стали частіше і сильніше - учені винять в цьому глобальне потепління. За найпохмурішими прогнозами, вже через 10 років заливати Венецію по самі вуха буде не чотири рази в рік, а двічі в день - з кожним приливом, а до 2100 року від неї залишиться тільки мокре місце. Врятувати місто намагаються за допомогою системи мобільних шлюзів MOSE - роботи над нею велися більше 20 років, але до кінця 2019 року вона повинна нарешті запрацювати. Що, втім, лише відстрочить сумний кінець.

6.Племена долини Омо (Ефіопія).

Низовина долини Омо недаремно входить в список Всесвітньої спадщини ЮНЕСКО. Тут і унікальна природа, і археологічні знахідки, і місцеві племена з їх особливим життєвим устроєм. Найбільш відоме колоритне плем'я мурси, жінки якого прикрашають нижню губу круглими глиняними пластинами. Ймовірно, одвічний спосіб життя мурсів в найближче десятиліття зникне повністю, а колись войовничі і такі несхожі на інших люди одягатимуть свої дивовижні наряди тільки для розваги заїжджих іноземців. Причини - розвиток туризму і наслідок будівництва греблі Gibe III вище за течією річки Омо. Сьогодні займатися сільським господарством стало складно, оскільки річка вже не розливається в колишніх масштабах, а на території, де раніше проходили стада, тепер з'являються національні парки, що захищаються від господарської діяльності [2].

7.Солончак Уюни (Болівія).

10000 кв. км соляних пустель - спадщина далекої екологічної катастрофи (у доісторичні часи тут були озера). Але сьогодні вже і цим надзвичайним місцям загрожує зникнення. Все прозаїчно: виблискуюча соляна кірка приховує під собою колосальні поклади літію. Уряд Болівії покладає серйозні надії на ці родовища, адже їх розробка може перетворити бідну країну Південної Америки на "Саудівську Аравію ери електромобілів". Декілька великих іноземних інвесторів вже зацікавилися розробками, на 2020 рік заплановано будівництво нових масштабних виробництв по видобутку літію. Єдине, що стримує інвесторів, - корупція і страх націоналізації виробництва без пояснених причин. Але якщо уряд Болівії все ж почне грати за правилами, кількість інвестицій неминуче збільшиться, і космічні ландшафти Уюни поступляться місцем куди менш мальовничим індустріальним пейзажам.

8.Сельва Амазонки (Бразилія).

Екваторіальна сельва в Південній Америці - найбільший у світі дощовий ліс, легені нашої планети і рідний будинок як мінімум для 16000 видів дерев i близько $20 \%$ усіх видів птахів. Територія сельви сягає більше 5500000 кв. км. Незважаючи на свої велетенські розміри, басейн Амазонки вже втратив десяту частину лісів з 1960-х років. Ряд дослідників побоюється, що через 15 років зникне ще 30\% від масиву, що залишився, і якщо так піде далі, то через 50 
років від сельви не залишиться і сліду. Всьому провиною вирубування, видобуток корисних копалин (особливо бокситів), пожежі (за період з 1999 по 2010 рік вони знищили 3\% дерев) і усе те ж глобальне потепління, яке викликає тривалі посухи [2].

Можна наводити ще безліч прикладів пагубного впливу туризму, закликаючи і переконуючи з їх допомогою в необхідності дбайливого відношення до природи. Але, як показує практика, мало лише обізнаності населення в необхідності захисту туристичних пам'яток, потрібно діяти, починаючи з себе: цінувати те, що ми маємо і те, що нам подарувала природа, оберігати й раціонально використовувати ці дари, підтримувати їх існування та обов'язково привертати увагу органів влади на нагальні проблеми, щоб пришвидшити їх вирішення.

\section{Список використаних джерел:}

1. Кекушев, В.П., Сергеев, В.П. \& Степаницкий, В.Б. (2016). Основы менеджмента экологического туризма. Київ: Алефа.

2. Васин, І.В. \& Судакова, Д.М. (2019). Ускользающая красота. National Geographic Traveler, (1), 32-43.

\section{ІСТОРІЯ КОНСЕРВАЦІЇ ТА РЕСТАВРАЦІЇ ДОКУМЕНТІВ}

\section{Жданова Лоліта Олександрівна}

магістрант Інституту фрізики, математики та інформаційних технологій Державний заклад «Луганський національний університет імені Тараса Шевченка»

Науковий керівник: Малюк О.Ю. кандидат фрілологічних наук, доцент кафедри документознавства та інфрормаційної діяльності Державний заклад «Луганський національний університет імені Тараса Шевченка» УКРАÏHA

Документи існують з тих пір, як винайдена писемність, тоді ж виникла й проблема збереження фондів. Відомо, що до появи паперу для письма використовували папірус, пальмове листя та інші природні матеріали. У ІІ ст. до н.е. з'явився пергамент. Використовували також дерев'яні дощечки, які скріпляли шкірою. 3 IV ст. Н. е. для сувоїв використовували шовк, у Стародавній Русі застосовувалася береста. На ній писали книги, грамоти. Метал, глина, кора і листя дерев, шкіра і тканина, папір - далеко не повний перелік матеріалів, що застосовувалися для письма, і кожен з них під впливом навколишнього середовища і механічної дії піддавався руйнуванню. Історичні фракти свідчать про те, що хранителі вели не тільки облік, але і робили спроби захистити документи від несприятливих дій природи і людини [1].

Проблема консервації стала більш актуальною 3 винаходом книгодрукування. Із збільшенням кількості книг почали ускладнюватися й завдання їх зберігання. Один із авторів указував, що вологість - найбільш 
небезпечний ворог для книг, і радив зберігати їх тільки на середніх поверхах, застерігаючи від впливу „вологих” західних і південних вітрів [2].

На початку XX ст. зародилася теорія щодо вивчення проблем збереження книг. Визначення терміну консервація запропонував відомий польський реставратор Б. Марконі: „Консервація включає всі заходи і дослідження, метою яких є охорона об'єкта від руйнувань і підтримка його в доброму стані, 3 урахуванням заходів естетичного змісту". У такому формулюванні термін консервація стає близьким до багатьох понять, якими визначаються дії щодо документа. У книгознавстві і бібліотекознавстві під консервацією документів розуміється забезпечення їхнього зберігання за допомогою дотримання відповідного режиму зберігання, стабілізації та реставрації. Консервація (лат. conservatio - збереження) - дії, спрямовані на довгострокове збереження об'єктів [3].

Погляди теоретиків бібліотечної справи змінювалися відповідно до соціально-економічного стану в суспільстві в той або інший історичний період. Важливе значення мають наукові праці Л. Хавкіної. У програму занять перших курсів з бібліотечної справи, які вона відкрила в Москві в 1913 р., входили лекції із „збереження” книжкового майна, включаючи чищення і дезінфекцію книг. Вона написала наукові статі з цієї проблематики, у яких підкреслювала особливу роль і значення запобіжних заходів забезпечення збереження фондів. Першою причиною руйнування книг Л. Хавкіна вважала пил і бруд, тому прибирання і провітрювання приміщень визнавала невід'ємною складовою частиною забезпечення збереження фондів. Вона відзначала, що генеральне прибирання необхідне, щоб видалити пил, який шкідливий як для осіб, які мають справу із книгами, так і для самих книг. „Прибирання представляє радикальний засіб для боротьби з мікроорганізмами, черв'яками і комахами, що винищують книги", - писала Л. Хавкіна. Велике значення вона надавала стану палітурки. Для зберігання видань малого формату нею пропонувалося застосування коробок 3 відкидними кришками. Для попередження руйнування книг слід „лагодити” їх при виявленні хоч би щонайменшої несправності, наприклад, якщо випадає аркуш або відривається корінець палітурки. У періоди епідемій віспи, тифу, дифртерії і інших інфекційних захворювань вважалася необхідною попереджувальна дезінфекція книг, особливе проведення їх дезінфекції при поверненні від хворих читачів. Важливе значення дослідниця додавала й попередженню бібліотечних пожеж. Вона наголошувала: „У книгосховищі повинна бути проведена вода і влаштована значна кількість пожежних рукавів. Корисно також тримати в запасі гасителі, що розвивають вуглекислоту" [4].

Післяреволюційний період характеризувався значним надходженням книг з ліквідованих установ в бібліотеки. У 1918 р. був виданий відомий декрет, відповідно до якого всі бібліотеки і книгосховища були узяті під охорону держави. У 30 -і роки XX ст. прийнято постанову „Про відповідальність за збереження бібліотечного фронду", у якій рішенню завдань фізичного збереження книжкових фондів надається самостійне, важливе значення. Почалася організація спеціалізованих підрозділів, покликаних вирішувати питання збереження книжкових багатств. Ю.Н.Григор'єв підкреслював, що для збереження фондів „необхідне з'ясування, вивчення і усунення всіх тих причин, які викликають передчасну старість книг", і для вирішення цього 
завдання спеціальними знаннями повинні володіти не тільки наукові співробітники, але і бібліотекарі.

У 1927 році заснована Міжнародна Федерація бібліотечних асоціацій ІФЛА. В ії структурі $є$ секція зі збереження та консервації фрондів. Тоді ж була прийнята програма щодо збереження та консервації. Проблемі збереження бібліотечних фондів велику увагу приділяє найавторитетніша в світі організація - Організація Об'єднаних Націй в галузі освіти, науки, культури (ЮНЕСКО). Забезпечення збереження бібліотечних фондів вона розглядає як глобальне завдання всіх цивілізованих країн, світового співтовариства в цілому. ЮНЕСКО разом з ІФЛА розробили документ - „Планування заходів щодо забезпечення готовності до стихійного лиха, природних катастрофр та ліквідації їх наслідків у бібліотеках" [5].

\section{Список використаних джерел:}

1. ГБЛ. (1985). Гигиена и реставрация библиотечных фондов (2-е изд. перераб. и доп.). Москва: Книга.

2. Гриханов, Ю. А. (ред.). (2007). Библиотечная энциклопедия. Москва: Пашков дом.

3. Горбань, Ю. І. (2015). Консервація документів у бібліотеках. Міжнародний вісник: культурологія, фрілологія, музикознавство, 2(5), 37-41.

4. Ванеев, А. Н. \& Минкина, В. В. (2007). Справочник библиотекаря (3-е изд., перераб. и доп.). Спб.: Профессия.

5. Драчук, Р. В. (2016). Збереження фондів у бібліотеках: історичний та сучасний аспект. Бібліотека в освітньому просторі. Інноваційна діяльність в бібліотеках (за матеріалами фахових публікацій): інфрорм. бюл. для працівників бібліотек ВНЗ III-IV рівнів акредитації державної форми власності Хмельницької області № 22. Хмельницький: ХНУ.

\section{СУЧАСНИЙ ОФІС: ТРАДИЦІЇ ТА НОВАТОРСТВО}

Сорокова Аліна Олександрівна

Державний заклад «Луганський національний університет імені Тараса Шевченка»

Науковий керівник: Курило Н.О.

канд. пед. н., доцент

Державний заклад «Луганський національний університет імені Тараса Шевченка»

УКРАÏHA

Актуальність статті зумовлена тим, що розвиток світового суспільства не стоїть на місці, а динамічно розвивається. Кардинальні зміни здійснюються в умовах інтеграції у світовий та європейський простір, де серед організацій та установ виокремлюється сучасний офіс як показник успішної діяльності будьякої організації. Нові технології та стратегії розвитку стосуються сьогодні усіх без винятку сфер життя та людської діяльності.

Мета статmi - з'ясування видів сучасних офісів та організації їх роботи.

Завдання статті - обґрунтування новітньої концепції розуміння сучасного офрісу як комплексного інтегративного поняття. 
Вагомий внесок та значення з дослідження проблем сучасного офісу та організації його роботи в умовах функціонування сучасного суспільства знаходимо у працях М. Виноградського, А. Виноградської, О. Шканової [1], Т. Рибченкової [5], С. Шевчук, В. Скороходова, В. Жуковської [7] та інших науковців.

У перекладі з англійської слово „оffice” трактується як „служба”, „посада”, „відомство” взагалі, зокрема й підприємство, організація, установа; відділ, бюро, департамент управління; контора, канцелярія; службове приміщення, кабінет [6]. Цієї точки зору традиційно дотримувалися тривалий час, розглядаючи офіс лише в одній якості - робочого приміщення.

Сучасний офіс розглядається не тільки як приміщення для роботи, обладнане найновішою організаційною технікою. У першу чергу офіс - це комплексне поєднання багатьох взаємозумовлених чинників: вдале розташування, сучасне обладнання, злагоджена робота колективу як окремої спільноти людей, досвідчене керівництво тощо. Навіть якщо обладнати приміщення офрісу за найсучаснішими вимогами та стандартами, він не запрацює без залучення досвідчених кадрів. На противагу, за умови їх залучення, але не створивши належних умов для роботи, такі працівники протягом незначного проміжку часу залишать це місце роботи в пошуку більш зручних умов. Взаєморозуміння, взаємодопомога, налагодження позитивної психологічної та емоційної атмосфери в офісі $\epsilon$ обов'язковими елементами офрісного менеджменту. Поєднання усіх вищезазначених елементів необхідне для створення моделі „ідеального офісу”. Сучасний ідеальний офіс - це місце з добре налагодженою інфраструктурою, це колектив людей, які розуміють та поважають один одного, де працювати зручно й комфортно. Ми переконані, що ці чинники взаємодоповнюють та поєднують один одного. Якщо один із чинників не враховується, то не буде очікуваного результату.

Що стосується технічного боку розуміння та організації офісу, то для того, щоб іти в ногу з часом, необхідно розвиватися. Сьогодні представники різних організацій середнього та великого бізнесу починають активно застосовувати західні та європейські традиції та методи в організації офрісного простору. За своїм функціональним призначенням офіси складаються з двох частин: фронтodpicy (front office) i бек-офpicy (back office).

Фронт-офіс вміщує кілька зон: зону очікування, приймальню та кабінет керівника, кімнати, у яких здійснюється робота з клієнтами, відвідувачами. У холі офрісу найчастіше знаходиться місце офіс-реєстратора (ресепшн). Зона очікування повинна створювати атмосферу комфорту та зручності, адже перше враження у відвідувачів про фірму створюється саме тут. Тому в холі розташовуються зручні офрісні меблі. До фронт-офісу належать також кімнати, де проходять переговори, презентації та інші заходи. Переговірна кімната комплектується 3 урахуванням функціональності та комфортності: меблі, сучасна презентаційна, проекційна, аудіо- та відеотехніка - усе це повинно сприяти досягненню домовленості й укладанню договорів. Сучасне офісне обладнання дозволяє змінювати функціональність приміщення залежно від потреб фрірми. Традиційно в зоні фронт-офісу розташовуються кабінети вищого керівництва, серед яких кабінет першого керівника без перебільшення можна назвати найважливішою складовою частиною іміджу фрірми. У 
приймальні керівництва розташовується робоче місце секретаря, помічника або рефрерента.

Бек-офріс фрірми являє собою зону, у якій розміщено підрозділи, що забезпечують фінансову, аналітичну, розрахункову, інформаційнодокументаційну й іншу допоміжну роботу. Функціональні й ергономічні меблі, сучасний дизайн інтер'єру, комфортні умови, сучасне інфрормаційно-технічне обладнання - усе це повинно сприяти продуктивній роботі працівників.

Слід зазначити, що офріси сучасних організацій значно відрізняються за рівнем якості й іншими ознаками. Згідно з міжнародними стандартами, до яких наближена і вітчизняна класифікація, офіси розподіляються на три основні класи - A, B, С, до яких додаються офріси вітчизняного стандарту - класи D i E $[7,10-11]$.

Далі ми більш докладно схарактеризуємо офіси, зупинившись на їх класифрікації.

1. До класу „А” належать найпрестижніші приміщення, які розташовані переважно в центрі столиці або великого індустріального міста й мають найвищий рівень архітектурної цінності й офісного сервісу:

- розвинуту й бездоганну інфраструктуру, забезпечення сучасною оргтехнікою, ресепшн, конференц-залами;

- засобами побутового обслуговування та відпочинку, службами безпеки;

-управління й обслуговування, автоматизованими системами життєзабезпечення, підземним місцем для паркування, високим рівнем обслуговування [3].

Доповнення до класності у вигляді „А +” супроводжує будівлі, вік яких не більше трьох років. Офіси в бізнес-центрах класу „А +” характеризуються так званими „розумними” технологіями (централізованим управлінням системами життєзабезпечення, налаштованим мікрокліматом, температурою, вологістю і т. ін.). Обов'язковим $€$ наявність місць для відпочинку й уживання їжі (ресторани, кафетерії), ефеекивне планування та багато світлих приміщень 3 великими вікнами і високими стелями, наявність достатньої кількості місць на стоянці, що охороняється, місткий підземний паркінг, i, що важливо, систем високого ступеня безпеки, професійного управління і високого сервісного обслуговування об'єкта нерухомості [8].

2. Офріси класу „В” відрізняються від попередніх розташуванням у менш престижних районах міста, нижчим рівнем архітектури, оздоблювальних матеріалів, оформлення внутрішнього простору та спектром пропонованих послуг. Наприклад, відсутністю централізованої системи кондиціювання, підземного або закритого паркування тощо. Категорія В являє собою комбіноване планування, що складається з окремих кабінетів і вільного розміщення робочих місць.

3. Офріси класу „C” - це численні, як правило, орендовані приміщення, переобладнані й пристосовані під офріси в будівлях так званих радянських підприємств, що припинили свою діяльність [3].

4. Офісні приміщення класу „D” розташовані в старих будинках, що часто потребують капітального ремонту і мають застарілі інженерні комунікації, відрізняються підвищеною пожежною небезпекою і відсутністю спеціалізованих служб життєзабезпечення. 
5. Клас „Е” - такі офріси розташовані в підвальних або напівпідвальних приміщеннях, переобладнаних квартирах у старому житловому фонді, у непристосованих старих будівлях, які потребують реконструкції [Там само].

Традиційний офіс припускав використання переважно паперових носіїв інформації. Тиражування документів здійснювалося за допомогою звичайної друкарської машинки або традиційної малопродуктивної копіювальної техніки (ротатор, ротапринт тощо). Інфрормація передавалась із застосуванням звичайного телефону, поштою або кур'єрським розсиланням. В умовах традиційного офісу підготовка й оформлення документів являла собою трудомісткий малопродуктивний процес за допомогою таких традиційних засобів як леза для скобління тексту, коректувальні стрічки, копіювальний папір тощо. Перевірка, виправлення й нескінченні передруки документів значною мірою сповільнювали процес документообігу, роблячи його неефективним. Поява на ринку персональних комп'ютерів та іншої офрісної техніки докорінно змінили уявлення про організацію офісної роботи.

Сучасний офіс цілком можна назвати електронним, тому що процес створення, обробки й систематизація документів; обмін інформацією 3 клієнтами й колегами - усе це здійснюється із застосуванням електронного встаткування й програмного забезпечення. Концепція електронного офрісу надає великі перспективи для суттєвого підвищення ефективності діяльності офрісних працівників. Зокрема, електронний офіс дозволяє:

- відмовитися від внутрішньоофісної документації на паперовій основі;

- удосконалити розподіл функцій у процесі інформаційного обслуговування керівництва;

- відновити традиційну форму концентрації офісної діяльності навколо фахівців у галузі ДЗУ або керівника.

Спільний розвиток та поступове об'єднання обчислювальної та комунікативної техніки забезпечує офісним працівникам необмежений доступ до будь-якої потрібної інформації та користування обчислювальними потужностями, незалежно від місцезнаходження того, хто працює в офісі [2].

Вважаємо, що в сучасних умовах створення та адміністрування офісів повинно базуватися на принципі діалектичного поєднання „зовнішніх" та „внутрішніх” аспектів. Тобто потрібно зосереджуватися як на технічному, функціональному оформленні офрісного приміщення, так і на формуванні позитивної психологічної та емоційної атмосфери всередині робочого колективу. Для цього особливу увагу треба надавати питанню підбору кадрів, створенню та впровадженню корпоративних цілей, організації заходів підвищення кваліфікації та проведенню позаробочих корпоративних заходів.

3 іншого боку, розглядаючи офріс як інтегроване поняття, не можна не надавати уваги питанню створення професійного колективу, який становить вагоме значення для функціонування сучасного офрісу. Важливим $\epsilon$ удосконалення системи постійного підвищення кваліфікації працівників шляхом навчання, перепідготовки, розвитку ініціативи, творчості, запровадження новітніх методів роботи з персоналом, таких як коучинг $\mathrm{i}$ стретчинг. Для формування злагодженого та професійного колективу потрібно розробляти системи підбору, навчання, оцінки та переміщення керівних кадрів, планування кар'єри. Потрібно пам'ятати також про застосування стилю 
керівництва, адекватного внутрішнім і зовнішнім чинникам, що впливають на організацію. Застосування найбільш ефективних методів підбору персоналу, його оцінки, формування працездатного, психологічно сумісного складу працівників, максимально сприятливого соціально-психологічного клімату вже досить значний час $€$ головною складовою офісного менеджменту в розвинутих країнах, таких як США, Велика Британія, Франція, Німеччина, Японія тощо. Також у зазначених країнах великої уваги надають формуванню відкритої корпоративної культури організації, розробка спільних цінностей, визнаних і схвалених співробітниками, підвищення особистої ефрективності працівників.

У вітчизняній бізнес-культурі подібна практика тільки починає впроваджуватися, проте можна дійти висновку, що наразі все більшої популярності набуває розуміння офісу як комплексного поняття, що об'єднує багато чинників, 3 одного боку - місце розташування, приміщення, організаційне та технічне забезпечення, інфрраструктура, з іншого - колектив, наявність професійних кадрів, психологічна та емоційна стабільність, наявність системи підбору кадрів та можливостей для підвищення профресійного рівня працівників. Це є цілком виправданим, оскільки Україна переймає передовий досвід розвинутих країн та перебуває під впливом процесів глобалізації світу в різних аспектах суспільного життя - культурному, освітньому, інформаційному тощо.

Таким чином, сучасний офріс - це не просто приміщення, у якому розташовані кабінети керівництва, спеціалістів і служб. Це складна система, що залежить від грамотної організації роботи в ньому, інфрраструктура, яка забезпечує ефективне фрункціонування усієї компанії. Звичайно, ми не відмовляємося від усього традиційного, ми беремо найкраще з нього, зокрема досвід, додаємо технології та стратегії управління, залучаємо висококваліфікованих фрахівців, і отримуємо сучасну концепцію офрісу. Сьогодні для цього $є$ багато можливостей не лише з технічного боку, а й з боку підготовки досвідчених кадрів для роботи в офрісах.

\section{Список використаних джерел:}

1. Виноградський, М. Д., Виноградська, А. М. \& Шканова, О.М.(2002). Організація праці менеджера. Київ: Кондор.

2. Електронний офріс. Вилучено з https://studopedia.su/8_13930_tema-elektronniy-ofis.html.

3. Концепція сучасного орбісу: від традицій до нових технологій. Вилучено 3 https://studfiles.net/preview/6022399/.

4. Посада "Офріс-адміністратор" у Класифікаторі профресій. Вилучено 3 : https://www.kadrovik01.com.ua/article/3905-posada-ofs-admnstrator-u-klasifkator-profesy.

5. Рыбченкова, Т. В. (2007). Рациональная организация офисного пространства. Секретарьрефрерент, (5), $92-95$.

6. Сутність ma види оррісів.

Вилучено 3 http://referatwork.ru/lectionbase/psihologiya/219650_sut.

7. Шевчук, С. П., Скороходов, В. А. \& Жуковська В. М. (2010). Управління сучасним офбісом (офріс-менеджмент). Київ : Вид. дім „Професіонал”, ЦУУЛ.

8. Яворина, А.Н. Класифрікація осрісних приміщень. Вилучено 3 http://www.yavoryna.te.ua/index.php?option=com_content\&view=article\&id=835:2012-10-31-0813-43\&catid=1:company-news\&ltemid=115. 


\section{СУЧАСНІ ПІДХОДИ ДО СТВОРЕННЯ КОМФОРТУ У ЗАСОБАХ РОЗМІЩЕННЯ}

Нестерук Марія Ігорівна

здобувач вищої освіти фракультету торгівлі, маркетингу та сфери обслуговування

Вінницький торговельно-економічний інститут КНТЕУ

Науковий керівник: Іваніщева Ольга Анатоліївна старший викладач кафедри туризму та готельно-ресторанної справи

Вінницький торговельно-економічний інститут КНТЕУ

УKPAÏHA

Останнім часом в наукових публікаціях найбільше акцентується увага на особистісному аспекті якості обслуговування, що включає професіоналізм персоналу, культуру поведінки, етику. Гостинність як добрі особисті стосунки персоналу до клієнтів виходить на перший план. Проте, сучасна людина пред'являє всезростаючі вимоги і до матеріального забезпечення місця перебування, тому речові елементи комфорту також грають важливу роль в залученні клієнтів. Саме технічне оснащення готелю, склад і якість номерного фонду, набір послуг, що надаються, лежать в основі класифрікації готелів по рівню комфорту у більшості країн. Таким чином, створення комфортного матеріального місця перебування туристів $€$ першим кроком на шляху досягнення успіху в готельному бізнесі.

Важливою фрункцією оснащення $€$ забезпечення комфорту. Одним 3 основоположників концепції «комфорту в готелі» по праву вважається швейцарський учений-практик Жак Леві. Він запропонував чотирьохкомпонентну концепцію комфорту (температурний комфорт, якість повітря, технічний і економічний комфорт), де акцент робиться саме на матеріальних складових комфорту [1].

Продуманий дизайн інтер'єру і атмосфера затишку - дві основні умови комфорту в місці тимчасового перебування. «Начинка» готельного номера питання бюджету, стилю і добросовісного відношення до постояльців [2].

В першу чергу, про технічне оснащення готелю гостей інформує меблювання їх номера. У готелях, які піклуються про комфортабельний відпочинок своїх клієнтів, меблі повинні відповідати декільком основним вимогам: зручність, функцціональність, естетичність, екологічність і безпека. У меблювання номера в обов'язковому порядку входить: просторе спальне місце (залежно від номера 1 - або 2-місне), шафа для одягу і ручної поклажі, крісла або м'які стільці та письмовий столик [3].

Величезну роль в технічному оснащенні грають інноваційні інженерні рішення, які використовуються при модернізації наступних комунікаційних систем:

-вентиляція. Готелі щодня відвідує безліч людей, тому усі приміщення необхідно ретельно провітрювати. Постійний приплив свіжого повітря можна забезпечити за рахунок природної або штучної вентиляції. Такі системи можуть відрізнятися між собою по загальній організації переміщення повітря, а також по своєму безпосередньому призначенню (вони бувають витяжними 
або, навпаки, припливними). Іноді при проектуванні вентиляції власники готелю акцентують увагу також і на технології очищення повітря, яка надалі допомагає мінімізувати потрапляння в приміщення алергенів і яких-небудь небезпечних бактерій.

-Водопровід. Хороший тиск води в трубах - це одна з головних вимог, що пред'являються до місць розміщення. Окрім нормального функціонування систем подання води і каналізації, це дозволяє забезпечити пожежне водопостачання і як наслідок підвищити рівень безпеки для своїх постояльців.

-Опалювання. Залежно від переваг власників готелю і деяких супутніх нюансів воно може бути паровим, повітряним або водним. Втім, це, як правило, відноситься до усієї будівлі готелю - для опалювання номерного фонду все ж краще використати індивідуальні системи.

-Електрика. Оскільки в готелях в різних цілях використовується велика кількість електроенергії, доцільно застосовувати додаткові трансформатори, відсікачі і інші пристрої для підтримки нормальної напруги в мережі і мінімізації відключення усього комплексу від електрики [3].

Технологічне оснащення. Для того, щоб йти в ногу з часом і надавати своїм клієнтам дійсно якісні послуги, готелі просто зобов'язані занепокоїтися технологічним оснащенням номерного фонду. Воно включає: устаткування номера якісними телевізійними системами, надання технології Wi-Fi на усій території комплексу, установку систем кондиціонування повітря, розробку своїх власних технологічних проектів, що спрощують життя постояльцям (наприклад, в одному з готелів Лондона було вирішено замінити стандартну табличку на дверях «Не турбувати» на електронне табло, яким гість готелю, не покидаючи ліжка, може управляти за допомогою пульта) [3].

На сучасному етапі розвитку суспільства готель виходить далеко за рамки класичного визначення «місце для нічлігу». Вимоги до комфорту проживання в готелі постійно зростають, і від здатності задовольнити їх залежить конкурентоспроможність готелю на ринку готельних послуг. Тому при оснащенні готелю надзвичайно важливо задовольнити потреби гостя усім можливим устаткуванням задля забезпечення комфортного та зручного перебування.

\section{Список використаних джерел:}

1. Черникова, В.И. (2009). Современный подход к определению «комфорта в гостинице». Економика, организация и управление предприятиями туристической индустрии и туристической сфреры в иелом, (12), 232-237.

2. Оснащение номера. Основные задачи. (2017). Вилучено 3 https://www.frontdesk.ru/article/osnashchenie-nomera-osnovnye-zadachi.

3. Техническое оснащение гостиницы. (2016). Вилучено з https://www.reginahotels.ru/dopolnitelno/interesnoe/tehnicheskoe_osnaschenie_gostinitsyi/. 


\section{SECTION XI. SCIENCES PEDAGOGIQUES}

\section{DOI 10.36074/29.11.2019.v4.09 \\ DEVELOPMENT OF FUTURE ENGINEERS' PROFESSIONAL COMMUNICATIVE COMPETENCE AT ESP CLASSES}

RESEARCH GROUP:

Tetiana Goncharenko candidate of pedagogical sciences, the head of foreign languages department National Technical University "Kharkiv Politechnic Institute»

Lidia Dyomochka

assistant professor, foreign languages department National Technical University "Kharkiv Politechnic Institute»

Maryna Durnyeva

senior teacher, foreign languages department National Technical University «Kharkiv Politechnic Institue»

UKRAINE

The study of pedagogical conditions of professional training of future software engineers at a technical university has proved that the most important for the it is the integration of the content of mathematical, foreign language, social and humanitarian, professional training of future software engineers; encouraging students to acquire knowledge, skills and abilities, and developing personal qualities which are important for the professional activity of a software engineer; the use of a dual approach aimed at improving the quality of training of future software engineers based on the university's cooperation with IT companies. The efficiency of these conditions was experimentally tested and confirmed [1]. After the experiment, the biggest changes occurred in the students' level of the ability to develop software product and the ability to test software product. The students' level of communication skills has changed the least and, as the research showed, their development may require additional efforts.

In order to determine the positive or negative students' assessments regarding their professional training in higher education, a questionnaire was conducted among the students of "Software Engineering" direction at NTU "KhPl". The survey was conducted among the students of the 5th-6th years of study, obtaining the Master's degree and having experience in the chosen specialty. And if $71 \%$ of students were satisfied with the quality of professional training in the chosen specialty, none of the respondents thought that it should be changed radically. But at the same time, students realize the lack of some aspects in professional training. Namely, a large number of students surveyed (63\%) believe that it is very important for them to develop professional communication skills at the university, which would greatly improve their integration into the professional environment.

The analysis of the curricula and syllabi of the departments which prepare future software engineers showed that they do not provide courses that are directly 
focused on the development of professional communicative competence. The role of foreign language for special purposes is often underestimated, but the integration of English content for special academic purposes (ESAP) and professional training, which involves not only professional learning of English, but also the use of language as a means of developing professional knowledge, skills, abilities, qualities, values of students, can be the solution to this problem [2].

The need for foreign language proficiency in any field of study is beyond doubt, especially when it comes to programmers. But how can a foreign language be transformed into an integral part of a person's professional competence from the category of a general human culture?

From 2014 to 2019, the Department of Foreign Languages of NTU "KPI" took an active part in the project "English for Universities". Due to the participation in the project, there have been dramatic changes in the teaching of English. The new curricula and syllabi have been changed so that they are now based on the communicative needs of the modern engineer; in particular, the Bachelor's course in English (1st-2nd years of study, 124 academic hours) was modified in accordance with the professional needs of future specialists, which were reflected in the following modules:

1) Communication in an academic and professional environment;

2) Information search and analysis;

3) Information presentation;

4) Employment procedure.

It is obligatory to plan and adjust the content of the classes and the way of learning the language, taking into account students' opinions. Online students surveys are periodically carried out to assess their achievements and to express language learning preferences. In addition, there is a detailed analysis of curricula of various specialties regarding students' needs to acquire the necessary professional competences (PCs) and demonstration of their learning outcomes (LOs). That means that so-called needs analysis of both students and institutions of higher education is conducted.

The analysis of the curriculum for "Software Engineering" showed that professional competencies which could be directly developed by future software engineers during a foreign language course are PC-1 (the ability to analyze subject areas (domains), formulate requirements, identify, classify and describe the tasks, find methods and approaches to solve them); PC-4 (the ability to apply and develop fundamental and interdisciplinary knowledge to successfully solve software engineering tasks); PC-1 (the ability to formulate and meet the requirements); PC5 (the ability to prepare and present software documentation and manuals).

Besides, the analysis of curriculum learning outcomes revealed that those directly related to ESP learning are LO -1 (the ability to know and have language skills, ability to communicate in a professional-level dialogue with colleagues and subject matter experts); LO-2 (the ability to demonstrate processes and results of professional activity, developing presentations, reports); LO-1 (the ability to use information and communication technologies in communication, exchange, collection, analysis, processing the information); LO-3 (the ability to understand, analyze, purposefully seek and select the necessary information resources and knowledge essential for solving professional tasks, taking into account modern achievements of science and technology); LO-6 (the ability to have skills for 
participating in team development, coordination, design and release of all types of program documentation).

Based on the results of the analysis, each of the above mentioned competencies and learning outcomes has been considered within one of four modules during which these competencies may be acquired. Thus, PC-1 is mainly developed when studying Module 2 "Information Search and Processing", where almost all types of learning speech activity are focused precisely on the ability to analyze, compare, find causality and describe them through appropriate language tools and structures; PC-4 demonstrates the ability of a future software engineer to use foreign language (which is the material of all four modules) to successfully solve software engineering tasks; PC-1 is the ability to formulate and provide requirements i.e. the ability to formulate an opinion and formulate it in the form of instructions and requirements, or as a description; PC-5 is the ability to prepare and present software documentation and manuals.

The first and more general LO-1 is accumulated through all four modules, in the form of teaching monologic and dialogic speech, namely in the presentation of themselves as a specialist, dialogic speech in the simulation of skirmish situations, while modeling speech situations related to travel and business trips (Module 1), while verbally commenting on visual means of reflecting processes and trends (Module 2), while presenting the results of the chosen research topic and answering questions (Module 3), while analyzing Soft and Hard skills required for work in the chosen specialty, modeling situations with an employer and interviews at the selected vacancy (Module 4).

The result of training LO-2 is achieved during Module 3, when students are taught the art of presenting the results of their work. With regard to reading professional-oriented literature, this type of teaching is done in order to understand the basic ideas, to find the necessary information, to determine the purpose of the publication. Full text translation is excluded from the language learning tasks in the new program. In order to acquire skills that directly demonstrate LO-3 and LO-1 skills, within Module 2 "Search and processing of information" students are taught such types of reading as scanning and skimming, which is an integral part of the professional future of a student of any profession, and especially of future software engineers, also they learn to critically analyze the readings, make reports, describe any graphical information, such as charts, tables, graphs.

To provide students with the maximum opportunity to practice using language in the classroom, such teaching methods as pair work and group work, brainstorming, project work, etc. are used. The grammatical aspects are covered as needed, not as a separate part of the lessons. Mostly, authentic text materials and textbooks are used in classes and for independent work. Listening is an integral part of every class.

All these provisions are basic for training future specialists in any engineering specialty, including the specificity of each of them. The program was designed in such a way that the priority task in teaching English was the formation of professional competencies aimed at the practical use of English as a tool for the realization of professional interests.

References:

1. Goncharenko, T.Ye. (2018). Pedagogical Conditions of Future Engineer Programmers' Professional Training in a Technical University (authoref. dis...candidate of ped. sciences). H.Skovoroda Kharkiv National Pedagogical University. Kharkiv, Ukraine. 
2. Lazareva, O. \& Kovtun, O. (2017). Developing soft skills at ESP classes in technical HEls. Psychological and pedagogical problems of modern specialist formation. Warsaw: ANAGRAM; Kharkiv: KRPOCH.

\title{
DIGITALIZATION AS INEVITABLE VECTOR OF THE EDUCATIONAL SYSTEM DEVELOPMENT IN GERMANY
}

\author{
Alina Dzhurylo \\ $\mathrm{PhD}$, Senior Researcher of Comparative Education Department \\ Institute of Pedagogy, National Academy of Educational Sciences of Ukraine
}

UKRAINE

The implantation of modern digital technologies requires a completely new rethinking of the functioning and vectors of the development of school education, because until now our ideas about education have been based on the norms and values of the twentieth century. In this way, teachers are continuing to prepare students for the tasks of the past, rather than for the new changing challenges of the present and future.

Digitization is fundamentally changing our existence at all levels - everyday life, professional level, educational grounding. Just one glance at the unrestrained development of artificial intelligence makes it clear what awaits us in the near future. It is estimated that in the next 20 years, more than fifty professions (logisticians, notaries, realtors, secretaries, analysts, etc.) will disappear, and more than 200 new ones will appear, of which we have no idea yet. Educators are already facing the challenge of defining educational goals for children who were born after 2015. In 23 years, the modern Digital Generation will be replaced by next-generation which is called Children of Smartphones, Google Babies, Generation Zen or Generation Alpha.

Industry 4.0 has had a significant impact on the educational environment, making blockchain technology, artificial intelligence, cloud technology, the Internet of Things, and gamification an integral part of the modern educational process.

In Germany, policy makers are increasingly focusing on digital skills every year. In $2017,68 \%$ of reported Germans answered that they had at least basic digital skills (these results were equal to the results of the previous year's inquest), ranking Germany seventh among EU Member States (EU average of 57\%) [1]. In the European Commission Report Volume 2 of the Education and Training Monitor 2018 (Germany) it is noted that the political attention to digitalisation, including infrastructure and skills, is high, with a newly established post of state minister for digitisation. For schools, the DigitalPakt Schule, announced in 2016, was endorsed by the new government. It stipulates that the federal government will invest EUR 5 billion in digital infrastructure in schools within the next 5 years. The federal states will in return provide necessary teacher training and curricula updates [2].

Various federal states initiatives are aimed at enhancing the sustainable professional development of teachers' digital skills, which surveyed teachers found to be inadequate according to a digital education survey. Both German teachers 
and students evaluate media competency, including data protection and ethics, extremely important [2].

While media competence is a policy priority, shortcomings and big regional differences appear to exist with regard to news and the ability to analyse and contextualise them, which might compromise effective education on fake news at schools. The survey of a small sample which was conducted by the Technical University of Dresden [3] showed that usage of online and social media for news consumption is hardly present in curricula, and that news literacy forms a minimal part of initial teacher training, resulting in a lack of basic skills and knowledge on the subject.

We should understand that radical transformational processes in the field of education are taking place not only in Germany, but also in the leading countries of the world, as so as in Ukraine. In the Paris Communiqué [4], which was adopted on May 25, 2018 at a conference by the Ministers responsible for higher education on European continent, it is emphasized that, over the last 20 years, improving the quality of education and its relevance to social needs have been a cornerstone of both the Bologna process and other structural reforms in the field. In the future, in the opinion of the authors of the communique, it is important to focus on cooperation in the introduction of innovative teaching and learning practices, their support, stimulation and dissemination.

Student-centered learning and open education in the context of lifelong learning is considered in this paper as a kind of mainstream of contemporary academic policy. Particular attention is paid to digital and blended learning, as well as the digitalisation of the educational process as such. Indeed, nowadays, the innovative learning process essentially requires innovative means and methods of its implementation. It is unlikely that the traditional chalk and blackboard in our classes would be able to open a window to the world of the computerized and digital future for new generation.

\section{References:}

1. European Commission, Digital Economy and Society Index 2018, Country Report Germany. (2018) Retrieved from http://ec.europa.eu/information_society/newsroom/image/document/201820/dedesi2018-country-profile_eng_B43F6D80-F854-82CB-6BF70068ACC73D74_52214.pdf

2. European Commission, Education and Training Monitor 2018 Germany. (2018).

3. Retrieved from https://ec.europa.eu/education/sites/education/files/document-library-docs/etmonitor-report-2018-germany_en.pdf

4. Hagen, Lutz, Renatus, Rebecca \& Obermüller, Anna. (2017). Nachrichtenkompetenz durch die Schule eine Untersuchung im Auftrag der Stiftervereinigung der Presse. Retrieved from https://tudresden.de/gsw/phil/ifk/ressourcen/dateien/news/2017/PK

5. EHEA Ministerial Conference. Paris Communiqué. (2018). Retrieved from http://www.ehea.info/media.ehea.info/file/2018_Paris/77/1/EHEAParis2018_Communique_final_ 952771.pdf 


\title{
IMPLEMENTING BLENDED LEARNING FOR STUDENT SUCCESS
}

\author{
Alina Kruk \\ Candidate of Philological Sciences, Senior Lecturer \\ Kamianets-Podilskyi National Ivan Ohiienko University
}

UKRAINE

Every year blended learning approach is becoming more popular among the teaching staff. There are many different ways to learn effectively. Blended learning is a combination of online capabilities and classic approaches to learning process. With the development of modern information technologies, different techniques become more commonly used in the process of learning ESP. Blended learning technologies based on online and offline schemes were investigated by C. Latchem, G. Motteram, J. Richards, K. Thorne, B. Tomlinson, C. Whittaker and other scientists.

There are several blended learning models. They are rotational, virtual, selfblend, and, of course, flex-model. Colin Latchem notes that "flexible learning places the learners in primary control" [1]. The author proves that "it offers them choices in the where, when, how, for how long and by what means of study, according to their needs and circumstances" [1]. Students can study with the help of face-to-face, fulltime, part-time, accelerated and decelerated means.

Blended learning includes the following: thematic courses, testing, project method, specialized portals, communication sites, video tutorials, webinars, video conferences, audio podcasts, mobile applications, and of course, Moodle as online learning space. Moodle is important in learning ESP. Brian Tomlinson and Claire Whittaker note that in order to reach relevant objectives, "a Moodle platform was set up where participants could read articles on assessment, watch videos of experts talking about different areas of assessment and testing, and link to a variety of other related websites" [4]. In this case, students are given the opportunity to perform group and paired communication tasks, where the teacher only acts as a facilitator.

In blended learning it is important to attract Internet technologies, namely online games, courses and mobile applications. Thus, Gary Motteram indicates that "technology continues to be used for all sorts of specific language learning activities, such as oral practice and reading and writing skills development" [2]. Online tools are useful in blended learning process. Due to the use of online format, students can control their time, place, regularity and format of mastering the material, ie they can work independently and responsibly.

The diversity of learning allows teacher to see gaps in students' knowledge and to analyze their progress better. Improving motivation and application of various techniques stimulates information absorption that is desirable for students. Communicative language, jigsaw activities, pair and group work are also very important in blended learning. Depicting information-gap activities, Jack Richards tells that "more authentic communication is likely to occur in the classroom if students go beyond practice of language forms for their own sake and use their linguistic and communicative resources in order to obtain information" [3]. As follows 
they will be able to draw appropriate vocabulary, grammar, and communication strategies to complete corresponding tasks.

Thereby, blended learning is one of the most relevant educational technologies to date. There are many benefits of distance and traditional learning. Blended learning develops a sense of self-confidence, enhances emotional intelligence and personal motivation, personalizes the learning process through the attraction of technology.

\title{
References:
}

1. Latchem, C. (2017). Using ICTs and Blended Learning in Transforming TVET. Burnaby: UNESCO and Commonwealth of Learning (COL).

2. Motteram, G. (2013). Innovations in learning technologies for English language teaching. London: British Council.

3. Richards, J.C. (2006). Communicative Language Teaching Today. New York: Cambridge University Press.

4. Tomlinson, B. \& Whittaker, C. (2013). Blended Learning in English Language Teaching: Course Design and Implementation. London: British Council.

\section{INNOVATIONS IN THE FIELD OF FOREIGN LANGUAGES TEACHING}

\author{
Nataliia Sarnovska \\ Senior Lecturer \\ Kyiv National University of Culture and Arts \\ UKRAINE
}

\begin{abstract}
Presently, due to the trend of globalization and the close interaction of different languages and cultures, a foreign language is acquiring special significance, because often many people need to communicate or conduct any activity in a foreign language. Therefore, the need for learning a foreign language is growing and there is growing interest in how to teach this subject. According to the question applying of new approaches and techniques in the field of teaching foreign languages arose. Along with traditional methods, so-called innovative techniques arise when teaching a foreign language. This is due to the fact that the world is in constant change, cultural experience is being integrated, and the problem of adapting to new conditions by expanding one's own knowledge of the languages being studied and their carriers becomes especially urgent. If we look directly to the teaching of foreign languages, then here the use of new technologies is becoming increasingly relevant.

In general, innovations, or novelties, are applicable in the field of teaching, including a foreign language, since it is impossible to ignore the innovative component, which serves as an excellent aid to the teacher. As you know, the Ukrainian educational system implies the so-called principle of variability, which makes it possible for the teacher to focus on multiple methods, including copyright
\end{abstract}


ones. The teacher was given great freedom of action, which includes freedom of choice of various innovative technologies, thanks to which the development of the entire educational process is underway.

In connection with the expansion of the communications network, the advent of the Internet, the informatization and computerization of society, the teaching of a foreign language with the use of computer technology in foreign language lessons is of particular importance. In this technique, two components can be distinguished. Firstly, computer programs created in various forms and for different levels of teaching a foreign language. Secondly, the use of Internet resources, which can serve not only as an indispensable source of information, but also "are an excellent means of interactive communication between different language groups" [2]. They also allow you to participate in the "development of international projects, conducting research" [4]. This method allows to create special training programs for working individually or in groups, in addition, it can be either training exercises, tasks for modifications and permutations in the text, as well as exciting game programs. On the one hand, this method has many positive characteristics: computer technology attracts students, helps increase the motivation for learning activities, and develop additional skills, along with language learning. On the other hand, the main disadvantage of this technology is that "computer technology is not intended to form communicative competence" [3], which is one of the key components of the process of a foreign language teaching.

Continuing the question of the communicative competence developing importance in foreign languages teaching, we note the "communicative task method" [5] highlighted by the authors and considered innovative, the main principle of which is in students performing various forms and using varied types of interaction to solve communicative tasks. Thus, due to the presence of a problematic issue, a search is made for its solution and in the search process, an analogue of the situation of real interaction is developed in which communication takes place in a foreign language. This innovative technique is very effective, since students are directly forming foreign communicative competence.

Another technology is the technology of multilevel (differentiated) training or the technology of individualization of training, in the framework of which a personalityoriented approach is directly implemented, individual characteristics, capabilities and needs of students are taken into account. Thus, the focus is on the characteristics of each student individually, which allows them to reveal their potential and contributes to the more successful formation of a "multicultural linguistic personality capable of communicating with native speakers of other cultures" [4].

Based on the fact that innovation depends on people and is created by people, one can determine yet another way of innovative development in the field of education in general and in the field of teaching foreign languages. This approach consists in focusing on the development of the teacher's potential, since the personality of the teacher, which, on the one hand, is already formed, but, on the other hand, has unlimited opportunities for self-development and improvement, is of key importance in teaching a foreign language.

This implies the need for constant and continuous education of the teacher in the process of his pedagogical activity, the creation and implementation of new 
technologies, creative approaches to educational activities. Accordingly, the position of the teacher is changing - "the teacher becomes an accomplice in the research, creative cognitive process, mentor, consultant, organizer of students' independent activities" [5].

In conclusion, it is worth noting that many new technologies are currently being applied to improve the results of students learning a foreign language. All areas of innovative development that are now being implemented are part of a single whole and, in their integrated application, contribute to the successful development of a foreign language by students and the formation of foreign language communicative competence.

\title{
References:
}

1. Anburaj, G., Christopher, G., Ming \& Ms. Ni. (2014). Innovative Methods of Teaching English Language. Journal Of Humanities And Social Science (IOSR-JHSS), (19),8)), 62-65. Retrived from http://www.iosrjournals.org/iosr-jhss/papers/Vol19-issue8/Version4/M019846265.pdf [in English]

2. Dzhumanova, L. S. (2004). Innovatsionnyie tehnologiyi I obucheniye inostrannym yazykam [Innovative technologies and foreign languages teaching]. Molodoy uchyenyiy, (19), 523 - 525. [in Russian]

3. Kashina, Ye. G. (2006). Traditsii i innovatsii v metodoke prepodavaniya inositannogo yazyka. [Traditions and innovations in the methodology of a foreign language teaching]. Retrived from http://media.samsu.ru/files/3/253_\%C7\%E0\%EA\%E0\%E7\%20422.pdf [in Russian]

4. Kotunova, M. N. (2012). Sovryemennyye tehnologii obucheniya inostrannomu yazyku [Modern technologies of foreign languages teaching]. Retrived from http://deutschbalakovo.ucoz.ru/publ/nauchno_issledovatelskaja_dejatelnost/sovremennye_tekh nologii_obuchenija_inostrannomu_jazyku/3-1-0-2 [in Russian]

5. Palagutina, M. A. (2011). Innovatsionnyue tehnologii obucheniya inostrannym yazykam. Problyemy I perspectivy razvitiya obrazovaniya. [Innovative technologies of teaching foreign languages. Problems and prospects for the development of education]: proceedings of international scientific conference. Perm, Russia: Merkuriy, (1) [in Russian]

\section{INTERACTIVE ENGLISH LANGUAGE TEACHING}

\author{
Natalia Nikitina \\ National Technical University of Ukraine \\ "lgor Sikorsky Kyiv Polytechnic Institute»
}

UKRAINE

Learning is associated with boring sitting with a book or listening to monotonous teacher's monologue about Present Simple or Gerund formation. Today language teaching is becoming more and more active - teachers prepare different types of activity to give the information in more effective way.

While studying student can be the passive element of teaching process (he only listens to the teacher and probably obtain some knowledge), on the other hand, he 
can take active part in this process (the classical example is answering the teacher's question according to book's paragraph). But the most interesting is interactive type. Peculiarity lies in the interaction not only between teacher and student, but between students as well.

Interactive teaching gives wider opportunities to apply obtained theoretical or practical knowledge in more convenient way. Interactive teaching means immediate use of new lexicology, terms, rules in more or less real situations. Teacher in this type of activity is a sculptor who is modeling different situations to practice new material. This type of teaching is mostly suitable for children teaching due to the fact that they perceive information practically. Anyway, child or adult will learn more effective if the information is presenting in unusual way.

Students like such kind of teaching firstly because it is unusual, secondly, it give an opportunity to express yourself, thirdly, all students take part in this activity. Modest and shy students will also take part in such activities if teacher organize everything correctly. All students in the class cannot have the same language level (it is a teacher dream to work in the class where all students know English perfect:). Hence, in some minutes some students are able to make a short performance on a topic, some other students can give some information by simple sentences and some students can only draw a picture about the topic of discussion. This is the sense of effective teaching - to give each student an opportunity to express him $\backslash$ herself and make whatever helshe could.

In this case students learn to use foreign language practically in real situations, they study how to communicate and cooperate in solving any problem. By such method students practice to find the information, solve problem, choose the best variant etc. in foreign language and in extreme conditions. Moreover, students learn to listen to other participants, respect and take into account others thoughts and opinions.

The interactive teaching can differ by the students' level and teacher's desire to spend time for preparation, the classic example of interactive teaching is a topic "Directions". On the first level, teacher can give or show (on the blackboard, whiteboard, cards, monitor, etc.) lexicology for asking the way and students must practice it working in pairs or small groups. On the next level, teacher do the same (give the information) and ask students to model the situations. Names of different places can be on the cards and students must imagine the situation on the street: they have to ask the direction and give the instruction. The upper level - teacher takes his students to the street and they practice their vocabulary in the real world. The only problem is the absence of native speakers on the street, but students act in the real situation. Teacher can't model all possible answers of the people in the street and students don't know the possible reply.

The most interesting fact is that in most cases teacher becomes not even the adviser but the sterling participant of the process. Of course it depends on the teacher but very often author trying to help and motivate students do everything with them.

There are a lot of exercises and tasks for interactive language teaching. Among them are: brainstorm, aquarium, discussion, etc. The most interesting is discussion. First of all, discussion guarantees spontaneity. Teacher can divide students into small groups, give them the same topic or problem to solve and then compare their 
answers. If teacher is ready and is sure that his students are also ready he can give topic for the whole class. Everything depends on the teacher and his aim.

DOI 10.36074/29.11.2019.v4.10

\section{LEGISLATIVE PROVISION OF PRIMARY SCHOOL TEACHER TRAINING IN THE BENELUX COUNTRIES AND UKRAINE}

Tetiana Holovatenko

Lecturer of the Department of Foreign Languages and Methodologies, PhD student Borys Grinchenko Kyiv University

UKRAINE

Introduction. Recently, considerable attention of scholars has been paid to reforms of teacher training system in Ukraine. It has been noticed, that Ukrainian higher education develops in the transnational context [2] and a great influence is played by the European educational discourse [12]. This interest was enhanced by the "Association Agreement between the European Union and its Member States, of the one part, and Ukraine, of the other part". Through Articles 431 of the chapter "Education, training and youth" the following priorities are set: "... reforming and modernising the higher education system, promoting convergence in the field of higher education deriving from the Bologna process; enhancing the quality and relevance of higher education; stepping up cooperation between higher education institutions; building up the capacity of higher education institutions" [1]. Thus, to bring Ukrainian higher education closer to European standards, Law «On Higher Education» (2014) and Law «On Education» (2017) were adopted. One of important tasks on a state level was introduced in both of them: not only to integrate into EHEA (European Higher Education Area), but also to save national traditions in education [11].

At the same time, S. Sysoieva and N. Mospan notice these laws are a part of wide context of education reforms formulated in "Strategy of higher education reforming in Ukraine to 2020" [16]. It aims to modernize higher education and integrate into the EHEA and ERA (European Research Area) [14].

To further bring modernization of higher education into teacher training process, the "Conception of Reforming Pedagogical Education" was introduced by the Ministry of Education and Science in 2018. It aims at creating of a modern model of a pedagogical profession, finding perspective ways of continual teacher training and their in-service advanced training [13]. However, forming the content of teacher training is the responsibility of educational institutions.

So, Ukrainian teacher training system undergoes a series of reforms to unify it with the European system. At the same time there is lack of research on positive experiences of other European countries in resolving the issue. Considering abovementioned, we find it necessary to study European experience of legislative provision of primary school teacher training.

The aim of the article is to compare and identify the main similarities and differences between legislative provision of primary school teacher pre-service training in Belgium, the Netherlands, Luxembourg and Ukraine. 
Legislative provision of teacher training in Flanders (Belgium). Belgian higher education system is decentralized. It is managed in Flanders, Wallonia and German-speaking region according to the EU regulations, priorities of Benelux union, and state priorities in education. As rights to manage educational policies is devolved to language communities [8], we are going to analyze legislative provision of all three language communities.

In all three communities, a degree in Education to teach at primary schools, students can get at ISCED 6 level. It comprises Bachelor's or equivalent level programs lasting for 3 or 4 years [17].

The main legislative provision act for the system of higher education in Flanders is "Codex Hoger Onderwijs" (2014). According to it, students can get an academic higher education to work at secondary school within programs offered at a university. More practical approach is offered at colleges (called Hogeschool), which were certified by state authorities to prepare future primary school teachers. According to Article II.64, students should accumulate at least 180 ECTS credits to get a degree [3]. After Professional Bachelor's programme, students can apply for a one year Subsequent Bachelor. Finally, students can apply for 2 or 3 years Academic Bachelor's programme at universities [3].

One of peculiarities of Flemish higher education is a wide network of associations, made up of both universities and Hogeschools. According to "Codex Hoger Onderwijs" (2014), there are 5 of them: Ghent University Association, KU Leven Association, Antwerp University Association, and Brussels University Association [3]. These associations aim to optimize educational programs, reduce the amount of courses offered as a specialization, introduce flexible educational routes between Bachelor's and Master's programs, monitor the educational process to raise its quality, further develop research activities in Hogeschools and intensify involvement of employers into the educational process [20]. Moreover, through these associations Flanders cooperates with the Netherlands in terms of academic mobility and higher education quality control.

Besides the law on higher education, there is a decree "On teacher training in Flanders" (15.12.2006). This decree amends previous legislative acts concerning universities, university colleges, teacher education and in-service training, primary education, secondary education, adult education matters, the teaching duties of teachers, and restructuring of higher education in Flanders.

According to this degree, during the pre-service practical training and internship at school, each student is supported by a mentor. According to Article 7.4, within the available budget, the Flemish Government allocates resources for mentoring to centers, institutions or schools that belong to one of the following institutions: a school community in primary or secondary education; a school group; a cooperation platform between two or more of the following bodies: school communities in primary or secondary education; school groups; schools for mainstream and / or special primary education, insofar as these do not belong to a school community in primary education; an educational institution (s) for mainstream secondary education, insofar as these do not belong to a secondary school community; educational institutions for special secondary education; adult education centers; institutions for part-time art education.

One of the peculiarities of Belgian teacher training is a wide autonomy of higher educational institutions, which organize teacher training according to "soft law" and "hard law" regulations, offered to them. So, the content of teacher training curriculum 
is formed by universities or hogeschools. The same implies not only to Flanders, but to Wallonia as well.

Legislative provision of teacher training in Wallonia (Belgium). The main laws of the French-speaking community, concerning higher education are as follows: Decree of 31 March 2004 defining higher education, favoring its integration into the European space and refinancing universities, Decree of 5 August 1995 setting the general organization of higher education in High Schools, Decree of 5 September 1994 on the system of university and academic degrees, Act of 7 July 1970 on the general structure of higher education, Decree of 31 March 2004 defining higher education, favoring its integration into the European space and refinancing universities. We are going to focus our attention on the latest decrees, as they reflect the current educational policies.

According to "Decret du 31 mars 2004 definissant l'enseignement superieur, favorisant son integration a l'espace europeen et refinancant les universities" the system of higher education in French-speaking community consists of university and non-university education. Future primary school teachers can get academic education at universities and practically-oriented education at higher schools (hautes ecoles) authorized by state [4].

Organization of teacher training in higher schools (hautes ecoles) is based on Decree of 5 August 1995 setting the general organization of higher education in Higher Schools. Higher schools provide short- and long-cycled Bachelor's programs. As it defines, only those, who have a certificate of an obtained full secondary education and demonstrate good command of French, can be admitted to Higher Schools. Interestingly, higher schools work only according to the principle of territoriality. However, Article 49 regulates the minimum amount of students a higher school must have regularly. The overall amount varies from 700 to 1600 students, according to the area where the institution is located [5]. Students can get the diploma in at least three years.

Legislative provision of teacher training in the German-speaking community in Belgium. The only institution in German-speaking community, preparing future primary school teachers is the Autonomen Hochschule in der Deutschsprachigen Gemeinschaft. According to the «Decree on creation of the Autonomous Hochschule on 27.06.2005», students study professionally oriented courses, do researches and can choose additional specialization among French as foreign language, Basics of Catholics Religion, Ethics and Special Pedagogics [6].

One of peculiarities of pedagogical education in German-speaking community is a one-year practical training called referendariat. It comprises 1280 classes in primary school lasting 50 minutes each [6]. It is similar to referendariat offered for future teachers in Germany.

Legislative provision of teacher training in the Netherlands. According to the Higher Education and Scientific Research Act (1992), Dutch higher education consists of universities and university colleges, thus forming a binary system. Primary school teachers can get their qualification in both institutions. However, practically oriented courses are offered only in university colleges [18]. According to the Act on Teaching Professions, future teacher candidates undergo an obligatory competence screening process [19]. Future primary school teachers are offered a list of statements to comment on them with further projection of situations where they acted according to them. It helps demonstrate knowledge, skills, attitudes, values and personal characteristics of future primary school teachers within such 
competencies as interpersonal, pedagogical, organizational, subject-related competencies. Moreover, before becoming in-service teachers, candidates should pass a period of a practical training and a suitability test [7]. It all contributes to a high responsibility of institutions within the process of teacher training. Further analysis of Dutch system of higher education showed us that quality control is one of its most important features. It is provided by Accreditation Organisation of the Netherlands and Flanders (NVAO). It is responsible for program quality assurance and accreditation in two independent educational systems due to their current connections within the Benelux union.

Legislative provision of teacher training in Luxembourg. State regulation of educational policies is the responsibility of two ministries and several departments [15]. School and professional training is the responsibility of the Ministry of National Education, Children and Youth, higher education is the responsibility of Ministry of Higher Education and Scientific Research. So, there is a high level of cooperation between these institutions to move educational system in the same direction.

According to Eurydice, the only state higher educational institution is University of Luxembourg. Law "On establishing of University of Luxembourg» (on 12.08.2003) has fulfilled 7 tasks: created the only state university in the country; amended the Law on 31.05.1999 on creation of research funds in private sector фонду досліджень у приватному секторі; cancelled the law on 11.08.1996. on reforming higher education; amended law on 06.08 .1990 on organization of studies of social subjects; added amendments to the Act on 24.05.1989 on recruiting employees; added amendments to the Act on 06.09.1983 On Reform of the training of primary school teachers; establishment of the Higher Institute for Studies and Pedagogical Research; modification of the organization of pre-school and primary education, and added amendments to the Law on 04.12.1967 concerning incoming tax.

The Act on 06.09.2019 «On Reform of the training of primary school teachers; establishment of the Higher Institute for Studies and Pedagogical Research; modification of the organization of pre-school and primary education» regulates conditions to admit students to university studies; awarding educational degrees to future primary school teachers; conditions to access the teaching profession; and selection of employees on pedagogical positions after university studies.

To be enrolled into studies, besides having a certificate for secondary studies, students should be fluent in three state languages and be under 35 years old [10].

As researchers mention, educational management in Luxembourg is decentralized [9]. However, issues concerning the content of teacher training are devolved to the university.

Conclusions. We have analysed the legislative provision of teacher training in Belgium, the Netherlands, Luxembourg and Ukraine. Among some of its similarities, there is decentralization of educational policies in Belgium, the Netherlands and Ukraine. In the Netherlands and Belgium, future primary school teachers are prepared in university colleges (hogeschools or higher schools). In Ukraine future teachers are prepared in both university colleges and universities. In Luxembourg teachers are prepared only in universities. Most often, higher schools offer more practically-oriented education. Some of legislative acts provide specific requirements for the admission of teachers, their practical training. At the same time, educational institutions form the content of teacher training curriculum on its own. 
We can state there is a solid background for our further research of these countries, as they have some similarities. Our next task is to compare similarities and differences of future teacher training programs in abovementioned countries.

\section{References:}

1. Association Agreement between the European Union and its Member States, of the one part, and Ukraine, of the other part. (2014). Retrieved from https://eur-lex.europa.eu/legalcontent/EN/TXT/PDF/?uri=CELEX:22014A0529(01)\&from=EN

2. Avsheniuk, N. (2011). Sotsialno-ekonomichni determinanty rozvytku transnatsionalnoi vyshchoi osvity na zlami XX-XXI stolit [Social and econimical determinants of transnational higher education development on the edge of XX-XXI century]. Comparative professional training, $\mathrm{pp}$. $52-61$.

3. Codex Hoger Onderwijs. Retrieved from Flemish Ministry of Education and Training: https://dataonderwijs.vlaanderen.be/edulex/document.aspx?docid $=14650$

4. Décret définissant l'enseignement supérieur, favorisant son intégration dans l'espace européen de l'enseignement supérieur et refinançant les universités. Retrieved from https://www.gallilex.cfwb.be/document/pdf/28769_017.pdf

5. Decret du 5 aout 1995 fixant l'organisation generale de l'enseignement superieur en Hautes Ecoles. Retrieved from https://www.gallilex.cfwb.be/document/pdf/19109_002.pdf

6. Dekret Zur Schaffung Einer Autonomen Hochschule. Retrieved from http://www.pdg.be/PortalData/4/Resources/downloads/koordek/2005-06-27-01.pdf

7. Interimwet zij-instroom leraren primair en voortgezet onderwijs. (2000). Retrieved from https://wetten.overheid.nl/BWBR0011469/2004-09-01

8. Kriazhev, P. (2008). Tendentsii reformuvannia vyshchoi osvity v krainakh Zakhidnoi Yevropy [Tendencies of Reforming Higher Education in Western European Countries]. Kyiv: Institute of Higher Education of Academy of Pedagogical Sciences of Ukraine. p.10.

9. Krystopchuk, T. Ye. (2013). Pedahohichna osvita v krainakh Yevropeiskoho Soiuzu [Pedagogical education in the countries of the European Union]. Rivne, Ukraine: Volynsjki oberehy.

10. Law of 6 September 1983 on (a) reform of the training of primary school teachers; (b) establishment of a Higher Institute for Studies and Pedagogical Research; (c) modification of the organization of pre-school education and primary education. (1983). Retrieved from http://data.legilux.public.lu/eli/etat/leg/loi/1983/09/06/n1/jo

11. Law of Ukraine "On Higher Education". Retrieved from http://zakon2.rada.gov.ua/laws/show/1556-18

12. Lokshyna, O. (2018). Zabezpechennia yakosti vyshchoi osvity v umovakh yevropeizatsii Ukrainy. [Higher Eduaction Quality Assuarance in terms of Europization of Ukraine]. Continuous professional education: theory and practice (№ 3-4), pp. 127-132.

13. Ministry of Education and Science. (2018). Kontseptsiia rozvytku pedahohichnoi osvity [Conception of developing pedagogical education]. Retrieved from https://mon.gov.ua/ua/npa/pro-zatverdzhennya-koncepciyi-rozvitku-pedagogichnoyi-osviti

14. Ministry of Education and Science. (2014). Stratehiia reformuvannia vyshchoi osvity v Ukraini do 2020 roku [Strategy of reforming higher education in Ukraine to 2020]. Retrieved from https://mon.gov.ua/storage/app/.../18-strategiya-reformuvannya-vishhoi-osviti-20.doc

15. Samokhval, O. (2017). Osoblyvosti formuvannia ta realizatsii derzhavnoho upravlinnia profesiinoiu osvitoiu maibutnikh fakhivtsiv turystychnoi haluzi u Liuksemburzi [Peculiarities of forming and implementing public administration of vocational training of future specialists in tourism in Luxembourg]. Educology (6), pp. 181-186.

16. Sysoieva, S. O. (2015). Novyi Zakon Ukrainy Pro vyshchu osvitu: novovvedennia ta ryzyky [New Law of Ukraine "On higher education: innovations and risks]. Proceedings of Mykhailo 
Kotsiubynskyi Vinnytsya State Pedagogical University. Series: Pedagogy and Psychology (43), pp. 16-19.

17. UNESCO. (2011). ISCED 2011. Retrieved from http://uis.unesco.org/en/topic/internationalstandard-classification-education-isced

18. Wet op het hoger onderwijs en wetenschappelijk onderzoek. Retrieved from https://wetten.overheid.nl/BWBR0005682/2019-02-01

19. Wet op de beroepen in het onderwijs. (2004). Retrieved from https://wetten.overheid.nl/BWBR0016944/2013-07-04

20. Zakaulova, Yu. V. (2017). Rozvytok systemy profesiinoi osvity Belhii za chasiv hlobalizatsii. [Developent of the system of professional education in Belgium in the epoch of globalisation]. Miscellany of Kherson State University. Pedagogical Sciences., 75(2), pp. 101-107.

\section{MUSICAL THERAPY AS A MEANS OF CORRECTION OF PSYCHOPHYSICAL DISORDERS OF CHILDREN}

\section{Tsuranova Oksana}

Ph.D. in Musical Art, Associate professor Public Institution "Kharkiv Humanitarian Pedagogical Academy»

Yaroslava Polynko Public Institution «Kharkiv Humanitarian Pedagogical Academy»

UKRAINE

Music therapy for children with special needs in an inclusive environment, together with the common purpose and objectives of music education, aims at the realization of a specific task - the correction of psychophysical disorders of children, in particular the correction of their psycho-emotional state. Music has a positive effect on the autonomic nervous system of the child, is a stimulator of thinking processes and a stabilizer of communicative relationships between adults and children.

All types of corrective and developmental work meet the individual needs of each child. The personal approach, available methods and appropriate forms of musical and pedagogical influence on the child will help to resolve questions regarding the development of the emotional-volitional sphere, attention, intelligence. Listening to music is recommended not only during the class, but also during play or study activities or to set the children up for rest. Children should be dosed with music. For example, initially as a background to 15 minutes, one or two tunes, repeating them from time to time, but every day. That is, it goes from simple to difficult and when children start to learn music, they listen to new works.

Choosing music for lessons with children with various disorders of psychophysical development is difficult. That is why we propose to focus on works of classical and folk music, which are the basis for the formation of the musical culture of personality. Specificity of children's musical folklore is in accordance with the age possibilities of preschool children in the choice of themes, images, ideas; characterized by a combination of verbal material with game elements and 
accompanying movements; manifested through the expressed educational direction. Full of special national colourite, the music material is undoubtedly healing. Listening to music, you instantly understand the depth of art, its connection to national roots. First of all, it is energy that is radiated and perceived, and therefore creates a special state of mind that helps the baby with special needs to achieve positive results in the treatment, rehabilitation and normalization of the psychophysical state.

The content of music therapy classes is the unity of such positions as the enrichment of the experience of emotional and personal attitude to reality and the increase of the baggage of musical impressions. It is very important to cultivate a culture of listening to children and a desire to engage in artistic and musical practice in order to achieve their liberty, independence in their preferences, and most importantly, through music, to love and perceive themselves and the world as they are.

Classes in music therapy can contribute to the overall development of the child's personality. Emotional responsiveness and advanced musical hearing allow children to respond to good feelings and actions in an accessible form, help to activate cognitive activity, constantly improving the movement to the overall healing of the whole organism as a whole. There are no special warnings for using music therapy. However, the teacher should take into account the individual characteristics of each child with psychophysical disorders, given that in the general severe condition of the child, acute illness, severe lesions of the nervous system, the child is extremely vulnerable and requires special approaches in any method of therapeutic therapy. It is worth conducting music therapy classes in a room where children feel comfortable and cozy, equipped with the necessary visual aids and technical equipment.

Thus, the use of music therapy in the work with children with special needs in an inclusive environment in its various forms and forms as a multifunctional means of correcting psychophysical disorders is extremely important for normalization of their life. In the educational process of the institution, where the development and training of children with various disorders of psychophysical development are actively taking place, it should take a proper place. Because the introduction of nonstandard, creative, non-medical means of influencing the activation of the internal resources of the body of a child with psychophysical disorders creates more chances for its development.

References:

1. Alvin, J. \& Warrick, E. (2004). Music therapy for children with autism. Moscow: Terevinff.

2. Antonova-Turchenko O. \& Drobot L. (1997). Musical psychotherapy: a manual-textbook. Kiev: ISMN.

3. Petrushin, V. I. (2000). Music Psychotherapy: Theory and Practice. Moscow: Humanities issue. VLADOS Center. 


\title{
REFERENCE RESOURCES WHEN ORGANIZING STUDENTS' INDEPENDENT WORK
}

\author{
Olena Karasyova \\ $\mathrm{PhD}$, Candidate of Pedagogical Sciences \\ National University of Pharmacy
}

UKRAINE

The leading position of the higher school at present is taken by students' independent work organization as it helps to develop students' independent thinking, various skills and abilities. With the help of reference resources students' independent work can be well-planed, predicted, controlled, self -checked.

The analyses of the studied materials $[1,2,3]$ have showed that reference resources such as dictionaries, teachers' books, methodological recommendations, web-sites play an important role when organizing students' independent work. For example, dictionaries can help organize students' independent work in class and at home while doing such tasks as to give a description or a definition of a word, to find its origin, derivatives, to study the structure and usage of a word. Students can have explanation of the word meaning in the students' language, a definition of the word and examples in the sentences in the proper field of studies. They can give full information for completing the tasks with checking the pronunciation, spelling and use of a word.

The analyses of the materials $[3,4,5]$ showed that self-training books can be effectively used when organizing students' independent work. They help develop students' own understanding of a language, motivate students' independent active thinking.

For example, such tasks as finding and matching the definition of the words, matching parts of the sentences logically, putting the words in the correct order, filling in the gaps, linking the phrases, paraphrasing, completing the sentences, choosing the correct answer, translation of the sentences in students' own language and vice versa are used in many guidelines for independent exam preparation. They help to organize and stimulate students' independent thinking, creativity, and ability for self-training and self-control, what is possible with the given instructions or directions, keys with answers and grammar tables with the necessary information.

The references can help teachers to foresee and understand the anticipated students' difficulties while planning a lesson and students' independent classwork.

The reference resources could help us to find a way to solve the anticipated problems what is important and necessary for progressive learning.

Planning students' independent work teachers may use teachers' resource books which contain extra activities for various lesson types. Teachers' books usually contain suggestions, direction, tasks for individual or group work which help better organize students' independent work, make it more interesting, and let it be productive. Teachers can find new approaches, interesting activities for students' independent work organization using supplementary materials focused on certain skills. Also, there are many websites with free content for teachers on different teaching topics.

So, reference resources are important and necessary at present day teaching as they help to activate students' independent work, develop thinking abilities, 
foresee anticipated problems, make the process of education informative, productive, and self-controlled.

\section{References:}

1. ESL Education: Strategies for teaching English language learners. (2019). Retrieved from https://education.cu-portland.edu/blog

2. Cranmer, D. (1996). Motivating High-Level Learners, Pearson Education Ltd.

3. Gear, J. Gear, R. (2014). Cambridge preparation for the TOEFL Test. Retrieved from available at www. cambridge. Org

4. Learning a Second Language with Multimedia Materials. Retrieved from http://www.cited.org/index.aspx.

5. Macsuga, Gage A, Simonsen, B. \& Briere D. (2012). Effective teaching practices that promote a positive classroom environment beyond behavior.

\section{THE FACTOR OF TEACHER'S PERSONALITY ON INCREASING INTEREST OF THE STUDENTS IN HISTORY LESSONS}

Kamolov Ikboljon Ilkhomjon ugli

a history teacher

Presidential school in Tashkent

Ergasheva Mukhayyo Ganijonovna

a history teacher

secondary school №1 in Buvayda district, Ferghana region

REPUBLIC OF UZBEKISTAN

No one can deny that the basis of the current system of general secondary education in our country mainly consists of theoretical knowledge. But having a look at the current trend of education in the world, it is not difficult to realize that this is wrong. This exactly explains why students are becoming more passive toward science, school, and career.

Unfortunately, such problems are often encountered in teaching history, also. The only answer to the question of how make a student who intends to become an engineer (pharmacist, linguist, mathematician, chemist, pilot, etc.) in the future being interested in learning history for his/her future, not for the sake of grading or passing the state exam can possibly be the solution to these problems.

In this regard, the role of the teacher of science who teaches students is invaluable. Because it is the teacher's personality that shapes the student's view about the subject. This imposes a very serious responsibility on the teacher.

Below we will explain 5 features that need to be accepted by future educators who want to become history teachers.

First and foremost, the teacher should be an example to the student in every way. In other words, it is always important to make a positive impression on the students by his appearance, fluency, worldview, responsiveness and communication skills.

Some teachers do not have the responsibility to pay sufficient attention to their appearance. However, according to the Resolution of the Cabinet of Ministers of 
the Republic of Uzbekistan № 666, a formal uniform for both teachers and students has been introduced $[1,2019.10 .21]$. From the point of view of world standards and from the point of view of our national pedagogical traditions, the teacher is encouraged to have a modest outfit, with any exterior decorations.

The high level of awareness of the teacher in the latest socio-political, cultural and educational news in the country and in the world is evidence of his active civic position.

In turn, this kind of awareness instills in the environment in which he/she is teaching. A history teacher, who first understands himself/herself how the varioues processes occuring in the world are related to the past events and help his/her students to understand it is a step closer to his/her goal.

In order to gain the competence of awareness, it is necessary to learn the culture of recieving information transmitted through local and foreign media, the Internet, radio and television. The following feature distinguishes a history teacher from other teachers, in other words, this is considered his/her "business card".

The extent to which a teacher's knowledge of foreign languages is taught gives students a sense of respect for the teacher and, consequently, for the subject he or she is teaching.

There is a growing need for learning foreign languages, which is common in the global information space and opportunities that can be achieved as a result of this are increasing. A disadvantage of a teacher in this area is the fact that at a time when students are keen to learn a particular language [2, 2019.10.21].

Admittedly, everyone's ability to learn foreign languages and be able to do so can vary. But experienced teachers are well aware that in the face of other difficult aspects of the teaching profession, this is nothing.

So, what foreign languages are currently being taught at a trendy rate?

Undoubtedly, having proper proficiency, understanding, analyzing information written in those languages, speaking confidently and fluently in on of the world's most popular languages such as English, Spanish, French, German languages and in Russian language, which is widely-used in our country makes the teacher's position in the eyes of the students a step further.

The artistic and aesthetic worldview of the teacher, his/her competence in the arts and culture surely have a positive impact on his or her position in the community, including the environment in which he is teaching. His level of knowledge in music, fine arts, dance, and sculpture is one of the factors that dictates his spiritual worldview.

For example, teaching a history teacher to help students learn about numismatics can be helpful in their own collection of coins (the same can be said about philatelia and bonistics). Similarly, in the context of globalization, teachers themselves need a high level of competence in providing aesthetic education for young people. Teaching students to enjoy art and culture monuments is an expression of emotional upbringing.

The fact that a teacher has a comprehensive knowledge of not only his own teaching, but also of other disciplines, makes his ideas sound. In particular, a history teacher is required to have a thorough understanding of such subjects as literature, geography, economics, and law.

For example, it is an effective way to encourage readers to read fiction on the same topic in order to better convey to readers a particular historical theme.

Or, geographical knowledge is needed to compare the ancient borders of countries and peoples with those of today. 
In explaining the social nature of a particular historical period, it may be necessary to interpret the economic relations inherent in that system.

Definitions of jurisprudence help to characterize the state system, laws, geopolitical features of the former states.

In addition, we must remember that the history of science is closely intertwined with a number of disciplines according to interdisciplinary approach. Today, information and communication technologies, subjects about computers and the Internet have been added to the list. All of this increases the responsibility of the teacher as an example.

Keeping in mind that the above five aspects are the most demanding qualities of a modern history teacher, we would like to emphasize that the teacher should always be on his or her own initiative and have a creative approach to their profession. Because, as the rapidly changing world is in every field, it puts new issues in front of pedagogy science and teachers working in it.

Only cadres with mentioned above 5 qualities who are based on their own knowledge and will, and most importantly, are dedicated to their profession, will be honored with the honorable title of mentor.

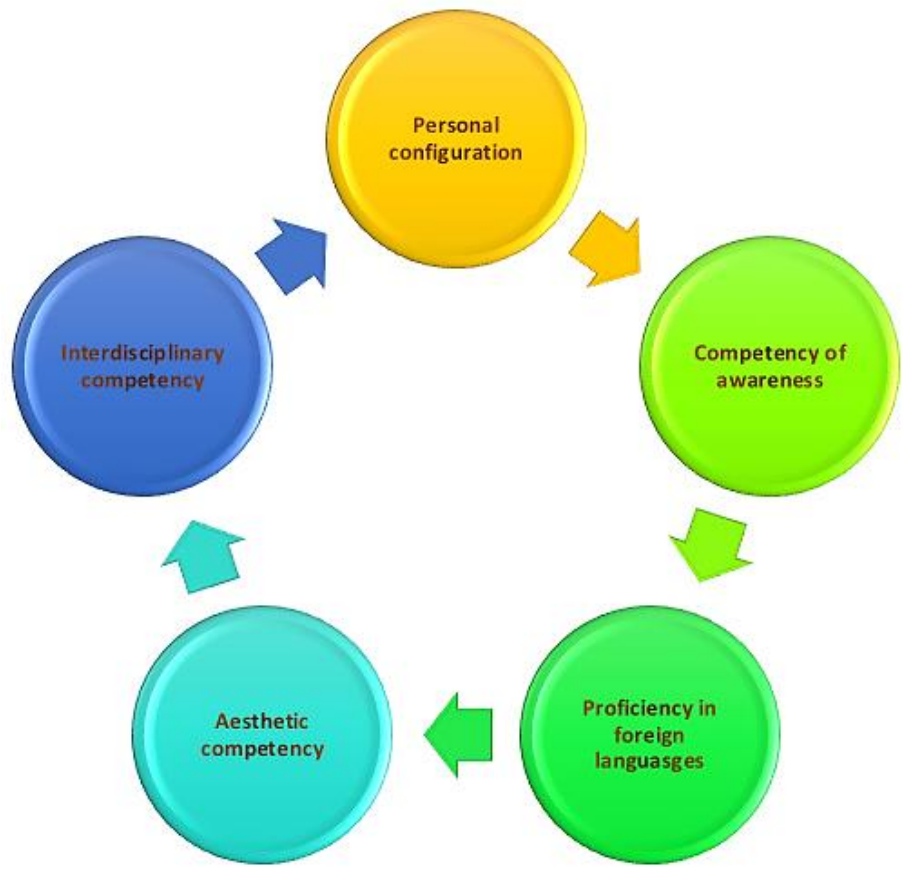

References:

1. National database of legislation of the Republic of Uzbekistan. Retrieved from http://lex.uz/docs/3866498.

2. National database of legislation of the Republic of Uzbekistan. Retrieved from http://lex.uz/docs/2126032. 


\section{VISUAL AIDS AS SUPPORT FOR THE COMMUNICATIVE COMPETENCY}

Olena Kozlova

Kamianske Medical College

UKRAINE

Could you take the modern process of learning without visual means in your head? Of course not. They can help students easily understand and comprehend the main points they are learning during the class. The use of visual materials during foreign language acquisition is a major teaching strategy. Promoting an interesting learning environment generates key competencies for students, which is the primary goal for foreign language teachers.

For the first time, the theoretical substantiation of the principle of clarity of education was introduced by the Czech educator Jan Amos Comenius. In his famous "golden rule of didactics", he stated that learning should begin "not with the verbal interpretation of things, but with the actual observation of them" [1]. Comenius understanding becomes a decisive factor in learning the material. Moreover, both insufficient and excessive use of visual aids are harmful: their lack leads to the formality of knowledge, and excess can hinder the development of logical thinking and imagination.

What is the benefit of visual learning? The visual materials give the students the opportunity to comprehend and remember concepts: the presentation of any concept using visualization gives students something that they can connect with the drawing. After, when they have to remember the concept, they just need to remember the image that was showed. Visualization helps store information for a long time: a picture is the simplest and most useful way to assure that information is stored in long-term memory, because words are processed by our short-term memory it can store only little amount of information. While our long-term memory processes images, where they become forever engraved. Visualization reduces teacher talk time: visual means help explain the meanings of different lexical units without explanation. You can also give the students the task to answer the questions about the used visual materials to motivate them to speak. With the visual aids, classes become more active and fun: students will be more active and emphasis will be removed from the teacher or text.

We have highlighted some of the advantages of using visuals; let's review some common and useful examples. Photos: the images are great for representing many lexical units. Students can be asked to describe what they see in the image and to predict what the text or section will be concerning the images on the page. Timeline: grammatical structures can be introduced through graphs and time charts. Tables and graphs: you can use a pie chart to illustrate the comparative and prevalent characteristics. Real facts and materials: an extremely useful visual tool for foreign language learning are real facts and materials. If the topic of the class is visiting a restaurant, with the real menu students will be more motivated. You can use this menu to familiarize students with new lexical elements and even as a framework for the role-playing. Here are some examples of real-life materials that can be used 
during a class: celebrity photos, train/subway/bus timetables, weather reports, hotel brochures, maps (world, country, streets, train, subway), menu, schedule of films/concerts, announcement, real estate ads, family trees, advertising. Infographics: they became very popular. Information graphics, infographics are a way of graphically displaying information aimed at quickly and accurately presenting the necessary and complex information. The advantage of informational graphics is that it allows you to easily and visually present a large amount of data. Its forms are cartoon, diagram, illustration, emblem, drawing, the timeline with a photo or links to certain information, tag cloud, maps, posters, diagrams and more. In teaching a foreign language, it is advisable to use infographics when activating lexical units, mastering grammatical phenomena, descriptions of drawings, modeling linguistic situations for the development of skills of monologic and dialogical speech, as well as for training in the use of lexical and grammatical material.

Visual aids are used actively to illustrate the country-specific material. It is very necessary and useful because it enables students to look where they have not been. This, in turn, stimulates the development of sociocultural competence of students.

Such learning tools as visualization are used in foreign language classes to create, first and foremost, support in the presentation of grammatical, lexical material, presentation of any situation that stimulates the development of students' communicative competence, i.e. the ability and willingness to exercise as a direct communication (speaking, hearing) and indirect communication (reading comprehension of foreign texts, writing). Communication is one of the most complex types of language activity, which is characterized by motivation. There are many ways to motivate students to communicate. One of the most effective is the use of visual aids. They solve the problems of motivating learning a foreign language in two ways at the same time. On the one hand, motivation (which is interesting in itself and enlivens the learning process) is embedded in the clarity of learning; on the other hand, it is an area where students can apply their knowledge, ability and learning skills [2].

\section{References:}

1. Коменский, Я. А. (1982). Избранные педагогические сочинения. Москва: Педагогика.

2. Thomas, M. \& Keinders, H. (Ed.). (2010). Task-based language learning and teaching with technology. London; New York: Continuum. 


\section{АНАЛІЗ ОСНОВНИХ ПЕРЕВАГ ВИКОРИСТАННЯ МОБІЛЬНИХ ЗАСТОСУНКІВ ПІД ЧАС НАВЧАЛЬНОГО ПРОЦЕСУ}

Тищенко Микола Андрійович

викладач

Національний технічний університет України «Київський політехнічний інститут імені Ігоря Сікорського»

УКРАЇ̈A

На сьогоднішній день вибір навчальних програм та застосунків може приголомшити будь якого викладача та студента. I ці застосунки використовуються не лише для розважальних потреб. Зараз користувач може знайти десятки тисяч прикладних програм для розвитку будь якого виду мовленнєвої діяльності, а саме:

- аудіювання;

- говоріння;

- письмо;

- читання.

Але, на жаль, ніхто з сучасних науковців у галузі методики викладання іноземних мов не робив зіставний аналіз переваг та недоліків використання програм та застосунків у навчальному процесі, що й робить подальше дослідження цього питання актуальним.

Говорячи про навчальну програму, слід розуміти прикладну програму яку встановлюють на персональний комп'ютер що працює на операційній системі Windows aбо Linux. Такі програми мають розширення файлу «.ехе», що означає, що користувачу потрібно купити носій 3 цією програмою чи завантажити з всесвітньої мережі Інтернет та, шляхом подвійного щиглика, встановити її на комп'ютер.

Даючи визначення застосунку, ми говоримо про програму, яку встановлюємо на планшетний комп'ютер чи смартфон. Встановлювальні файли для різних платформ $\epsilon$ різними, наприклад, для пристроїв на операційній системі Android це буде файл 3 розширенням «.apk» (від англійського Android Package), а для фрайлів на операційній системі iOS це буде файл з розширенням «.ipa» (iOS App Store Package).

Перевагою у встановленні застосунків над прикладними програмами, які можна використовувати для покращення навичок англомовного мовлення $€$ наступні:

- кроссплатформеність - застосунки можна встановити як на мобільний пристрій, так і на стаціонарний персональний комп'ютер (у цьому випадку потрібно встановити емулятор мобільної операційної системи);

- ціна - ліцензовані прикладні програми часто коштують дуже багато. У випадку із застосунками, викладач чи студент може знайти неймовірну кількість безкоштовного програмного забезпечення. Іноді розробники реалізують зменшення вартості своїх застосунків шляхом перегляду 
користувачем реклами, що, у свою чергу, можна віднести як до переваг, так і до недоліків їх використання;

- легкість у використанні - майже усі застосунки мають дружній до користувача інтерфейс та інтуїтивно зрозумілі інструменти використання програми, чого не скажеш про прикладні програми для стаціонарних персональних комп'ютерів на базі операційних систем Windows або Linux;

- відсутність вірусів - завантажуючи застосунок з офріційного ресурсу, користувач може бути впевненим, що програма пройшла перевірку на наявність вірусів. На жаль, це не можна сказати про завантаження прикладних програм з різних депозитаріїв, які можуть містити вірус, вбудований у виконуваний файл;

- синхронізація - під час використання застосунків, усі дані користувача зберігаються та синхронізуються завдяки унікальному обліковому запису і, наприклад, почавши виконувати завдання на планшетному персональному студент може закінчити виконання завдання на смартфоні. Такої переваги у прикладних програм нема, оскільки користувач, навіть у випадку, коли він має обліковий запис програми, повинен встановити та налаштувати прикладну програму на іншому стаціонарному комп'ютері.

Підводячи підсумки аналізу використання прикладних програм та застосунків, які викладачі та студенти можуть використовувати в освітньому процесі, ми можемо сказати точно, що розробникам освітнього програмного забезпечення потрібно зосередити свою увагу на інноваційних підходах у вивченні іноземної мови та створювати свої програмні комплекси для мобільних платформ.

\section{Список використаних джерел:}

1. Baker, D. S., Underwood, J. \& Thakur, R. (2017). Factors contributing to cognitive absorption and grounded learning effectiveness in a competitive business marketing simulation. Marketing Education Review, 27(3), 127-140. DOI: 10.1080/10528008.2017.1306710.

2. Blunsdon, B., Reed, K., McNeil, N., \& McEachern, S. (2013). Experiential learning in social science theory: An investigation of the relationship between student enjoyment and learning. Higher Education Research \& Development, 22(1), 43-56. DOI: 10.1080/0729436032000056544.

3. El-Hussein, M. \& Cronje, J. C. (2010). Defining mobile learning in the higher education landscape. Educational Technology \& Society, 13(3), 12-21.

4. McGovern, E. F., Luna-Nevarez \& C., Baruca, A. (2017). Utilizing mobile devices to enrich the learning style of students. Journal of Education for Business, 92(2), 89-95. DOI: 10.1080/08832323.2017.1281213. 


\title{
ВИКОРИСТАННЯ ТЕКСТІВ ПІСЕНЬ БРИТАНСЬКОЇ СПІВАЧКИ АДЕЛЬ НА ПРАКТИЧНИХ ЗАНЯТТЯХ 13 «СТИЛІСТИКИ АНГЛІЙСЬКОї МОВИ»
}

\begin{abstract}
Гурський Ігор Юрійович
викладач-стажист кафедри теорії та практики іноземних мов

Уманський державний педагогічний університет імені Павла Тичини
\end{abstract}

УКРӒ̈̈А

Вибудовування траєкторії профресійного становлення майбутніх учителів англійської мови НУШ є немислимим без опанування ними блоку теоретичних дисциплін англійської мови, серед яких якісно вирізняється навчальна дисципліна «Стилістика англійської мови». До основних завдань курсу слід віднести: ознайомлення студентів із палітрою лексичних, граматичних стилістичних засобів, характеристика їхньої ролі в авторському текстовому матеріалі; розгляд процесів становлення, розвитку стилів в англійській мові та їхніх вирізняючих рис: типових граматичних конструкцій, превалюючих лексичних одиниць.

Із метою прищеплення інтересу студентів до опанування дисципліни ми пропонуємо використовувати тексти пісень відомих британських виконавців у якості предмета стилістичного аналізу, оскільки, на наш погляд, це не лише дозволить закріпити вивчений матеріал та перевірити рівень його засвоєння на практиці, але й уможливить імплементацію цікавого освітнього контенту для широкого кола майбутніх учителів англійської мови.

Уважаємо за доцільне використовувати текстові уривки із пісень британської співачки Адель, пісенні витвори якої $\epsilon$ своєрідними «саундтреками» життя слухачів. На наш погляд, у кожному текстовому матеріалі є прихований «код», який студенти зможуть «розшифрувати» під час аналізу використаних стилістичних засобів, за допомогою яких розкривається глибинні закутки душі співачки.

Із метою узагальнення та систематизації вивченого матеріалу ми пропонуємо використати нижче наведену вправу. Студенти мають визначити стилістичні засоби, які використані в наведених уривках, та охарактеризувати їхній стилістичний ефект:

Which stylistic devices are used in the following extracts from Adele's songs? Which stylistic effects do they produce?

1. «Sometimes it lasts in love but sometimes it hurts instead,

Sometimes it lasts in love but sometimes it hurts instead» («Someone like you») [1]

2. "Where love is lost, your ghost is found» («Turning tables») [2]

3. "There's a fire starting in my head» («Rolling in the deep») [3]

4. "But I set fire to the rain

Watched it pour as I touched your face

Well, it burned while I cried

Cause I heard it screaming out your name» («Set fire to the rain») [4] 
5. «Who would have known how bittersweet this would taste?» («Someone like you») [1]

6. «I braved a hundred storms to leave you» («Turning tables») [2]

7. «When the thunder calls for me» («Turning tables») [2]

8. «l've forgotten how it felt before the world fell at our feet» («Hello») [5]

9. "You still look like a movie

You still sound like a song» («When we were young») [6]

10. «I don't need your honesty

It's already in your eyes

And l'm sure my eyes, they speak for me» («All I ask») [7]

Викладач може запропонувати студентам здійснити стилістичний аналіз однієї із пісень Адель, наголошуючи на тому, що вони мають звернути увагу на те, які стилістичні засоби переважають та визначити, які образи в уяві слухачів вони викликають. Ми пропонуємо таку послідовність виконання завдання студентами:

1. Пояснення алгоритму виконання стилістичного аналізу викладачем.

2. Поділ студентів на пари.

3. Визначення предмету стилістичного аналізу студентами.

4. Стилістичний аналіз тексту обраної студентами пісні.

5. Презентація результатів дослідження.

6. Моделювання стилістичного портрету співачки.

Слід відмітити, що студенти мають представити результати своєї роботи у форматі мультимедійної презентації, інфограффіки, тощо. Важливим у контексті підвищення ефективності освітнього процесу $\epsilon$ те, щоб предмети стилістичного аналізу не повторювалися. Після презентації результатів досліджень студентів викладач пропонує студентам змоделювати уявний стилістичний портрет британської співачки на матеріалі результатів їхніх стилістичних аналізів.

Викладач має виступати в ролі модератора колективної творчої інтеракції студентів із метою створення середовища співпраці для ефективного навчання та розкриття творчого потенціалу кожного учасника освітнього процесу. Виконуючи ці завдання, студенти матимуть змогу продемонструвати не лише рівень засвоєння навчального матеріалу, але й здатність до продуктивної співпраці із іншим студентом у контексті досягнення спільної навчальної цілі - детального, глибокого аналізу тексту автентичного пісенного матеріалу. Крім того, студенти навчаться об'єднувати інтелектуальні зусилля у прагненні презентувати результати стилістичного аналізу стисло, лаконічно та нестандартно.

Підводячи підсумки, уважаємо за доцільне зауважити, що під час проектування цікавого освітнього контенту із навчальної дисципліни «Стилістика англійської мови» викладач має перебувати в пошуку оптимальних шляхів посилення синергетичного зв'язку теоретичної та практичної підготовки. На наш погляд, одним із таких шляхів $є$ використання текстів пісень британської співачки Адель на практичних заняттях в якості предмета стилістичного аналізу. Автентичний лінгвістичний матеріал, який може викликати зацікавленість студентів та його ефективне використання на практичному занятті, можуть постати механізмом для забезпечення 
результативності засвоєння навчального матеріалу із курсу «Стилістика англійської мови».

\section{Список використаних джерел:}

1. Genius. (2019). Retrieved from https://genius.com/Adele-someone-like-you-lyrics.

2. Genius. (2019). Retrieved from https://genius.com/Adele-turning-tables-lyrics.

3. Genius. (2019). Retrieved from https://genius.com/Adele-rolling-in-the-deep-lyrics.

4. Genius. (2019). Retrieved from https://genius.com/Adele-set-fire-to-the-rain-lyrics.

5. Genius. (2019). Retrieved from https://genius.com/Adele-hello-lyrics.

6. Genius. (2019). Retrieved from https://genius.com/Adele-when-we-were-young-lyrics.

7. Genius. (2019). Retrieved from https://genius.com/Adele-all-i-ask-lyrics.

\section{ВОЗМОЖНОСТИ ИСПОЛЬЗОВАНИЯ ПРОБЛЕМНОГО ОБУЧЕНИЯ В ПРОЦЕССЕ ИЗУЧЕНИЯ ИМЕНИ СУЩЕСТВИТЕЛЬНОГО}

Кон Олена Олександрівна

кандидат філологічних наук, доцент, доцент кафедри слов'янського мовознавства Південноукраїнський національний педагогічний університет

УКРАÏHA

Проблемное обучение предполагает последовательное и целенаправленное выдвижение перед учениками познавательных задач, разрешая которые они активно усваивают новые знания.

Задача становится познавательной проблемой, если она соответствует следующим требованиям:

1. Представляет из себя познавательную трудность для учащихся, т.е. требует размышлений над изучаемой проблемой.

2. Вызывает познавательный интерес в учеников.

3. Опирается на прежний опыт и знания учащихся по принципу апперцепции [1].

Основой проблемного обучения является проблемная ситуация. Она характеризуется определенным психическим состоянием учащихся, которое возникает в процессе выполнения задания, для которого нет готовых средств и которое требует усвоения новых знаний о предмете, способах или условиях его выполнения.

Центральным звеном проблемного обучения является такая категория, как «проблемность». Проблемность - психологическая закономерность мышления, и она проявляется в любом эффективно организованном учебном процессе. Форма проявления, степень использования проблемности в значительной мере и определяет тип учебного процесса, его структуру и методы [2]. 
Педагогическая практика показывает, что использование проблемной ситуации возможно при изучении почти каждой грамматической темы. Из проблемной ситуации может быть несколько выходов:

1) учитель сам ставит проблему и решает её;

2) учитель сам ставит и решает проблему, но при этом привлекает учащихся к формулировке проблемы, выдвижению предположений, доказательств гипотезы и проверке решения;

3) ученики самостоятельно ставят и решают проблему, но с участием и помощью учителя;

4) учащиеся самостоятельно ставят и решают проблему, но уже без помощи учителя (но, как правило, под его руководством).

Главная дидактическая трудность в создании проблемного задания заключается в том, что выполнение учениками данного задания должно привести их к потребности в том знании или способе действия, который составляет неизвестное.

Наибольшее применение в практике обучения получила общая для всех учебных предметов классификация (типология) проблемных ситуаций:

1. Проблемная ситуация возникает при условии, если учащиеся не знают способа решения поставленной задачи, не могут ответить на проблемный вопрос, дать объяснение новому факту в учебной или жизненной ситуации, т.е. в случае осознания учащимися недостаточности прежних знаний для объяснения нового факта.

2. Проблемные ситуации возникают при столкновении учеников с необходимостью использовать ранее усвоенные знания в новых практических условиях. Как правило, учителя организуют эти условия не только для того, чтобы учащиеся сумели применить свои знания на практике, но и столкнуть с фактом их недостаточности. Осознание этого факта школьниками возбуждает познавательный интерес и стимулирует поиск новых знаний.

3. Проблемная ситуация легко возникает в том случае, если имеется противоречие между теоретически возможным путем решения задачи и практической неосуществимостью избранного способа.

4. Проблемная ситуация возникает тогда, когда имеется противоречие между практически достигнутым результатом выполнения учебного задания и отсутствием у школьников знаний для его теоретического обоснования [3].

Метод проблемного обучения используются при изучении нового материала, расширении и углублении знаний на уроках закрепления, повторения и обобщения.

Наиболее известна система общих методов:

- Объяснительно-иллюстративный;

- Репродуктивный;

- Метод проблемного изложения;

- Частично-поисковый;

- Исследовательский метод [4].

При изучении имени существительного важнейшими являются следующие понятия: предметность, одушевленность и неодушевленность, родовая принадлежность и изменение по числам. 
Формирование грамматических знаний, умений, навыков осуществляется на различных этапах урока, таких как объяснение нового материала, закрепление (формирование умений и навыков) и проверка. На всех этих этапах не только возможно, но и необходимо использовать проблемную ситуацию, так как каждый раз решаются иные задачи и достигаются различные результаты [5].

На начальных уроках, посвященных имени существительному, дается представление о предметности, понимаемое не только как конкретный предмет (что учащимся начальных классов и так понятно), но и о предметах, выделяемых абстрактным мышлением, что вызывает затруднение в понимании.

На уроках объяснения предлагаются следующие задания, позволяющие ученикам самостоятельно вывести правило о том, что обозначает имя существительное.

Задание 1: Сравните правый и левый столбик.

Я сын своих родителей.

В портфреле лежат учебники и тетрадки.

Я кладу в пенал карандаши и ручки,

Учитель задает вопросы.

1. Обе ли записи слов являются предложением?

2. Если нет, то почему?

3. Какое слово нужно добавить, чтобы оно стало предложением?

4. Выпишите пропущенные имена существительные, задавая им вопрос.

Вывод: Слова, обозначающие предмет, отвечающие на вопросы кто?, что? называются именами существительными.

Задание 2. Дается цепочка слов:

Автобус, велосипед, Мария, Шарик, Волга, Киев, цветок, Вася, Одесса, Днепр.

1. Можно ли среди этих слов выделить две группы?

2. Если можно, то, по какому принципу? (по написанию).

Вывод: одни слова пишутся с большой буквы, а другие с маленькой. Почему?

3. В какие группы можно определить?
А) по именам;
Б) название городов, рек;
В) клички животных;
Г) транспорт.

4. На какой вопрос отвечают все эти слова.

Вывод: имена собственные - отвечают на вопрос что? I кто?. Существительные имена людей и клички животных отвечают на вопрос кто? Все остальные имена существительные отвечают на вопрос что?

Уроки закрепления по данной теме призваны решать задачи по умению выделять имена существительные от других частей речи.

На этапе закрепления основным средством создания проблемной ситуации служит интеграция вопросов и практических методов, позволяющих 
найти инвариантное решение поставленной задачи [6]. На этих уроках используются такие задания:

Задание 1. Из данных слов выпишите существительные.

Тепло, робкий, голова, смех, пес, весёлый, смешной, ученик.

Задание 2. Выпишите имена собственные:

Имя Виктория; Город Полтава; Гора Килиманджаро; Пустыня Сахара; Республика Крым; Фамилия Иванов; Река Нил; Море Каспийское.

Проверкой осуществляется контроль за прочностью усвоения полученных знаний, также за сформированностью грамматических умений и навыков. Ведущим средством проблемности на данном этапе является задание в виде текстов, где необходимо не только выбрать правильный ответ, но и его обосновать.

Задание 1. Подчеркните в тексте имена существительные и объясните ваш выбор.

Сосна растёт в лесу. Картофель молодой. Дети купаются на озере. Родители приехали на дачу.

Задание 2. Что такое имя существительное? Придумайте по 5 существительных на тему природы, школы, посуды.

Таким образом, используя проблемную ситуацию, можно вводить понятие одушевленности - неодушевленности, родовую принадлежность и изменение по числам [7].

Задание 3. Одной чертой подчеркните нарицательные имена существительные, а двумя собственные.

По парку гуляют ребята. Маша поскользнулась и упала. Внучка Настенька навестила свою бабушку. Сын подписал открытку маме.

Таким образом, использование проблемных ситуаций при изучении грамматических категорий имени существительного позволяет управлять мыслительной деятельностью учеников, что является необходимым условием для их всестороннего развития, самостоятельной учебной деятельности, повышения познавательной активности в процессе овладения знаниями. Включение школьников в самостоятельную поисковую деятельность под руководством учителя помогает овладеть элементарными приёмами самостоятельной работы.

Главная ценность состоит в том, что дети получают возможность сравнивать, наблюдать, делать выводы. Учащиеся убеждаются в том, что не на каждый вопрос есть готовый ответ, что ответ может быть неоднозначным, что каждый из них имеет полное право искать и находить свой ответ, отстаивать свое мнение.

\section{Список використаних джерел:}

1. Бабанский, Ю. К. (1985). Методы обучения в современной школе. Москва: Просвещение.

2. Загвязинский, В. И. (1971). Проблемность как воплощение движущих сил учебного процесса. Тюмень: ТПИ. 
3. Махмутов, М. И. (1975). Проблемное обучение. Основные вопросы теории. Москва: Педагогика.

4. Кукушин, В. С. (2005). Теория и методика обучения. Ростов-на-Дону: Феникс.

5. Мельникова, Е. Л. (2002). Проблемный урок, или Как открывать знания с учениками. Москва: АПКиПРО.

6. Лоншакова, А. А. (2002). Нестандартные приемы закрепления на уроках русского языка. Начальная школа, (4), 38-44.

7. Караева, С. А. (2014). Методика использования стихов с заданиями по теме имя существительное. Начальная школа, (2), 56-94.

\title{
ВПРОВАДЖЕННЯ ІННОВАЦІЙНИХ ТЕХНОЛОГІЙ НА ЗАНЯТТЯХ ОХОРОНИ ПРАЦІ
}

\author{
Дусматова Оксана Вячеславівна \\ викладач вищої категорії \\ УКРАÏHA
}

Індустріальний коледж Державного вищого навчального закладу Український державний хіміко-технологічний університет

Жодна людина не може постійно та безпомилково виконувати свої функції в процесі навчання, праці та в побуті. Тому підготовка студентів закладу освіти до безпечної праці та діяльності неможлива без своєчасного засвоєння знань з безпеки життєдіяльності й основ охорони праці.

У сучасній освіті один із пріоритетних напрямів розвитку $є$ інформатизація та впровадження комп'ютерних технологій у навчальний процес, що значно покращує якість та ефективність навчання майбутніх фахівців, підвищує конкурентоспроможність на ринку праці. Застосування комп'ютерних технологій потребує перегляду форм і методів навчальної діяльності. Слід пам'ятати, що комп'ютерні технології є ефективним, але допоміжним засобом навчання. Застосування комп'ютерних технологій підвищує активність студента, веде до перебудови навчального процесу в бік самостійних форм навчання.

Основи знань 3 охорони праці студенти здобувають під час вивчення відповідної нормативної дисципліни, яка вивчається з метою формування у них потрібного для їхньої подальшої професійної діяльності рівня знань та умінь із правових та організаційних питань охорони праці, основ фізіології, виробничої санітарії, гігієни праці, пожежної безпеки, а також активної позиції щодо практичної реалізації принципів пріоритетності охорони життя та здоров'я учнів щодо результатів виробничої діяльності. Пріоритетним напрямком дисципліни «Охорона праці» вважається набуття компетенцій щодо запобігання нещасним випадкам через формування соціальної позиції особи щодо її особистої безпеки та безпеки оточуючих. Світовий і український досвід показує, що навчання майбутніх кваліфікованих працівників безпечним прийомам роботи, вимогам охорони праці, надання першої допомоги 
потерпілим на виробництві є ефективним інструментом зниження виробничого травматизму та професійних захворювань.

Однією з причин смертності та захворюваності внаслідок впливу шкідливих виробничих фракторів $€$ недостатня проінформованість працівників про професійні ризики та вимоги охорони праці [3]. У даному контексті вдосконалення навчання охороні праці за допомогою впровадження в освітній процес інноваційних освітніх технологій продовжує залишатися актуальним напрямком діяльності закладів освіти.

Метою курсу «Основи охорони праці» у навчальному закладі $є$ надання знань, умінь, компетенцій для здійснення ефективної професійної діяльності шляхом забезпечення оптимального управління охороною праці на підприємствах, формування у студентів відповідальності за особисту та колективну безпеку і усвідомлення необхідності обов'язкового виконання в повному обсязі всіх заходів гарантування безпеки праці на робочих місцях. У структурно-логічній схемі навчання нормативна дисципліна «Основи охорони праці» вивчається на етапі підготовки фахівців при вивченні дисциплін професійно-орієнтованого циклу, коли майбутні фахівці мають достатнє уявлення щодо умов їхньої майбутньої професійної діяльності. Це забезпечує можливість викладання дисципліни «Основи охорони праці» з урахуванням професійної орієнтації студентів. Проте, в умовах традиційних форм і методів навчання, студенти, пасивно отримуючи знання, не можуть застосувати їх у реальних умовах. Така ситуація вимагає перегляду існуючих форм організації навчального процесу.

Bce це вимагає пошуку нових підходів до навчання охорони праці, яке повинно опиратися не на трансляцію готових знань, а на створення умов для інноваційної пізнавальної діяльності на основі наявного досвіду.

Інноваційний підхід забезпечує позитивну мотивацію здобуття знань, активне функціонування інтелектуальних і вольових сфер, сприяє розвитку творчої особистості та активізації розумової діяльності. Створення ситуації успіху, сприятливих умов для повноцінної діяльності кожного студента основна мета, що покладена в основу інноваційних технологій навчання. Багато з них варті уваги сучасного педагога, який прагне дати якісний рівень знань, зробити заняття цікавим, досягти максимального взаєморозуміння і співпраці між викладачем і студентом.

Серед інноваційних технологій, що доцільно використовувати під час викладання основ охорони праці можна виділити: метод проектів, дидактичні ігри, інтерактивні методи навчання, диспути, круглі столи, кейс-методики, метод портфоліо тощо $[4,5]$. Розглянемо декілька технологій, які найчастіше використовуємо під час викладання основ охорони праці.

Метод проектів містить у собі сукупність дослідницьких, пошукових, проблемних методів, творчих за своєю суттю, то цю технологію можна розглядати як технологію, що сприяє творчому розвитку учнів, використанню ними певних навчально пізнавальних прийомів, які в результаті самостійних дій учнів дають змогу вирішити ту чи іншу проблему. Крім того метод проектів передбачає обов'язкову презентацію результатів [6, 7].

Заняття, яке проведено нестандартно, стимулює творчість вчителя і його вихованців, створює сприятливі умови для співпраці студентів один з одним і 3 вчителем. Уроки прес-конференції розвивають активність, пошукові здібності, вміння розкривати суть певної проблеми, стисло і коротко 
висвітлювати ії, конкретно відповідати на поставлені питання. Вони вчать самостійно здобувати знання.

Всі ці методи не можуть існувати без допомоги інформаційних технологій. Мультимедійні засоби навчання надають великі можливості підвищення ефективності процесу навчання, оскільки забезпечують одночасне використання декількох каналів сприйняття, завдяки чому досягається інтеграція інформації; роблять можливою імітацію складних реальних ситуацій та експериментів; дозволяють візуалізувати абстрактну інформацію завдяки ії динамічному представленню; дозволяють впливати на розвиток якостей, що характеризують творче мислення.

У вирішенні питання навчання, самопідготовки і тестування з предмета «Охорона праці» був створений електронний навчально-методичний комплекс. Електронний навчально-методичний комплекс - сукупність структурованих навчально-методичних матеріалів, об'єднаних за допомогою комп'ютерного середовища навчання, які забезпечують повний дидактичний цикл навчання i призначених для оптимізації оволодіння студентом професійних компетенцій в рамках навчального предмета. До складу електронного навчально-методичного комплексу входять організаційнометодичний, змістовний та навчально- методичний блоки. Електронний навчально-методичний комплекс об'єднує в цифрровій фрормі текст, графрічне та відео зображення, на цій основі створюються нові засоби навчання

Наведені інноваційні методи та форми допомагають змінити акценти в процесі навчання студентів 3 установок на освітню підготовку - на персоніфікований, діяльнісний процес [1]. В процесі такої підготовки акцентується розвиваючий потенціал навчання, актуалізуються цінність пошукової діяльності та дидактичні цілі високого пізнавального рівня, набуває розвитку особистісно-професійна готовність до вирішення питань у професійній галузі, створюються педагогічні умови, при яких стимулюються творчі здібності студентів; моделюються елементи майбутньої професійної діяльності, формуються не тільки знання, вміння та навички з предмета, а загальнокультурні та професійні компетенції, активна життєва позиція та головний спонукальний мотив навчальної діяльності - професійний інтерес у поєднанні з самореалізацією й орієнтацією на розвиток особистих і професійно важливих якостей.

\section{Список використаних джерел:}

1. Кобилянський, О. В., Дембіцька, С. В. \& Кобилянська, І. М. (2014). Теоретичні засади формування компетенцій з безпеки життедіяльності у студентів економічних спеціальностей. Вінниця: ВНТУ.

2. Кобилянський, О. В. \& Дембіцька, С. В. (2014). Педагогічні умови використання інтернеттехнологій у процесі вивчення безпеки життєдіяльності. Сучасні інформаційні технології та інноваційні методики навчання в підготовці фахівців: методологія, теорія, досвід, проблеми: зб. наук. пр. Київ-Вінниця: ТОВ фірма «Планер».

3. Щербаков, В. И. (2011). Культура охраны труда и национальная безопасность. Охрана труда и техника безопасности на промышленных предприятиях, (3), 44.

4. Шевченко, Л. С. (2014). Застосування інноваційних педагогічних методик майбутніми учителями технологій. Сучасні інформаційні технології та інноваційні методики навчання в підготовиі фахівиів: методологія, теорія, досвід, проблеми: зб. наук. пр. Київ-Вінниця: ТОВ фірма «Планер». 
5. Шевченко, Л. С. (2014). Розвиток поняття «педагогічні технології» в педагогічній науці та практиці. Сучасні інформаційні технології та інноваційні методики навчання в підготовці фахівиів: методологія, теорія, досвід, проблеми: зб. наук. пр. Київ-Вінниця: ТОВ фірма «Планер».

6. Дембіцька, С. В. \& Кобилянська, І. М. (2016). Управління пізнавальною діяльністю студентів під час вивчення безпеки життєдіяльності шляхом впровадження методів проектного навчання. Педагогіка безпеки, (1), 53-58.

7. Гуревич, Р. С., Кадемія, М. Ю. \& Шевченко, Л. С. (2007). Навчання у телекомунікаційних освітніх проектах (з досвіду роботи). Вінниця: ТОВ «Ландо ЛТД».

\title{
ДО ПРОБЛЕМ ОРГАНІЗАЦІЇ ОСВІТНЬОГО ПРОЦЕСУ НА УРОЦІ ХОРЕОГРАФІЇ
}

\begin{abstract}
Алтухов Вадим Анатолійович
канд. пед. наук, доцент кафедри хореографії

Харківського національного педагогічного університету імені Григорія Сковороди

УКРАÏHA
\end{abstract}

Актуальність статті полягає в тому, що сьогодні управління якістю освіти це одна з актуальних і найбільш активно обговорюваних проблем в Україні. Так, традиційна система організації навчального процесу на уроці хореографії не враховує багато факторів, які могли б поліпшити умови навчання, а через них підвищити ефективність освітньої діяльності педагогів-хореографів.

Аналіз наукової літератури показує, що більшість досліджень в області хореографії мають - культурологічний характер (Г.Ф.Богданов, І.О. Дубнік, В.І. Уральська та ін.), що визначає роль мистецтв у розвитку особистості (А.М. Столович, В.Н. Семенов, В.С. Селіванов, та ін.).

Загальнотеоретичні засади професійної підготовки студента-хореографа викладені в працях А.Я. Ваганової, К.Я. Голейзовського, Р.В. Захарова, Ф.В. Лопухова, А.М. Мессерера та ін.

Серед сучасних педагогічних досліджень, присвячених проблематиці хореографічної освіти, виділяються: докторські дисертації В.Ю. Нікітіна, В.Н. Нілова, та ін., присвячені вузькопрофесійним аспектам діяльності хореографа, серед яких організація освітнього процесу на уроці хореографії не розглядалась. Це визначило тему даного дослідження «До проблем організації освітнього процесу на уроці хореографії».

Мета дослідження: розкрити шляхи до рішення проблем організації освітнього процесу на уроці хореографії

Завдання дослідження:

- проаналізувати психолого-педагогічну і методичну літературу;

- визначити загальні характеристики уроку;

- розглянути думку деяких діячів хореографії на організацію освітнього процесу на уроці хореографії.

Виклад матеріалу. Розмірковуючи над проблемами організації освітнього процесу на уроці хореографії, ми не можемо не звернути уваги на те, що на 
кожному уроці присутня і цілісність, і логічна завершеність, і обмеженість тимчасовими рамками, і план роботи, і кількість учасників. Урок - це, безперечно, показник: роботи вчителя та учнів. Якщо мова йде про звичні зовнішні (формальні) ознаки цієї роботи, то тут ніяких проблем немає: особливих складнощів для будь-якого вчителя не буде, щоб продемонструвати всі зовнішні показники успішності своєї діяльності: і логіку, і чіткість, і організованість, і відповідність заняття плану. І навіть - зовсім туманний «аспект взаємодії сім'ї та школи».

Ми ж дотримуємося дещо іншої думки про урок, представляючи його в якості головної форми організації навчального процесу: форма, яка представлена в сучасній педагогіці як зовнішній вигляд, зовнішнє окреслення. Таке розуміння форми знімає необхідність звертатися до того, як вважає С. B. Кульневич, «...що поняття форми в першу чергу залежить від того, що вона оформляє, чому вона надає певний вид. Ці "що" і "чому" - зміст, форма - це те, що виражає зміст. Причому не тільки структурний зміст уроку - організаційний момент, постановку мети, опитування, завдання тощо, але й те, на чому все це стоїть, з чого виникає, які цінності для особистості, що розвивається. Тому мова повинна вестися про цілісність уроку, як єдності його фоори та змісту» [1].

Погоджуючись 3 автором, ми встаємо на позицію того, що в сучасній педагогіці урок не $є$ умовою реалізації цілісності освітнього процесу. Однак необхідно звернутися до специфріки даного дослідження і виявити особливості хореографрічного уроку, який в силу своєї художності, не завжди відповідає тенденціям і положенням загальної дидактики.

Поява концепції В. М. Нілова про хореографічну освіту й заснованих на ній програми та методичного посібника стало помітним явищем в педагогічному житті. Таким чином, В. М. Нілов вивів систему хореографрічної освіти на новий рівень мислення, де культура мислення формується в процесі пізнання шкільного «предмета», який сам $є$ сховищем духовності, «всього найкращого, що передумало, та пережило людство», і при цьому розглядає життя і мистецтво у фрілософрському аспекті. Тому немає іншого шляху, окрім як перевести викладання хореографічного мистецтва на філософський рівень [2].

Розглянемо приклади того, як на практиці сучасними вчителями хореографії здійснюється процес викладання і якого рівня мислення розвивають вони в учнях на своїх уроках. Перше, що доводиться відзначити, це примітивізація змісту хореографрічного мистецтва в загальноосвітній школі. На жаль, багато хто вважає, що урок хореографії в школі повинен мати характер радісного дійства, де учні можуть якщо не відпочивати, то виходити з уроку лише з позитивними враженнями.

Іншу варіацію на тему «урок хореографії» пропонують сьогодні педагоги так звані послідовники системи елементарного розвитку творчих здібностей школярів. Урок хореографії наповнюється різними пластичними рухами, що визначають настрій музики та засоби виразності, він сповнений творчими ритмічними імпровізаціями тощо.

Ще один момент, на який страждає сучасна хореографічна освіта, - зайва затеоретизованість. Подібне теоретизування на уроках хореографрії у загальноосвітній школі слід обмежувати «почуттям міри у викладі фактів, цифр, цитат» [4]. 
Наступною крайністю все тієї ж зайвої теоретизації $€$ той факт, що уроки хореографрії в школі відрізняються насиченою інформацією, високим темпом роботи, підвищеною інтенсивністю навчально-пізнавальної діяльності учнів, різнобічністю видів творчої діяльності.

Таким чином, урок хореографії зводиться до простого виконання рухів, до суми видів діяльності та організаційних перестановок. І якщо на кожному такому уроці, знайомлячись з новим хореографічним твором, учні й будуть говорити про зміст, форми, фактури, засоби виразності, то це все ще залишиться просто термінологічно оформленою констатацією знань. А оскільки така розумова діяльність йде поза єдності зі змістом, а також поза єдності приватних проявів у контексті загального цілого - художньої ідеї твору, то подібна практика якщо й не шкодить, то точно не розвиває мислення учня.

Всі ці позитивні досягнення науки, в тому числі й останніх років як і раніше не знаходять практичного застосування в школі. Вихід на проблемність художнього задуму, на діалектичність всередині ідеї твору мистецтва, на змістовність досліджуваної форми існує лише в рідкісних роботах, мало того, зустрічає нерозуміння та неприйняття з боку сучасних теоретиків.

Так, Н.І.Тарасов в розділі «Школа», дає рекомендації молодим викладачам хореографрам, з чого починається та як проходить процес формування, створення уроку хореографії, центральним моментом якого $є$ реалізація «творчого задуму», ідеї уроку. Що ж автор має на увазі під задумом уроку хореографіiі?

«Розробляючи урок хореографії, - пише Н. І. Тарасов - треба пам'ятати, що їхня ідея може залежати не тільки від програми та педагогічного завдання, що стоїть перед учителем, а й від часу, коли рекомендована програма освоюється» [4].

Не можна не погодитися з тією думкою, що «задум уроку покликаний враховувати сучасний стан культурних обставин в суспільстві, сьогоднішнє ваше та ваших учнів сприйняття життя та хореографії як частини цього життя».

Важливо, вважає автор, щоб в концепції серії уроків проходила нитка, що демонструє престижність освоєння хореографрічного мистецтва, що б «у хлопців з'явилася б позитивна мотивація до хореографрічного утворення» [4].

Однак всі ці рекомендації мають приватний характер, щоб бути зведеними в ранг задуму уроку хореографії. Причому тут престижність та сучасність, якщо хореографрія не мислить цими категоріями й ніколи не стане засобом популяризації особистості в сучасному суспільстві. Чи не ця мета рухала мільйони людей до освоєння та причетності до хореографрічного мистецтва, але внутрішня сутність, її емоційна природа, адекватна природі людської душі, людської думки, людського всередині пристрою. І ці основи не можуть піти 3 часом або перестати бути актуальними сьогодні. Вони вічні, а значить, осягнення хореографічного мистецтва як відбиття внутрішнього світу кожної людини не повинно залежати від сучасного стану культури у світі та престижності її освоєння сьогодні.

Слідом за загальнотеоретичним та практичним оглядом того, що відбувається в хореографічному навчанні хотілося б розглянути деякі програми з хореографії, рекомендовані Міністерством освіти, варіативність використання яких також явище неоднозначне, тому що принципово різні розуміння результату хореографрічного навчання, відсутність єдиної стратегії в розвитку художнього мислення учнів, з одного боку, та у зв'язку з цим 
відсутність єдиної методології та єдності формується мислення у майбутніх педагогів-хореографів, з іншого боку, - ось лише деякі, але досить суттєві недоліки ситуації, що склалися.

Безсумнівним плюсом програм є трактування уроку хореографії «як уроку мистецтва, морально-естетичним стрижнем якого $є$ художньо-педагогічна ідея ...вічні теми мистецтва: добро і зло, любов і ненависть, життя і смерть, материнство, захист Вітчизни тощо» [3].

Автор виходить з необхідності «методологічного осмислення процесу пізнання хореографічного мистецтва» та виводить три концептуальні ідеї:

- хореографрія показує життя на філософрському рівні, звідси хореографія $\epsilon$ зображенням діалектики життя та ії̈ змісту - це людський досвід моральноестетичного оцінювання світу, вираженого в художньо-пластичних образах специфічною для даного мистецтва мовою;

- пізнання хореографрічного мистецтва здійснюється, як самостійна діяльність школярів по виявленню того, як реальне, що набуває у нашому баченні риси звичності, повсякденності, буденності та іншого, стає художнім;

- діяльність викладача хореографрії - це не робота по «трансляції» знань, умінь і навичок в їх загальноприйнятому, традиційному розумінні, а його творчість в організації діяльності школярів у розвитку в них художньо-творчих здібностей.

Спираючись на аналіз педагогічної та методичної літератури, який був зроблений В. М. Ніловим у галузі мистецької освіти та виховання школярів засобами хореографрічного мистецтва, можна виділити три основні напрямки:

- перший - художнє виховання розвивається та функціонує на базі поза шкільних установ культури - клубів, Будинків і Палаців культури.

- другий напрямок мистецької освіти розвивається на базі хореографрічних відділень (освітнього рівня) Дитячих музичних шкіл (ДМШ) і Дитячих шкіл мистецтв (ДШМ), а також окремих самостійних Дитячих хореографрічних та балетних шкіл (ДХШ).

- третій напрямок художнього виховання засобами хореографрічного мистецтва в умовах загальноосвітньої школи $€-$ позакласна робота або факультативна за бажанням (для цього в програмі школи закладено години для різних гуртків самодіяльної творчості) [2].

Аналізуючи педагогічну ситуацію в сучасній школі, можна відзначити, що в останні роки спостерігається тенденція до розширення використання хореографічного мистецтва в загальноосвітніх школах. Виникла не тільки потреба в систематичній цілеспрямованій хореографічній освіті на базі загальноосвітніх шкіл при взаємодії з установами культури, але намітилися тенденції формування та розвитку нової структури хореографічного напрямку освіти в навчально-виховному процесі загальноосвітньої школи.

Провівши даний екскурс по сучасному хореографрічному освітньому простору, ми можемо зробити висновок, що:

- високий рівень технократизму та дидактизму, присутній у багатьох педагогічних системах, концепціях й працях, демонструє відсутність теоретичного мислення та діалектичної логіки в їх основі;

- поняття цілісності педагогічного процесу на уроці хореографії береться лише в вузько формальному сенсі слова, а наукові підходи, на які посилаються сучасні автори, мають, по суті, одностороннє та поверхневе осмислення; 
- проблема творчого розвитку учня на уроці хореографрії нині не вирішена системно, в цілісності всіх елементів й рушійних сил даного процесу. Як наслідок усього перерахованого, урок хореографії не розглядається авторами сучасних методик як цілісний процес, через категорії змісту та форми, в якому вміст мистецтва, художня ідея твору, а значить, і уроку в цілому, диктували б творчі завдання уроку, визначали б фрорму його побудови.

\section{Список використаних джерел:}

1. Кульневич, С. В. (2004). Современныц̆ урок [научнопрактич. пособие для учителей, методистов, руководителей учебных заведений, студентов пед. учеб. заведений, слушателей ИПК]. Ростов н/Д: «Учитель».

2. Нилов, В.Н. (2010). Современное состояние хореографического искусства в художественном образовании детей и молодежи. Москва.

3. Биковська, Т. В., Шкура Г. А. (Eds.). (2016). Навчальні програми з позашкільної освіти художньо-естетичного напряму. Київ: УДЦПО.

4. Тарасов, Н. И. (1971). Классический танец. Школа мужского исполнительства. Москва. «Искусство».

\section{ЗАСТОСУВАННЯ МІЖКУЛЬТУРНОГО ПІДХОДУ У ПРОЦЕСІ ВИВЧЕННЯ ІНОЗЕМНОÏ МОВИ}

Попсуй Анатолій Васильович
викладач кафедри іноземних мов
Національний університет «Чернігівський колегіум» імені Т.Г.Шевченка
УКРАїнА

Усвідомлення культурних особливостей різних країн, готовність до взаємодії у полікультурному просторі $€$ важливою ознакою реформування системи вищої педагогічної освіти. 3 часом істотного значення набуває конкурентоспроможність майбутніх фрахівців, що виявляється у здатності до виконання ролі культурного посередника між рідною культурою та іноземною, відображає уміння успішно долати міжкультурні непорозуміння та конфрліктні ситуації. Цьому сприяє застосування міжкультурного підходу, зокрема під час вивчення іноземної мови, який, на основі усвідомлення загальнолюдських цінностей, забезпечує розкриття національної самобутності різних культур.

До проблеми підготовки майбутніх фахівців на основі міжкультурного підходу звертались М. Бахтін, Л. Вітковський, Ю. Габермас, К. Кляне, А. Краузе, Т. Левовицький, Є. Нікіторович, Т. Тодорова та інші. Особливості полікультурної освіти досліджували Р. Агадуллін, Л. Гончаренко, Я. Гулецька, В. Кузьменко, Н. Мельник, В. Осадчий, Л. Пуховська, І. Родигіна, С. Сисоєва, Н. Шульга та інші.

Міжкультурний підхід у загальному значенні пов'язується із проблемою розуміння: себе та інших осіб, стосунків між людиною та суспільством, загальнолюдських цінностей, відмінностей між народами та їхніми культурами. У науковій літературі сутність означеного підходу зумовлюється визначенням 
самого поняття «міжкультурний» на відмінну від інших термінів, основою яких $€$ поняття «культура», таких як «соціокультурний», «крос-культурний», «транс культурний», «мультикультурний», «полікультурний».

«У рамках міжкультурного підходу,-як зазначено у Загальнноєвропейських рекомендаціях з мовної освіти,-головною метою навчання мови $€$ : сприяння розвитку цілісної особистості того, хто вивчає мови, та його самоусвідомлення шляхом збагачення досвіду, розуміння відмінностей між іншими мовами та культурами» [1]. Цей підхід має багато спільного із соціокультурним. Однак, на відміну від останнього, за словами М.Байрам, цей підхід характеризує ще й відносини та обмін між культурами [2].

Застосування міжкультурного підходу зумовлюється положенням щодо взаємодії споріднених або схожих культур. Так, у ході вивчення іноземної мови студенти вчаться аналізувати культурні явища, порівнювати їх, виявляти схожі елементи, спільні та відмінні цінності. Як наслідок, у студентів зникають риси етноцентризму, фрормується толерантність, міжкультурна компетентність.

Навчання іноземних мов на основі міжкультурного підходу потребує відповідної організації навчального процесу. А. Томас підкреслював, що міжкультурне навчання означає не тільки розуміння системи ціннісних орієнтацій чужої культури, а й відображає ціннісні уявлення власного народу; це процес розвитку, виникнення, розуміння й прийняття їх відмінностей [3].

Отже, застосування міжкультурного підходу у процесі вивчення іноземної мови - це не просто ознайомлення студентів з іншою культурою, але й культурний розвиток особистості. Його впровадження зумовлюється організацією міжкультурного навчання, у ході якого здійснюється осмислення відмінності та подібності різних культур.

\section{Список використаних джерел:}

1. Загальноєвропейські рекомендації з мовної освіти: вивчення, викладання, оцінювання (2003). Київ: Видавництво Ленвит.

2. Byram, M. \& Zarate, G. (1996). Defining and Assesing Intercultural Competence Some Principles and Proposals for the European Context. Language Teaching (10). 239-243.

3. Thomas, A. (1988). Interkultureslles Lernen im Schuleraustausch. Saarbrücken. Fort Lauderdale: Verlag Breitenbacy. 


\section{ЗМІНИ В ОРГАНІЗАЦІЇ НАВЧАЛЬНОГО ПРОЦЕСУ ТРУДОВІЙ ШКОЛІ УКРАЇНИ НА ПОЧАТКУ 20-РОКІВ ХХ СТОЛІТТЯ}

Великдан Юлія Віталіївна

старший викладач кафедри теорії та методики технологічної освіти та комп'ютерної графріки ДВНЗ «Переяслав- Хмельницький ДПУ ім. Г.Сковороди»

УКРAÏHA

Нова система освіти, що розпочала формуватися після громадянської війни в УРСР у 20-і роки, ставила перед школою нові завдання, бо саме в ті роки в боротьбі за новий суспільний лад величезна роль належить школі і вчителю. Отже, завдання школи полягало в тому, щоб озброювати учнів міцними знаннями основ наук, виробити у них цілісний матеріалістичний світогляд, виховувати їх у дусі комуністичної моралі, підготувати до життя та до праці. Саме цим і займався Наркомос УРСР, що своїми діями та рішеннями в різний період постійно змінював хід процесу навчання в школах.

Нову українську систему освіти більшовики намагалися будувати за російським зразком. Беручи за основу «Положення про єдину трудову школу», що діяло в Радянській Росії, вони прийняли у травні 1919 р. «Положення про єдину трудову школу УРСР», яке включала в себе загальні положення про школу, основні принципи шкільної праці, основні принципи самоуправління єдиної трудової школи, порядок і умови шкільної праці та розділ «шкільні працівники» який регламентує статус шкільних працівників, зокрема директора та учителів [1].

Отже, потребуючи конкретних змін у школі та зважаючи на реалії суспільного життя того часу, нарком освіти Г.Ф. Гринько, розробив проект нової системи освіти, в ії основі лежало соціальне виховання дітей, а робота всіх освітніх і виховних закладів будувалася за трудовим принципом і за своїми завданнями та змістом утворювала єдину систему професійної освіти: дитячий садок, дитячий будинок, комуна та колонія в новому шкільному проекті призначалися для дітей від 4 до 8 років і мали статус дошкільного закладу соціального виховання; для дітей віком від 8 до 15 років були запропоновані концентри (I концентр 4-річний - з 8 до 12 років, II концентр 3-річний - 312 до 15 років); молодь, віком від 15 до 18 років мали можливість навчатися в професійних школах; та найвищою ланкою в освіті були вищі навчальні заклади (технікум, інститут, академія).

Варто відзначити, що на початку $1920-x$ років на навчально-виховний процес негативно впливало те, що шкільні заклади ще не мали стабільних навчальних планів і програм. Учителям доводилося працювати без єдиного, обов'язкового для всіх шкіл навчального плану. Починаючи з 1921-го р., Народний Комісаріат Освіти, щорічно видавав спеціальні «Порадники соціального виховання», в яких вміщувалися матеріали про школу і виховання в Україні, положення і статути дитячих установ, програмні матеріали та інше, що 3 кожним роком доповнювався, та удосконалювався. «Порадники соціального виховання» були головним джерелом за допомогою яких у вигляді 
загальних вказівок здійснювалося загальне регулювання навчально-виховного процессу, а також вчителі брали настанови стосовно впровадження комплексного навчання.

Як результат подальшої праці Наркомосу над удосконаленням комплексної системи навчання, в 1925 р. вийшов новий «Порадник соціального виховання». В Пораднику чітко були подані плани проведення комплексних тем. Тематика їх була спрямована на вивчення трудової діяльності й мала на меті підготувати учнів до конкретної сільськогосподарської та промислової праці. А також, порадник містив Методологічний лист Держнаукметодкому в якому описувалося про нормалізацію життя установ соціального виховання. Треба підкреслити, що для сільських та міських трудових шкіл, організація навчально-виховного шкільного року значно відрізнялась, на що і звертається увага. Отже, до 1925 року, для міський шкіл 1-й триместер триває з 1 вересня по 15 грудня, 2-й - з 1 січня по 1 квітня, 3-й - з 15 квіня по 1 вересня, а от для сільських шкіл: 1-й триместер триває з 15 вересня по 15 грудня, 2-й - з 1 січня по 15 квітня та 3-й - з 1 травня по 1 вересня. При цьому регулярні заняття в 3му триместрі закінчуються: в міських школах 20-го червня, а в сільських школах - 1-го червня, і це складає для міської школи 8 місяців і 20 днів, а для сільської школи тільки 7 місяців і 15 днів. Маємо різницю, яка в зв'язку з тим, що школи на селі далеко відстали в своїй структурі від шкіл міста, досить негативно відбивається на кінцевому ефекті перебування учня в школі. Тому було за потребу, зрівняти навчальний рік міських та сільських шкіл. Для цього краще навчальний рік сільських шкіл установити в терміни, що припадають і для міських шкіл. Ці строки навчання треба точно виконувати. Треба пам'ятати, що вже настав час рішучої й упертої боротьби за максимально довгий рік, і що 240 робочих днів на рік для всякої трудової школи повинно стати за звичайну й непохитну норму виробки [2].

Враховуючи головну особливість 20-х років XX ст., створення нової системи освіти, слід зазначити, що зміст шкільної освіти зазнав істотних змін, і це дуже вплинуло на організацію саме навчально-виховного процесу в школі. Характерним для навчальних планів та програм того періоду було запровадження комплексної системи. Навчальні дисципліни не вивчалися окремо, а об'єднувалися в комплекси. «Порадники соціального виховання», що виходили у світ під керівництвом Наркомосу, були навчально-методичним джерелом запровадження комплексного навчання в шкільних закладах освіти Радянської України.

\section{Список використаних джерел:}

1. Великдан, Ю. В., \& Марков, Д. Ф. (2018). Організація навчального процесу в трудовій школі України на початку 20-х років XX століття. Young, 58(6).

2. Мушка, О.В. (2010). Реформування наркомосом змісту освіти в шкільних закладах України періоду 1920-1930 рр. Вісник Житомирського державного університету імені Івана Франка, (53), 164-168. 


\title{
ІНДИВІДУАЛЬНИЙ ПІДХІД ДО СТУДЕНТА ЯК ЗАПОРУКА ЕФЕКТИВНОЇ ПІДГОТОВКИ СТУДЕНТІВ ЗАКЛАДІВ ВИЩОЇ ОСВІТИ
}

\begin{abstract}
Полець Марія-Вікторія Ярославівна викладач циклової комісії «Апаратних засобів інформатизації» Відокремлений структурний підрозділ - Коледж телекомунікацій та комп'ютерних технологій Національного університету «Львівська політехніка»

УКРАÏHA
\end{abstract}

Одним з найважливіших стратегічних завдань на сьогоднішньому етапі інтеграції Україні в єдиний світовий інформаційний простір є запровадження нових IT-технологій та якісна підготовка майбутніх фахівців для вдосконалення і втілення в життя Концепції Національної програми інформатизації [5].

Згідно ЗУ «Про освіту», освіта є державним пріоритетом, що забезпечує інноваційний, соціально-економічний і культурний розвиток суспільства, а її фінансування $\epsilon$ інвестицією в людський потенціал, сталий розвиток суспільства і держави. Державна політика у сфері освіти формується і реалізується на основі наукових досліджень, міжнародних зобов'язань, вітчизняного та іноземного досвіду з урахуванням прогнозів, статистичних даних та індикаторів розвитку 3 метою задоволення потреб людини та суспільства [4].

Для успішного соціального розвитку суспільства заклади освіти мають готувати висококваліфікованих фахівців, які відповідатимуть вимогам інформаційного суспільства, будуть конкурентно-спроможними на сучасному ринку праці, ефективно діятимуть у професійному та соціальному середовищах та будуть здатні навчатися протягом життя.

На даний час існує проблема підготовки креативної особистості, високоінтелектуального фахівця, здібного до творчості, об'єктивно пов'язана зі створенням «творчого» освітнього середовища, активізацією пізнавальної діяльності студента у закладах вищої освіти. В умовах сучасної освіти, коли центром освітньої діяльності $€$ дитина, а головним завданням кожного викладача - формування всебічно розвиненої гармонійної особистості, все більш актуальним стає застосування сучасних технологій навчання, що враховують індивідуальні особливості кожного студента. Також набуває популярності дистанційне навчання, що робить освіту відкритою, загальнодоступною, а засоби навчання більш функціональними та еорективними.

В навчально-виховному процесі закладів вищої освіти об'єктом педагогічної діяльності викладача $€$ студент. Однією 3 характерних особливостей навчально-виховного процесу у закладів вищої освіти (3ВО) $\epsilon$ те, що результати взаємодії в системі «викладач-студент», а також кінцеві результати діяльності вищого навчального закладу, а саме якість одержаних в 
процесі навчання знань та вмінь, сформованих компетентностей випускників 3ВО, рівень їх виховання, а також їх професійна конкурентоспроможність на ринку праці напряму залежать від того, наскільки добре викладач вміє застосовувати індивідуальний підхід до студентів. знає індивідуальні особливості своїх студентів і враховує їх при організації навчально-виховного процесу.

Автори «Креативної педагогіки і психології» О.В. Морозов та Д.В. Чернілевський зазначають: «Викладачеві необхідно володіти вмінням комплексно планувати задачі навчання і виховання, розвиваючи здібності студентів на основі вивчення їх реальних можливостей, виокремлювати головне, суттєве в змісті, правильно добирати методи, засоби і форми організації навчання і виховання, здійснювати диференційований підхід до студентів, створювати студентам необхідні умови для навчання, вміло використовувати вибраний варіант навчального процесу, оперативно його коректуючи при необхідності» [6].

Для того щоб правильно організувати навчально-виховний процес та максимально ефективно підібрати педагогічну технологію необхідно розглянути психологічні особливості студентського або старшого юнацького віку.

Поняття студентського або старшого юнацького віку виділене у сімдесятих роках двадцятого століття і охоплює вікову групу 17-23 років.

В результаті проведення дослідження наукових праць варто виділити думку А. С. Власенка, який визначає, що «студентство - це особлива соціальна група, яка формується з різних соціальних утворень суспільства і характеризується особливими умовами життя, праці, побуту, особливою суспільною поведінкою і психологією, для якої набуття знань і підготовка себе для майбутньої роботи у суспільному виробництві, науці і культурі $\epsilon$ головним і здебільшого єдиним заняттям» [2].

Також вагомий внесок в дослідження студентства зробив Б. Г. Анан'єв, який вважає: «Перетворення мотивації, всієї системи ціннісних орієнтацій, з одного боку, інтенсивне формування спеціальних здібностей у зв'язку 3 професіоналізацією, з іншого - виділяють цей вік як центральний період формування характеру та інтелекту» [8].

На думку Л. В. Власенко «Найголовніший прийом виховання - це сприйняття людини такою, якою вона є, без прямих оцінок і повчань» [3]. О.М.Балакирова та О. О. Яременко [1] водночас вважають, що тільки у такому випадку зберігатиметься у вихователя контакт з вихованцем, який є запорукою їх продуктивної взаємодії. При цьому головним завданням вихователя $€$ надання своєму вихованцю доступу до широкого спектру варіантів вибору, які не доступні власне особистості через брак ії життєвого досвіду, недостатності знань і незвіданості всього багатства культури.

Важливою для роботи є думка Ю. А. Самаріна [9], який вважає, що саме в період студентства людина вчиться самостійності, пробує свої сили в різних життєвих напрямках, оприділяється 3 майбутньою професією, отримує необхідні для майбутнього життя навички і на їх основі формує та відстоює власні судження, світогляд, погляди на життя. Формування особистості проходить досить складно і супроводжується рядом суперечностей та 
труднощів, котрі необхідно враховувати при організації навчально-виховного процесу.

3 праць В. Л. Ортинського та М. М. Фіцули випливає, що «суперечності при формуванні особистості мають соціально-психологічний характер: з одного боку, розвиток інтелектуальних, фізичних сил студента, а з іншого обмеженість часу, економічних можливостей для задоволення потреб тощо» [7; 10]. Інтереси студентів здебільшого стосуються їх майбутньої професії, а самостійність в цьому віці набуває нового рівня: життя в гуртожитку, раціональне використання особистих коштів і вільного часу. Спосіб організації навчання, відпочинку і побуту студентів переважно залежать від кола їхнього спілкування: друзів, групи, їх організованості, цінностей, моральних якостей, норм поведінки. Отже, неформальні лідери в групах значною мірою впливають на роботу всієї навчальної та виховної системи роботи у ЗВО. Саме тому важливим є завдання налагодження хороших стосунків і коректної взаємодії студентів у групі, що буде сприяти успішному навчально-виховному процесу загалом по навчальному закладі.

Соціолог В. Шубкін називає вік від 17 до 25 років доленосним періодом у житті людини. Інтенсивні пошуки поклику, вибір пріоритету, перехід від книжних романтичних уявлень до зіткнення з реальними інститутами, професійне самовизначення, працевлаштування, створення сім'ї, інтенсивне дозрівання особистості; досягнення стабільності та піку більшості психічних фуннкцій (розвитку уваги 22-24 роки, розвитку пам'яті 23,24 років; розвитку мислення від 20-22 до 25 років), переоцінка цінностей і мотивації поведінки, посилення свідомих мотивів поведінки, формування якостей характеру та інтелекту [9].

Досліджуючи та аналізуючи роботу Т. І. Туркота [9] можна виділити наступні напрями налагодження хороших стосунків і коректної взаємодії студентів під час навчально-виховного процесу:

1) забезпечення у вищому навчальному закладі необхідних психологопедагогічних умов для здійснення адаптації та входу студентів як у навчальновиховний процес так і соціальне життя закладу освіти;

2) надання постійної психологічної підтримки студентам і забезпечення хорошого психологічного клімату в групах;

3) надання студентам допомоги у формуванні їх взаємин з іншими;

4) формування взаємоповаги та правильних, рівних відносин між студентами і викладачами;

5) забезпечення всіх необхідних умов для реалізації творчого потенціалу студентів;

Основним завданням викладача $є$ допомогти студенту сформувати власну особистість, отримати всі потрібні знання та навички. В своїй педагогічній роботі він має врахувати індивідуальні особливості студентів, їх сприйняття, розуміння, здатність до запам'ятовування, природні завдатки.

Аналізуючи роботи В. Л. Ортинського та М. М. Фіцули [7; 10], можна зробити висновок, що при організації роботи, викладач повинен також врахувати, що студенти, вступивши до ЗВО, в процесі адаптації та пристосуванні до нових умов зустрічаються з рядом перешкод: соціально-психологічними (нові умови життя, новий колектив, новий режим роботи, несформованість взаємин в групі, нове місто, самостійне життя); професійними (погана орієнтація в професійній 
складовій навчального процесу; відсутність організаторських навичок тощо), дидактичними (новий формат навчання, нова методика викладання, невміння самостійно працювати тощо).

Важливими завданнями на шляху реалізації окресленої проблеми $є$ забезпечення кваліфікованої допомоги в організації й плануванні самостійної навчальної роботи; озброєння студентів першого курсу знаннями про інноваційну культуру навчальної праці, освоєння сучасних освітніх технологій; ознайомлення їх з особливостями методики самостійної роботи з кожної навчальної дисципліни; активізація розумової діяльності студентів на заняттях; забезпечення розуміння змісту навчальних занять як умови логічного аналізу отриманої інфоомації; консультації (групові й індивідуальні) з інноваційної культури сучасної навчальної праці; фрормування потреби до самовдосконалення; забезпечення контактності викладачів і студентів [11].

Студентський вік $€$ найсприятливішим періодом для формування і розвитку інтелекту. В цьому віці провідною $є$ здатність людини до активної пізнавальної та навчальної діяльності. В структурі інтелекту виділяють дві сторони: інтелект як здатність до пізнання навколишнього світу та як засіб адаптації відповідно до отриманих раніше знань. Отже, інтелект людини являє собою один із найскладніших характеристик психіки особистості.

Структура інтелекту включає систему процесів пізнання, через які людина знайомиться з навколишнім світом. Обробка інформації відбувається за таким алгоритмом: навколишні подразники впливають на органи чуття, результатом чого $є$ виникнення нервових імпульсів, які надсилаються до головного мозку, обробляються, створюють відчуття, а далі формують повний образ, який порівнюється з образами збереженими в пам'яті. Таким чином відбувається процес розпізнання, а потім при аналізі актуальної інформації та порівняння 3 попереднім досвідом наступає осмислення та відбувається розуміння отриманої інформації і лише тоді створюється поняття. Тож основна робота повинна спрямовуватися на сприйняття і розуміння необхідної інформації.

Це ще раз доводить необхідність активізації самостійного мислення при роботі студента. Уявлення відображають окремі зовнішні властивості, характеристики та ознаки явищ i предметів вивчення, а поняття характеризують їх суть, передумови виникнення та прогнозовані наслідки.

Також поширеною серед науковців думкою $€$ те, що інтелект людини - це її здібності до обробки та перетворення інформації. Також $є$ більш оптимальна версія, яка говорить, що в структурі інтелекту необхідно виділити здібності критичного мислення, аналізу ситуації, прийняття рішень, а також здатність адаптації та здійснення самоаналізу і самоконтролю.

Академік М.К. Тутушкіна в своїх психологічних дослідженнях, виділила поняття «загального інтелекту», який складається 3 вербального i невербального інтелектів і переважно вимірюється показником IQ, який дозволяє порівняти рівень інтелектуальних можливостей 3 середніми значеннями показників, характерними для його віку чи професії.

Функціонування вербального інтелекту здійснюється в словесно-логічній формі і переважно опирається на знання. Він показує здатність людини до аналізу і синтезу отриманої інформації. 
Функціонування невербального інтелекту базується на розвитку наочнодієвого мислення, спираючись на візуальні образи і просторове уявлення.

Структура інтелекту залежить від віку, індивідуальних особливостей особистості, освіти та роду занять. Таким чином, в результаті проведених соціологами досліджень було виявлено, що в студентів технічних спеціальностей порівняно переважає невербальний інтелект, тоді коли в студентів спеціальностей гуманітарного спрямування більш розвинутий вербальний інтелект. Також дослідження інтелекту показали, що найбільшого успіху досягають ті, хто має розвинений і невербальний і вербальний інтелект.

В сучасній психології поняття «креативність» характеризує властивість створювати щось нове, здатність до творчого мислення і вивчається незалежно від інтелекту.

Діяльність викладача має забезпечити вдосконалення організації навчально-виховного процесу на основі індивідуального підходу з метою підвищення мотивації, інтересу та самостійності студентів в процесі засвоєння нових знань, виробленні вмінь та навиків, а також творчого застосування їх на практиці.

Проведені дослідження показують важливість застосування індивідуального підходу до особистості студента в навчальному процесі, який ґрунтується на врахуванні його індивідуальних психологічних рис, інтересів, задатків, здібностей, а також мотивації.

Отже, на даний час існує проблема при підготовці студентів ЗВО як креативних високоінтелектуальних особистостей, фахівців, здатних критично мислити, що володіють навичками необхідними для саморозвитку. Рішенням даної проблеми є застосування індивідуального підходу до студентів, який сприятиме створенню всіх необхідних умов для їхнього навчання та активізації їхньої пізнавальної діяльності.

Як було досліджено, від фахової спрямованості 3ВО залежить і переважаючий тип інтелекту студентів, а найбільших успіхів досягають ті, хто має розвинений і вербальний та невербальний і інтелект. На основі даних досліджень можна зробити висновок, що важливим $€$ всебічний розвиток інтелекту студентів, а не лише згідно вузької спеціалізації ЗВО.

Для вирішення цього завдання i ефективної підготовки майбутніх спеціалістів у навчально-виховному процесі необхідно застосовувати нові педагогічні технології, які в більшості передбачають використання високоефективних технічних засобів (комп'ютери, мультимедійні комплекси, електронні та web-pесурси, спеціальне програмне забезпечення), що дають можливість створювати дистанційне інтерактивне інформаційно-комунікаційне середовище і використовувати як традиційні, так і інноваційні педагогічні технології, ґрунтовані на індивідуальному підході.

Отже, якість навчання та ступінь інтеграції в навчально-виховний процес нових освітніх технологій буде напряму залежати від матеріально-технічного забезпечення вищого навчального закладу та кваліфікації викладачів.

щоб здійснити різносторонній аналіз проблеми викладання у ЗВО розглянемо проблему, давши відповіді на запитання: що $є ?$ що треба? Як реалізувати? 
$114 \bullet$ Problèmes et perspectives d'introduction de la recherche scientifique innovante $\bullet$ Volume 4

Що $€$ ? Існує проблема при підготовці студентів ЗВО як креативних високоінтелектуальних особистостей, фахівців, здатних критично мислити, що володіють навичками необхідними для саморозвитку.

Що треба? Для вирішення цієї проблеми і успішної підготовки майбутніх спеціалістів у навчальному процесі необхідно застосовувати індивідуальний підхід до студентів та нові педагогічні технології, з використанням дистанційних інтерактивних технологій, які не лише відносяться до інновацій, а вже стають новим освітнім стандартом. Використання дистанційних інтерактивних методів навчання створює нові можливості для пошуку фрорм і методів роботи, для виходу викладача на новий професійний рівень, для навчання разом 3 студентами, а результатом $€$ зростання інтересу студентів, позитивної зміни у ставленні студентів до викладача, зміни атмосфери в колективі групи.

Важливу роль відіграють високоефективні технічні засоби, що дають можливість створювати дистанційне інтерактивне інформаційно-комунікаційне середовище й використовувати як традиційні, так і інноваційні педагогічні технології, що базуються на індивідуальному підході.

Як реалізувати? Широкі можливості сучасних педагогічних технології надають можливість викладачу вільно використовувати їх багатогранність. Також збільшуються вимоги до викладача, який має бути порадником для студента, а також повинен постійно творчо розвиватись, бути обізнаним в підлітковій психології, вміти застосовувати на своїх заняттях сучасні IКТ, які зроблять заняття сучасним і цікавим. Щоб забезпечити розвиток особистості в процесі навчання в умовах особистісно-орієнтованої освіти доцільно поєднувати різні типи навчання, створюючи студентам умови, необхідні для розкриття їх творчого потенціалу.

\section{Список використаних джерел:}

1. Балакірова, О. М. \& Яременко, О. О. (1996). Проблеми соціального розвитку молоді на сучасному етапі. Молодь: стан, проблеми, шляхи розв'язання, (5), 231-256.

2. Власенко, А. С. (1971). Некоторые вопросы воспитания советского студенчества на современном этапе: ученые записки. Москва.

3. Власенко, Л. В. (2001). Концепція соціально-психологічного супроводу студентів вищих навчальних закладів. Зб. наук. праць Інституту психології ім. Г. С. Костюка АПН України (Т. IV; Ч. 2.; с. 54-61). Київ, Україна.

4. Про концепцію Національної програми інформатизації (Закон України), № 75/98-ВР від 11.08.2013p. Вилучено з http://zakon.rada.gov.ua/laws/show/75/98.

5. Про освіту (Закон України), № 2145-VIII від 05.09.2017p. Вилучено 3 http://zakon3.rada.gov.ua/laws/show/2145-19.

6. Морозов, А. В. \& Чернилевский, Д. В. (2004). Креативная педагогика и психология (2-е изд., испр. и доп.). Москва: Академический Проект.

7. Ортинський, В. Л. (2009). Педагогіка вищої школи. Київ: Центр учбової літератури.

8. Ананьева, Б. Г. \& Кузьмина, Н.В.(ред.). (1974). Современные психолого-педагогические проблемы высшей школы. Ленинград.

9. Туркот, Т. І. (2011). Педагогіка вищої школи: навчальний посібник для студентів вищих навчальних закладів. Київ: Кондор.

10. Фіцула, М. М. (2006). Педагогіка вищої школи. Київ: «Академвидав».

11. Чорний, Г. М. \& Ястреб, М. П. (2008). Організація навчально-виховного процесу у ВНЗ. Київ: НУБіП України. 


\section{LES NOTES}




\section{$\Lambda \mathrm{O} \mathrm{O} \mathrm{O}$}

COLLECTION DE PAPIERS SCIENTIFIQUES

\section{SUR LES MATÉRIAUX DE LA CONFÉRENCE SCIENTIFIQUE ET PRATIQUE INTERNATIONALE «PROBLÈMES ET PERSPECTIVES D'INTRODUCTION DE LA RECHERCHE SCIENTIFIQUE INNOVANTE» 20 novembre $2019 \cdot$ Bruxelles, Belgique}

\section{VOLUME 4}

Ukrainien, russe, français et anglais

Les matériaux sont imprimés dans le texte de l'auteur Le comité organisateur ne partage pas toujours la position des auteurs Pour l'exactitude de ce matériel, les auteurs portent la responsabilité

Signé pour impression le 29.11.2019. Format $60 \times 84 / 16$.

Papier offset. Arial type. Impression numérique

Feuilles imprimées conditionnées 6,74 .

Un tirage de 100 exemplaires.

Imprimé à partir de la mise en page originale finie.

Coordonnées du comité d'organisation:

21037, Ukraine, Vinnytsia, st. Zodchih, 18, bureau 81

Plateforme scientifique européenne

Téléphones: +38 098 1948380; +38098 1956755

E-mail: info@ukrlogos.in.ua

www.ukrlogos.in.ua | www.ojs.ukrlogos.in.ua 